Danielle Ayub de Barros Guerrieri Pinheiro

ESTUDO DO POTENCIAL MIOGÊNICO DAS CÉLULAS TRONCO MESENQUIMAIS E EMBRIONÁRIAS NO MODELO MURINO DA DISTROFIA MUSCULAR DE DUCHENNE

São Paulo

2008 
Danielle Ayub de Barros Guerrieri Pinheiro

\section{ESTUDO DO POTENCIAL MIOGÊNICO DAS CÉLULAS TRONCO MESENQUIMAIS E EMBRIONÁRIAS NO MODELO MURINO DA DISTROFIA MUSCULAR DE DUCHENNE}

Dissertação apresentada ao Instituto de Biociências da Universidade de São Paulo, para a obtenção do Título de Mestre em Ciências, na Área de Biologia/Genética.

Orientador(a): $\operatorname{Prof}^{\mathrm{a}} \operatorname{Dr}^{\mathrm{a}}$ Mariz Vainzof

São Paulo

2008 


\section{FICHA CATALOGRÁFICA}

\section{Ayub-Guerrieri, Danielle}

Estudo do potencial miogênico das células tronco mesenquimais e embrionárias no modelo murino da Distrofia Muscular de Duchenne / Danielle Ayub de Barros Guerrieri Pinheiro - São Paulo: D. AyubGuerrieri, 2008.

114 p.: il.

Dissertação (Mestrado) - Instituto de Biociências, Universidade de São Paulo. Departamento de Genética e Biologia Evolutiva, 2008.

1. Distrofia Muscular 2. Distrofina 3. Terapia Celular 4. Células tronco

I. Universidade de São Paulo, Instituto de Biociências, Departamento de Genética e Biologia Evolutiva.

\section{COMISSÃO JULGADORA}

$\operatorname{Prof}(a) . \operatorname{Dr}(a)$.

Prof(a). Dr(a).

$\operatorname{Prof}(a) . \operatorname{Dr}(a)$.

Orientador(a) 


\section{DEDICATÓRIA}

Ao meu amado marido, Max, pelo amor, apoio, cumplicidade e compreensão em todos os momentos da nossa vida.

Ao meu querido filhinho Benjinho por me esperar todos os dias em casa pacientemente.

Aos meus pais, Ricardo e Nélia, que sempre torceram pela minha realização profissional. 


\section{EPÍGRAFE}

"Posso ter defeitos, viver ansioso e ficar irritado algumas vezes, mas não esqueço de que minha vida é a maior empresa do mundo. E que posso evitar que ela vá à falência. Ser feliz é reconhecer que vale a pena viver, apesar de todos os desafios, incompreensões e períodos de crise. Ser feliz é deixar de ser vítima dos problemas e se tornar um autor da própria história. É atravessar desertos fora de si, mas ser capaz de encontrar um oásis no recôndito da sua alma. É agradecer a Deus a cada manhã pelo milagre da vida. Ser feliz é não ter medo dos próprios sentimentos.

É saber falar de si mesmo. É ter coragem para ouvir um não. É ter segurança para receber uma crítica, mesmo que injusta.

Pedras no caminho?

Guardo todas, um dia vou construir um castelo..."

Fernando Pessoa 
A realização deste trabalho foi possível graças ao apoio e ajuda de várias pessoas. Gostaria de agradecer, em especial:

À minha orientadora, Dra Mariz Vainzof, por ter me recebido em seu laboratório, me ensinado tudo que eu sei até hoje de Biologia Molecular e que se tornou quase uma mãe pra $\operatorname{mim}$;

Às Dras Mayana Zatz e Maria Rita Passos-Bueno, pelo exemplo de pesquisadoras e pela convivência harmoniosa;

À Dra Lygia da Veiga Pereira pelos seus preciosos ensinamentos e pela ajuda nos experimentos;

Às Dras Claudia Madalena Cabrera Mori e Silvia Maria Gomes Massironi por nos ajudar a estabelecer as colônias de camundongos em nosso biotério.

À minha querida amiga Poliana que sempre esteve do meu lado nos momentos mais alegres, mas também nos mais tristes, nunca deixando de me dar apoio;

Aos meus outros amigos de laboratório: Vanessa, Lydia, Martinha, Paula, Dinorah, Lucas, Wagner, André e Adriano, que sempre me ajudaram nas horas difíceis.

Aos meus ex-companheiros de laboratório: Vica, Paty, Fer, Bruno e Telma que me incentivaram quando eu estava apenas começando e me ajudaram a dar os primeiros passos na genética.

Aos colegas dos outros laboratórios: Natássia, Tatiana, Eder, Viviane, Mari, Kitty, Fernando Lojudice, Fanga, Daniela que sempre colaboraram conosco;

Ao pessoal do CEGH: Sr Valter, Márcia, Fernando, Neide, Roberto, Lílian, Martha, Vanessa, Kátia, Camila, Kelly por sempre estarem ajudando quando possível;

À minha irmã, aos meus avôs e aos meus sogros, que sempre me apoiaram e torceram por $\operatorname{mim}$;

À Universidade de São Paulo onde desenvolvi meu mestrado, especialmente ao Centro de Estudos do Genoma Humano, obrigada pela formação científica e acadêmica.

À FAPESP e CNPq pelo apoio financeiro.

\section{Muito obrigada a todos!}


RESUMO 
Neste trabalho verificou-se o potencial terapêutico de células tronco murinas mesenquimais e embrionárias no tratamento da Distrofia Muscular de Duchenne. A sua capacidade de regenerar o músculo distrófico foi averiguada in vitro e in vivo, no modelo murino $m d x$. Em cultura, constatou-se que as células tronco mesenquimais de medula óssea (MSC) têm a capacidade de fusão e diferenciação espontânea em fibras musculares, independentemente de estímulo de outros tipos celulares ou de indução in vitro à miogênese. Quando injetadas no músculo afetado, células MSC expressando a proteína GFP só foram detectadas, no máximo, após 3 dias, sugerindo a sua eliminação após este período. Quando injetadas via sistêmica, as células MSC eGFP não foram direcionadas corretamente para o músculo distrófico. Estas células também foram eliminadas em camundongos selvagens da linhagem $F V B$, sugerindo que a proteína GFP poderia ser a responsável pela sua rejeição. As células tronco embrionárias (ESlinhagem 129) também demonstraram capacidade miogênica in vitro. Quando injetadas no músculo de camundongos $m d x$ imunossuprimidos, provocaram reação inflamatória muito intensa e grande aumento local da massa muscular. Essa nova estrutura, no entanto, não continha células com características de fibras musculares. Nos camundongos injetados sistemicamente, as células ES permaneceram na região de sua introdução na cauda, demonstrando pouca distribuição e disseminação para o músculo lesado. A análise de marcadores polimórficos específicos da linhagem das células ES permitiu a identificação das mesmas na concentração mínima de 30\%. Este resultado indica que a hipertrofia observada no músculo do camundongo injetado foi causada, pelo menos, por esta quantidade de células. Estudos adicionais são necessários para aumentar o potencial terapêutico destas células em modelos distróficos murinos. 
We investigated therapeutic potential of murine mesenchymal and embryonic stem cells in the treatment of Duchenne Muscular Dystrophy. Their ability to regenerate the dystrophic muscle was studied in vitro and in vivo, in the murine mdx model. In culture, bone marrow mesenchymal stem cells (MSC) showed the capacity to fuse and to spontaneously differentiate into muscle fibers, independently of stimulation by contact with other cell types or exposure to miogenic factors in vitro. When injected into affected muscles, MSC expressing GFP protein were detected after 3 days at most, suggesting their elimination after this period. When injected in the systemic via, MSC eGFP were not properly directed to the dystrophic muscle. These cells were also eliminated in the wild strain FVB mice, suggesting that GFP protein could be responsible for this rejection. The embryonic stem cells (ES-line 129) also showed a good miogenic capacity in vitro. When injected into the muscle of immunosuppressed mdx mice, they caused very intense inflammatory reaction and a significant increase of its leg muscle mass. However, this new tissue did not contain cells with muscle fibers characteristics. In systemically injected mice, the ES cells remained in the region of introduction in the tail, showing poor distribution and dissemination into the injured muscle. Specific ES cell line polymorphic markers analysis identified a concentration of at least $30 \%$. This result indicates that muscle hypertrophy observed in injected mice was caused by at least this amount of cells. Additional studies are necessary to increase the therapeutic potential of these cells in dystrophic murine models. 
Tabela 1: Camundongos injetados local e sistemicamente com MSC eGFP, células ES e EB nos experimento de implantação in vivo.

Tabela 2: Pares de primers com seqüências específicas presentes no gene GFP e nas regiões polimórficas dos camundongos

Tabela 3: Pares de primers com sequiências específicas presente nos genes MYF5, MyoD, Miostatina e Distrofina.

Tabela 4: Camundongo injetado intramuscularmente com células MSC eGFP no experimento 1 42

Tabela 5: Camundongos injetados intramuscularmente com células MSC eGFP no experimento 2 . 46

Tabela 6: Camundongos injetados intramuscularmente com células MSC eGFP de quarta passagem no experimento 3 .

Tabela 7: Camundongos injetados sistemicamente com células MSC eGFP de quarta passagem no experimento 4 .

Tabela 8: Animais injetados intramuscularmente com células MSC eGFP de quarta passagem no experimento 5 ...... 55

Tabela 9: Camundongos injetados local e sistemicamente com células MSC eGFP quarta passagem no experimento 6 . 56

Tabela 10: Camundongos injetados localmente com células MSC eGFP de quarta passagem no experimento 7 . 
Tabela 11: Camundongos não imunossuprimidos injetados local e sistemicamente com células ES no experimento 8, e avaliação quantitativa da presença de células ES marcadas, através da verificação de coloração vermelha nos corte histológicos dos músculos e tecidos dos camundongos injetados.

Tabela 12: Camundongos imunossuprimidos injetados local e sistemicamente com células ES no experimento 8, e avaliação quantitativa da presença de células ES marcadas, através da verificação de coloração vermelha nos corte histológicos dos músculos e tecidos dos camundongos injetados 65

Tabela 13: Camundongos imunossuprimidos injetados local e sistemicamente com células originárias dos EB no experimento 9. 


\section{LISTA DE ILUSTRACCÕES}


Figura 1: Complexo de proteínas associadas à distrofina e doenças relacionadas. .02

Figura 2: Esquema mostrando a organização dos domínios da proteína distrofina......

Figura 3: Imunohistoquímica visualizando a distrofina em controles normais e em pacientes com Distrofia Muscular de Becker (BMD) e Distrofia Muscular de Duchenne (DMD) (Aumento X 200)....

Figura 4: Diferenciação das ES pelo método de hanging drop.

Figura 5: Isolamento e cultura de células mesenquimais de camundongo C57black6 (a) com 4 dias, (b) com 7 dias e (c) com 10 dias após sua adesão à superfície do frasco de cultura, mostrando o enriquecimento de células mesenquimais com o passar do tempo (Aumento X 100) 35

Figura 6: Cultura de células mesenquimais de camundongos eGFP. (a) visualização das células mesenquimais à luz visível e (b) no filtro para a fluorescência verde (Aumento X $100)$. 36

Figura 7: Reação de imunofluorescência de lâminas com células MSC com os diferentes anticorpos de membrana, mostrando marcação negativa para CD34 e CD45 e marcação positiva para CD13, CD29 e CD44 (Aumento X 200).

Figura 8: Cultura de células mesenquimais de camundongo eGFP em meio de cultura suplementado com $20 \%$ de Soro Fetal Bovino, em que se verificou a ocorrência de fusão celular espontânea ((a) Aumento X 100 e (b) Aumento X 200). 
Figura 9: Reação de RT-PCR com primers específicos para cDNA de distrofina em (1) mioblastos $\mathrm{C} 2 \mathrm{C} 12$, (2) células $\mathrm{MSC}$ em processo de diferenciação espontânea, (3) diferenciação induzida com hidrocortisona, (4) de diferenciação induzida com IL-6, (5) Músculo de camundongo C57black6.

Figura 10: Co-cultura de mioblastos de camundongo $m d x$ com células mesenquimais de camundongo eGFP, com ocorrência de fusão celular (Aumento X 100) 40

Figura 11: Western Blotting para a proteína distrofina das células do experimento de cultura. 41

Figura 12: Coloração de hematoxilina-eosina em cortes histológicos do músculo gastrocnêmio de (a) camundongo normal, (b) camundongo $m d x$ controle e (c) camundongo $m d x$ injetado com células MSC (Aumento X 200) 42

Figura 13: Reação de imunofluorescência com o anticorpo anti-distrofina em cortes histológicos do músculo gastrocnêmio de (a) controle positivo - camundongo C57black6, (b) camundongo $m d x$ não injetado, (c) camundongo $m d x$ injetado (Aumento X 200)........ 43

Figura 14: Observação direta do corte histológico de tecido muscular do camundongo $m d x$ injetado com células marcadas com GFP, mostrando forte autofluorescência observada no tecido (Aumento X 200). 44

Figura 15: Western Blotting para a tentativa de detecção da proteína distrofina, em músculos gastrocnêmio injetado do camundongo do experimento 1 45

Figura 16: Visualização de cortes histológicos do músculo dos camundongos $m d x$ injetados no experimento 2. (a) visualização do corte do tecido muscular à luz visível e (b) visualização do mesmo campo de possíveis células eGFP (Aumento X 400). 46 
Figura 17: Reação de imunofluorescência com o anticorpo anti-GFP em cortes histológicos de músculos injetados dos camundongos do experimento 2. (a) camundongo $F V B$ eGFP em filtro de fluorescência verde, (b) reação do camundongo $F V B$ eGFP com o anticorpo, (c) camundongo $m d x$ injetado em filtro de fluorescência verde, (d) camundongo $m d x$ injetado reagido com a anticorpo anti-GFP (Aumento X 200)

Figura 18: Western Blotting para rastreamento da proteína GFP nos músculos dos camundongos injetados no experimento 2

Figura 19: Reação de imunofluorescência de cortes histológicos de músculos dos camundongos injetados no experimento 3 com o anticorpo anti-distrofina. (a) controle positivo de camundongo, (b) camundongo $m d x$ não injetado, (c) camundongo $m d x$ injetado (Aumento X 200)......

Figura 20: Western Blotting para a proteína distrofina nos extratos dos músculos dos camundongos injetados no experimento 3

Figura 21: Western Blotting para a proteína distrofina nos extratos dos músculos dos camundongos injetados no experimento 4

Figura 22: Reação de PCR do DNA dos diferentes tecidos dos camundongos do experimento 4, assim como seu controle positivo (células MSC eGFP), amplificados com primers específicos do gene eGFP.

Figura 23: Reação de PCR do DNA dos músculos injetados e controles de camundongos do experimento 5, assim como seu controle positivo (células MSC eGFP), amplificados com primers específicos do gene eGFP. 55

Figura 24: Reação de PCR do DNA dos músculos injetados e controles dos camundongos do experimento 6, assim como seu controle positivo (células MSC eGFP), amplificados com primers específicos do gene eGFP. 
Figura 25: Reação de PCR do DNA dos músculos injetados e controles de camundongos do experimento 7, assim como seu controle positivo (células MSC eGFP), amplificados com primers específicos do gene eGFP. 59

Figura 26: Cultura de células tronco embrionárias, em que (f) representa o FEEDER e (ES) são as células tronco embrionárias.

Figura 27: Western Blotting para a proteína distrofina das células embrionárias em possível processo de diferenciação espontânea por contato.

Figura 28: Cultura de células tronco embrionárias, em que (f) representa o FEEDER e (ES) são as células tronco embrionárias.

Figura 29: ES coradas em vermelho.

Figura 30: Comparação de tamanho entre o músculo gastrocnêmio do camundongo $M d x 37$ injetado com células ES (pata esquerda) e o seu músculo controle (pata direita). 66

Figura 31: Músculo gastrocnêmio injetado do camundongo $\mathrm{Mdx}$ 37, mostrando focos marcados de vermelho, o que pode significar a presença das células injetadas (Aumento $\mathrm{X}$ 200). 67

Figura 32: Corte histológico do músculo gastrocnêmio injetado com células ES dos camundongos (a) $M d x 28$ e (b) $M d x$ 29, mostrando a diferença entre a presença de coloração vermelha (Aumento X 200). 67

Figura 33: Corte histológico da cauda do camundongo $M d x$ 39, injetado sistemicamente com células ES (Aumento X 200). 68 
Figura 34: Corte histológico de músculo gastrocnêmio injetado do camundongo $M d x 37$, em que se observa a presença de focos de degeneraão intensa (Aumento X 100) 68

Figura 35: Tecido hipercelular presente no corte histológico do músculo gastrocnêmio injetado do camundongo de $M d x 37$ (Aumento X 400). 69

Figura 36: Reação de imunofluorescência para a proteína distrofina em corte histológico do músculo gastrocnêmio injetado do camundongo $M d x 37$, mostrando a presença de uma possível fibra muscular em formação (Aumento X 200). 70

Figura 37: Reação de imunofluorescência para a proteína miosina fetal de cortes histológicos do músculo do camundongo $M d x 37$, mostrando ausência de marcação (Aumento X 200)

Figura 38: Reação de imunofluorescência para proteína miosina fetal em cortes histológicos de músculos de (a) camundongo $m d x$ não injetado e (b) camundongo $M d x 37$ (Aumento X 200) 71

Figura 39: Western Blotting para a proteína distrofina nos extratos dos músculos dos camundongos não imunossuprimidos injetados local e sistemicamente com células ES no experimento 8 72

Figura 40: Western Blotting para a proteína distrofina nos extratos dos músculos dos camundongos imunossuprimidos injetados local e sistemicamente com células ES no experimento 8 . 
Figura 41: Reação de PCR do DNA dos músculos injetados e controles de camundongos não imunossuprimidos injetados local e sistemicamente com células ES no experimento 8, amplificados com primers de marcadores específicos de cada linhagem de camundongo. A banda de menor peso molecular (121 pb) representa o DNA do camundongo $m d x$, enquanto a banda de maior peso molecular (142 pb) representa o DNA das células ES.

Figura 42: Reação de PCR do DNA dos músculos injetados e controles de camundongos imunossuprimidos injetados local e sistemicamente com células ES no experimento 8, amplificados com primers de marcadores específicos de cada linhagem de camundongo. A banda de menor peso molecular (121 pb) representa o DNA do camundongo $m d x$, enquanto a banda de maior peso molecular (142 pb) representa o DNA das células ES.

Figura 43: Reação de PCR da mistura de quantidades pré-estabelecidas do DNA dos músculos de camundongos $m d x$ não injetados com DNA de células ES, amplificados com primers de marcadores específicos de cada linhagem, mostrando que se conseguiu identificar até $10 \%$ de células depois de injetadas no músculo de camundongos $m d x$, pela presença das 3 bandas relativas aos marcadores 75

Figura 44: (a) Mioblastos (Aumento X 100) e (b) miotubos gerados a partir da prédiferenciação de células ES, marcados com a proteína desmina (Aumento X 400). 76

Figura 45: Reação de imunofluorescência para a proteína distrofina em cortes histológicos do músculo gastrocnêmio do camundongo $M d x 43$ (Aumento X 200). 78

Figura 46: Western Blotting para a proteína distrofina nos extratos dos músculos dos camundongos imunossuprimidos injetados local e sistemicamente com EB no experimento 9. 
Figura 47: Reação de PCR do DNA dos músculos injetados e controles de camundongos imunossuprimidos injetados local e sistemicamente com EB no experimento 9, amplificados com primers de marcadores específicos de cada linhagem de camundongo. A banda de menor peso molecular (121 pb) representa o DNA do camundongo $m d x$, enquanto a banda de maior peso molecular (142 pb) representa o DNA das células ES. 80 


\section{LISTA DE ABREVIATURAS E SIGLAS}


$\boldsymbol{\alpha - M E M : ~ M i n i m u m ~ E s s e n t i a l ~ M e d i u m ~ E a g l e ~ A l p h a ~ M o d i f i c a t i o n ~}$

AFS: Células tronco derivadas de líquido aminiótico

C57black6 : Camundongo normal

cDNA: DNA codificante total

C-terminal: Região carboxi terminal

Cy3: Cianina 3

DGC: Complexo de Glicoproteínas associadas a distrofina

DMB: Distrofia Muscular de Becker

DMD: Distrofia Muscular de Duchenne

DMEM: Dubecco's Modified Eagles Medium

DMP: Distrofia Muscular Progressiva

DMSO: Dimetil sulfóxido

DNA: Ácido desoxirribonucléico

dNTP: Dinucleotídeo

EB: Corpos embrióides

ES: Células tronco embrionárias

FEEDER: Fibroblastos embrionários de camundongos inativados mitoticamente

FGF: Fator de Crescimento de Fibroblastos

FITC: Fluoresceína isotiocianato

GDF-8: Miostatina

GFP: Proteína fluorescente verde

HEPES: N-2-hidroxietilpiperazina-N'-2-etanosulfônico

hESC: Células tronco embrionárias humanas 
HGF: Fator de Crescimento de Hepatócitos

HLH: Família protéica helix-loop-helix

ICM: Massa de células interna

IGF-I e IGF-II: Fatores de Crescimento Insulina-like I e II

IL-6: Interleucina 6

LIF: Fator Inibidor de Leucemia

Mdx: Camundongo distrófico

MPC: Células precursoras musculares

MSC: Células tronco mesenquimais

Myf4: Miogenina

MyoD: Antígeno de Diferenciação Miogênico

N-terminal: Região amino terminal

Pax7: Paired box transcription factor 7

PBS: Solução tampão fosfato

PCR: Reação da polimerase em cadeia

RNA: Ácido ribonucléico

SFB: Soro fetal bovino

TBE: Tampão Tris-borato EDTA

TGF $\beta$ : Fator de Crescimento Transformador $\beta$

Xp21: Braço curto do cromossomo X 
SUMÁRIO 
1.6 Fatores de transcrição e fatores de crescimento envolvidos no processo de diferenciação e regeneração muscular...

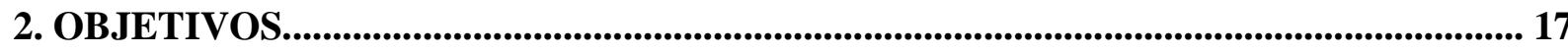

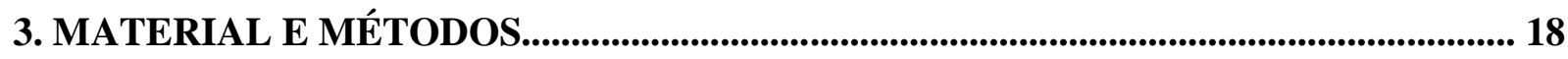

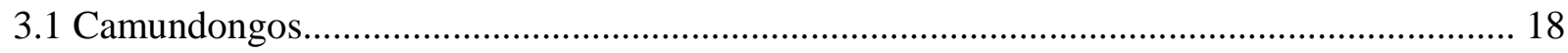

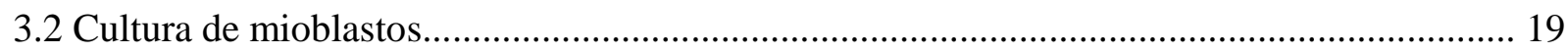

3.3 Isolamento e cultura de células mesenquimais de camundongos eGFP................................ 20

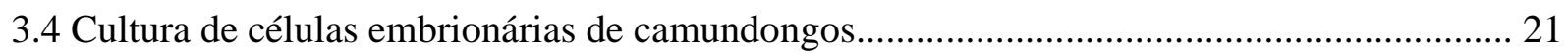


3.4.3 Pré-diferenciação das células embrionárias de camundongos 22

3.5 Implantação de mioblastos e de células tronco mesenquimais e embrionárias em camundongos $m d x$.

3.6 Co-cultura de células tronco mesenquimais e embrionárias com mioblastos de camundongos $m d x$ e experimentos de diferenciação in vitro.

3.7 Congelamento e processamento das biópsias de diferentes tecidos. 28

3.8 Caracterização e detecção das células e de proteínas relacionadas com a diferenciação miogênica.

3.8.1 Tentativa de visualização das células recém-injetadas 29

3.8.2 Coloração de Hematoxilina-Eosina 29

3.8.3 Imunohistoquímica em biópsia muscular

3.8.4 Western blotting

3.8.5 Análise do DNA genômico.

3.8.5.1 Gene eGFP 32

3.8.6 Extração de RNA de músculo e de células. 33

4. RESULTADOS. 35

4.1 Experimentos com células tronco mesenquimais. 35

4.1.1 Estabelecimento da metodologia de isolamento e cultura de células tronco mesenquimais de camundongos 35

4.1.2 Caracterização das MSC 36 
4.1.3 Experimentos in vitro com células tronco mesenquimais 37

4.1.3.1 Experimentos de diferenciação espontânea das células MSC em mioblastos.... 37

4.1.3.2 Experimentos de diferenciação induzida das células MSC em mioblastos 38

4.1.3.3 Experimentos de co-cultura de células MSC com mioblastos de camundongos $m d x$.

4.1.3.4 Análise por Western Blotting da proteína distrofina nos experimentos de cultura com células MSC 40

4.1.4 Experimentos in vivo: Implantação de células MSC em camundongos 42

4.1.3.1 Experimento 1: Injeção intramuscular de células MSC eGFP-Análise após 4 semanas

4.1.3.2 Experimento 2 - Injeção intramuscular de células MSC eGFP - Análise após 1 dia e 1 semana.

4.1.3.3 Experimento 3 - Injeção intramuscular de células MSC eGFP de quarta passagem - Análise após 4 semanas.

4.1.3.4 Experimento 4 - Injeção sistêmica de células MSC eGFP - Análise após 4 semanas 51

4.1.3.5 Experimento 5 - Injeção intramuscular de células MSC eGFP - Análise após curto período. 54

4.1.3.6 Experimento 6 - Injeções intramuscular e sistêmica de células MSC eGFP associadas à imunossupressão - Análise após diferentes períodos. 56

4.1.3.7 Experimento 7 - Avaliação do micro-ambiente distrófico - Injeções intramusculares de células MSC eGFP em diferentes linhagens de camundongos normais. 
4.2 Experimentos com células tronco embrionárias. 60

4.2.1 Estabelecimento da metodologia de cultivo de células tronco embrionárias de camundongos 60

4.2.2 Experimentos in vitro com células tronco embrionárias 60

4.2.2.1 Experimentos de diferenciação das células: Análise por Western blotting para a proteína distrofina.

4.2.2.2 Experimentos de diferenciação das células ES e de co-cultura com mioblastos de camundongos $m d x$ : Análise por PCR para proteínas de linhagem muscular.. 61

4.2.3 Experimentos in vivo: Implantação de células tronco embrionárias em camundongos $m d x$. 63

4.2.3.1 Experimento 8 - Injeções intramusculares e sistêmicas de células tronco embrionárias.

4.2.3.2 Experimento 9 - Injeções intramusculares e sistêmicas de células de Corpos Embrióides. 75

5. DISCUSSÃO. 81

6. CONCLUSÕES. 98 
1. INTRODUCÃ̃O 


\subsection{Distrofia Muscular Xp21}

As distrofias musculares progressivas (DMPs) constituem um grupo heterogêneo de doenças genéticas caracterizadas por uma degeneração progressiva e irreversível da musculatura esquelética, e que têm sido objeto de muitas pesquisas. Mais de trinta formas distintas de distrofias já são conhecidas, cuja herança pode ser autossômica dominante, recessiva ou ligada ao X (ZATZ et al., 2000). Em biópsia muscular, os achados histológicos característicos consistem em variação no tamanho das fibras, infiltração do músculo por tecido conjuntivo e adiposo, e áreas de necrose, provocado por repetidos ciclos de regeneração e degeneração muscular com uma eventual falha em sua regeneração. (GARDER-MEDWIN, 1980; BUSHBY \& BECKMANN, 1995; ZATZ et al., 2000).

Dentre as diferentes miopatias, a Distrofia Muscular de Duchenne (DMD), de herança recessiva ligada ao cromossomo $\mathrm{X}$, é a mais comum, com uma incidência de $1 \mathrm{em}$ cada 3000 nascimentos de sexo masculino. Já a Distrofia Muscular de Becker (BMD), alélica à DMD, é cerca de 10 vezes mais rara. A diferença entre essas duas formas está na idade de início e velocidade de progressão (ZATZ et al., 2001). Na DMD, os sinais clínicos iniciam-se entre 3 e 5 anos de idade, com quedas freqüentes, dificuldades para subir escadas, correr e levantar do chão. O confinamento em cadeira de rodas se dá até os 12 anos de idade e os afetados raramente sobrevivem após a terceira década. Já na BMD, os sintomas iniciam-se, em geral, na segunda década: os afetados sempre andam após os 16 anos, e a velocidade de progressão é extremamente variável.

O gene responsável pela DMD/BMD localiza-se no braço curto do cromossomo X, na banda Xp21 (ZATZ et al., 1981; VERELLEN-DUMOULIN et al., 1984; FRANCKE et al., 1985). Após a sua localização que levou à clonagem em 1987 (HOFFMAN et al., 
1987), descobriu-se que o produto do gene DMD/DMB é uma proteína de 427-kDa, denominada distrofina, localizada no citoesqueleto das fibras musculares esqueléticas e cardíacas. A função da distrofina seria a de manter a estabilidade da membrana da célula muscular, garantindo, assim, o tráfego de informações através da membrana da célula muscular (HOFFMAN \& DRESSMAN, 2001). Estudos de solubilização da distrofina a partir de frações do sarcolema mostraram que a esta proteína está associada a um complexo de proteínas e glicoproteínas da membrana sarcolemal denominado Complexo Glicoproteína-Distrofina (DGC) (ERVASTI \& CAMPBELL, 1991), que também teriam um papel fundamental na manutenção da estrutura da fibra muscular e liga o citoesqueleto miofibrilar com a matriz extracelular. Mutações em outros componentes desse complexo podem acarretar no aparecimento de tipos diferentes de distrofias (ZATZ et al., 2001).

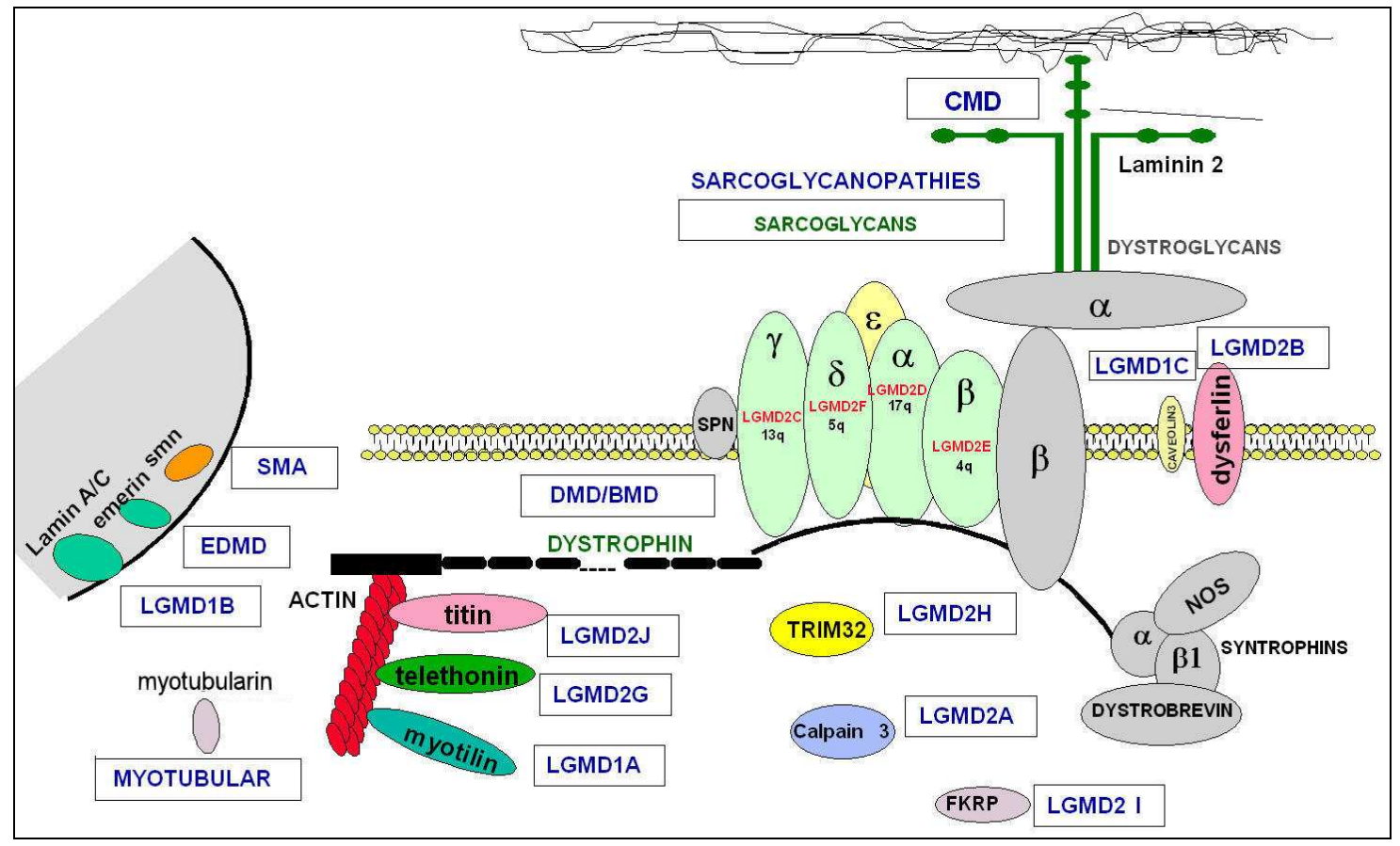

Figura 1: Complexo de Proteínas associadas à distrofina e doenças relacionadas (VAINZOF \& ZATZ, 2003). 


\subsection{A organização molecular da proteína Distrofina}

A distrofina é organizada em 4 domínios, estabelecidos de acordo com a sequiência da aminoácidos, homologia com outras proteínas e capacidade de ligação: uma região Nterminal, com homologia à $\alpha$-actinina, um domínio em bastão central (rod), um domínio rico em cisteína e um domínio C-terminal (BLAKE et al., 2002). A região N-terminal e o domínio rod se ligam ao citoesqueleto de actina. O domínio rod é composto por 24 unidades repetidas, corresponde a maior parte da proteína e é responsável pela sua flexibilidade. A porção rica em cisteína contém várias regiões, incluindo o domínio WW, que a separa do domínio rod, um sítio de ligação com a proteína à $\beta$-distroglicana, 2 domínios EF de ligação com o $\mathrm{Ca}^{2+}$ intracelular e o domínio $\mathrm{ZZ}$ de ligação de cátions metálicos divalentes como o $\mathrm{Zn}^{2+}$. Já o domínio C-terminal é composto por 2 cadeias polipeptídicas formando uma $\alpha$-hélice dobrada (denominada região $\mathrm{CC}$ ), tendo como funções unir a distrofina à distrobrevina e modular a interação entre a sintrofina e outras proteínas do DGC.

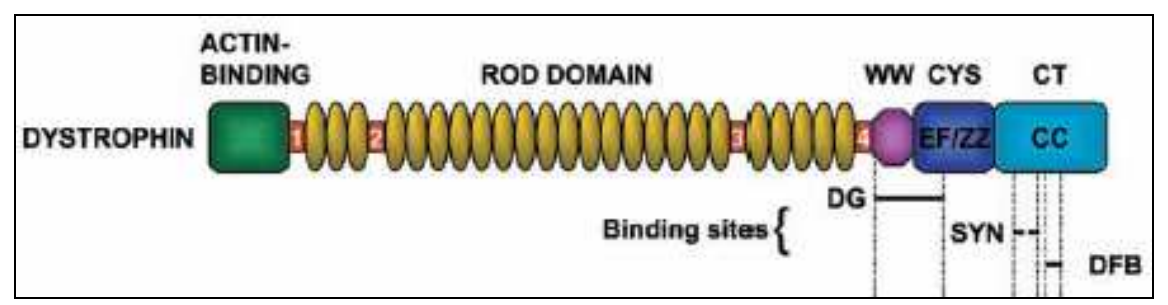

Figura 2: Esquema mostrando a organização dos domínios da proteína distrofina. 


\subsection{Mutações em DMD e BMD}

As mutações causadoras de DMD e BMD são deleções no gene da distrofina em cerca de $60 \%$ dos casos, duplicações em 5-6\% e mutações de ponto nos casos restantes (KOENIG et al.,1989). A grande maioria das mutações em pacientes com DMD resulta na completa ausência de distrofina, enquanto a presença de baixas quantidades dessa proteína é encontrada em casos de BMD (NAWROTZKI et al.,1996). Existe uma correlação entre as mutações no gene de DMD e o resultado fenotípico. Na BMD a deleção é em fase, o quadro de leitura do mRNA é mantido, e tem-se como resultado uma proteína quantitativamente reduzida ou deletada internamente, mas que continua parcialmente funcional. Já na DMD, a deleção cria uma mutação frameshift, onde o quadro de leitura não é mantido, e tem-se uma proteína gravemente truncada, rapidamente destruída pela célula.

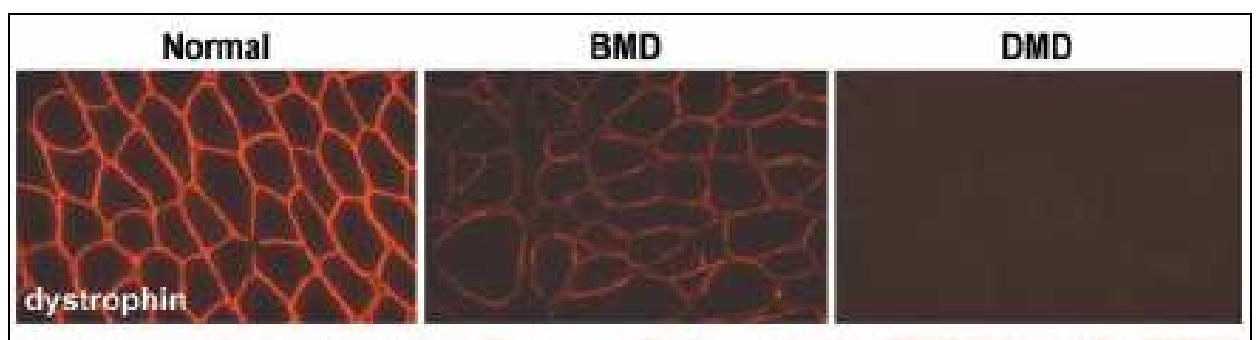

Figura 3: Imunohistoquímica visualizando a distrofina em controles normais e em pacientes com Distrofia Muscular de Becker (BMD) e Distrofia Muscular de Duchenne (DMD) (Aumento X 200).

\subsection{Modelos animais deficientes em distrofina}

O estudo de modelos animais deficientes em distrofina, como camundongos, cães e gatos, é crucial para ajudar no conhecimento de distrofias humanas progressivas e para a investigação de terapias experimentais. Cachorros exibem a doença de maneira muito mais 
rápida do que os humanos, enquanto gatos e camundongos mostram um quadro típico mais benigno.

O camundongo $m d x$ é o modelo natural da Distrofia Muscular de Duchenne, e consiste em uma ferramenta bastante utilizada em testes de funcionamento da proteína, assim como em possíveis formas de tratamento para DMD. Essa linhagem de camundongos é deficiente em distrofina devido a uma mutação de ponto no exon 23 do gene da distrofina, que forma um códon de parada prematura (BULFIELD et al., 1984). Como em pacientes com DMD, o músculo de camundongos $m d x$ é afetado por degeneração e necrose. Entretanto, o camundongo $m d x$ exibe um curso clínico mais brando (PASTORET \& SEBILLE, 1995). Além disso, a fraqueza muscular não é característica e o tempo de vida não é reduzido. Apesar de inicialmente as células satélites se replicarem para repor e regenerar a injúria, essas células tornam-se gradualmente escassas com a idade e o camundongo passa a demonstrar deterioração muscular (PASTORET \& SEBILLE, 1995; REIMANN et al., 2000). Ao nascer, as células satélites são responsáveis por $32 \%$ dos mionúcleos, com uma queda para menos de 5\% em adultos, a partir dos 2 meses de vida.

Esse camundongo também apresenta um grande número de fibras revertentes (23\%), que passam a sintetizar novamente de forma espontânea a distrofina. Como a presença natural destas fibras dificulta a análise de terapias que visam a expressão de distrofias, outros modelos murinos de DMD foram experimentalmente induzidos (DANKO et al., 1992). O mutante $m d x 4 c v$ é resultado de uma mutação nonsense no exon 53 da distrofina. Já o mutante $m d x 5 c v$ é resultado de uma transição A para T, gerando um splicing alterado e uma deleção de 53 pares de base no exon 10. Esse camundongo exibe uma taxa extremamente baixa $(<0,2 \%)$ de fibras revertentes. 


\subsection{Células satélites e o processo de degeneração-regeneração em DMD}

Músculos esqueléticos de mamíferos adultos exibem uma grande capacidade de se adaptarem a demandas, como crescimento e injúria. Os processos pelos quais essas adaptações ocorrem são atribuídos a uma pequena população de células que são residentes no músculo denominadas células satélites ou células precursoras miogênicas. Essas células são mononucleadas e localizam-se na periferia dos miotubos maduros, entre o sarcolema e a lâmina basal das fibras musculares. Sem nenhuma perturbação, essas células encontramse em um estado não proliferativo (quiescente). Entretanto, em resposta a um estímulo, seja uma injúria ou em resposta a uma demanda aumentada de trabalho, as células satélites tornam-se ativadas, proliferam e começam a expressar os marcadores miogênicos (células satélites que expressam marcadores miogênicos são também denominadas mioblastos). Por último, elas se fundem a fibras musculares já existentes ou fusionam-se para formar novas miofibras multinucleadas, em um processo que recapitula os eventos fundamentais do desenvolvimento muscular (HAWKE \& GARRY, 2001).

A população de células precursoras musculares pode suportar diversos ciclos de degeneração e regeneração, entretanto, essa capacidade é finita. A exaustão do pool de células precursoras é um importante fator que contribui com a deterioração muscular gradual observada em pacientes com distrofias musculares. A ausência de distrofina no músculo resulta em uma deficiência secundária nos componentes do DGC (OHLENDIECK \& CAMPBELL, 1991) e, como conseqüência, instabilidade desse complexo, as fibras musculares ficam mais susceptíveis ao estresse mecânico causado pela contração muscular, levando ao processo de degeneração em pacientes com DMD. 
O processo de regeneração é caracterizado por duas fases: a fase degenerativa e a fase regenerativa (CHARGÉ \& RUDNICKI, 2004). A morte das fibras musculares ou de fragmentos de fibras seja por apoptose ou necrose, ocorre em conseqüência dos defeitos bioquímicos primários causados pela patogenia. A morte de células ativas varia dependendo do músculo que é examinado, da idade do paciente e da espécie que manifesta a doença. Esse evento é marcado pelo rompimento do sarcolema das miofibrilas, resultando em um aumento na permeabilidade refletido por uma elevação do nível sérico de proteínas musculares como a creatina quinase, que é geralmente restrita ao citosol da célula muscular. Nessa fase ocorre a ativação de células mononucleadas, principalmente células inflamatórias e células satélites. A regeneração muscular que segue a morte celular reflete as mudanças secundárias, caracterizadas pela substituição do músculo por tecido adiposo ou conectivo, logo após a perda de sua capacidade regenerativa.

\subsection{Fatores de transcrição e fatores de crescimento envolvidos no processo de diferenciação e regeneração muscular}

A regeneração muscular é um processo complexo que requer uma modulação coordenada entre as células satélites, fatores de crescimento, citocinas, respostas inflamatórias, componentes vasculares e da matriz extracelular (GOETSCH et al., 2003). Os fatores de transcrição miogênicos pertencem à família protéica helix-loop-helix (HLH) e têm um papel fundamental na miogênese e na regeneração: as células onde eles não são expressos não se diferenciam em músculo (SEALE \& RUDNICKI, 2000).

O MyoD (Antígeno de Diferenciação Miogênico - Myf3) atua na regulação da expressão de genes em tempos diferentes durante a miogênese e é essencial no reparo de lesões musculares, uma vez que participa da ativação das células satélite no intervalo de 6 
horas depois da injúria (HAWKE \& GARRY, 2001). O Myf5 está estruturalmente relacionado ao $M y o D$ e também atua na determinação dos mioblastos durante o desenvolvimento embrionário, auxiliando na proliferação das células satélites (HAWKE \& GARRY, 2001). Não há nenhuma patologia associada ao $M y f 5$ e ao $M y o D$, porém a sua expressão pode estar aumentada em DMD/DMB e em miopatias inflamatórias. Quando a inativação do gene do $M y o D$ é induzida em camundongos, observa-se atraso no desenvolvimento da musculatura dos membros. Entretanto, quando há inibição do $M y o D$ concomitante com inibição do $M y f 5$, há ausência total de mioblastos e não há formação de tecido muscular (MUNTONI et al., 2002).

A miogenina (Myf4) é um fator essencial para a diferenciação de células totipotentes em músculo. Estudos realizados com culturas de diversos tipos celulares mostram que estes se diferenciam em músculo quando expostos à miogenina. Um experimento realizado com camundongos mostrou que mutações no gene da miogenina causam morte imediatamente após o nascimento e os animais apresentam diminuição muito grande de massa muscular e perda da linha Z do sarcômero (MUNTONI et al., 2002).

Outro fator de transcrição que influencia a atividade das células satélites é o $\operatorname{Pax} 7$ (paired box transcription factor 7), expresso em células quiescentes e em proliferação. A presença de mutações neste gene causa ausência total de progenitores miogênicos no músculo (HAWKE \& GARRY, 2001; MUNTONI et al., 2002). Essas descobertas suportam a hipótese de que o Pax7 é essencial para a especificação das células satélites.

Os Fatores de Crescimento Insulina-like I e II (IGF-I e IGF-II) participam da regulação da regeneração, pois aumentam a proliferação, a diferenciação e a fusão das células satélites in vitro, provocando aumento da massa muscular e da quantidade de 
células (HAWKE \& GARRY, 2001; MUNTONI et al., 2002; CHARGÉ \& RUDNICKI, 2004).

O Fator de Crescimento de Hepatócitos $(H G F)$ aumenta a proliferação de células precursoras miogênicas induzindo a ativação de células quiescentes, assim como diminui a sua diferenciação, inibindo os fatores regulatórios da miogênese (CHARGÉ \& RUDNICKI, 2004).

O Fator de Crescimento de Fibroblastos $(F G F)$ tem 9 isoformas (FGF-1 a $F G F-9)$. Os $F G F-1,-2,-4,-6$ e -9 estimulam a proliferação celular, enquanto FGF-5, -7 e -8 não têm atividade miogênica. Além do aumento da atividade proliferativa, essa família de fatores também atenua a diferenciação das miofibras (HAWKE \& GARRY, 2001).

O Fator de Crescimento Transformador $\beta(T G F \beta)$ é uma importante citosina regulatória do crescimento celular (CHARGÉ \& RUDNICKI, 2004). A miostatina (GDF-8) é um dos membros desta superfamília e sua atuação inibe a proliferação e a diferenciação muscular, pois silencia a ativação dos fatores de transcrição (HAWKE \& GARRY, 2001). Desta forma, ela determina a massa muscular esquelética e atua como regulador negativo do crescimento muscular (MUNTONI et al., 2002).

A Família de citosinas Interleucina 6 é composta pelo Fator Inibidor de Leucemia (LIF) e Interleucina 6 (IL-6). O LIF aumenta o processo regenerativo e a IL-6 promova a degradação do tecido necrosado, sincroniza o ciclo celular das células satélite e induz a apoptose logo após a injúria, porém não aumenta a proliferação (HAWKE \& GARRY, 2001).

Muitos outros fatores estão envolvidos com a regulação das células satélites no músculo esquelético adulto, como Óxido nítrico, Fator de Crescimento Derivado de 
Plaquetas, Fator de Crescimento derivado de Endotélio e testosterona (HAWKE \& GARRY, 2001).

Portanto, a regulação das células satélites é orquestrada por numerosos fatores, coordenados temporalmente e dependentes de concentração adequada durante a regeneração do músculo.

\subsection{As células tronco}

As células tronco são definidas por duas propriedades. Primeiro, elas são células que podem se dividir indefinidamente, produzindo populações idênticas à anterior. Além disso, elas também podem sofrer divisão assimétrica e dar origem a duas linhagens de células, uma idêntica à parental e outra que contém diferentes instruções genéticas e que se caracterizam por uma reduzida capacidade proliferativa e um potencial de desenvolvimento menor que da célula original. Normalmente, as células tronco são conhecidas como células progenitoras ou precursoras, comprometidas com a produção de uma ou poucas células diferenciadas (FISCHBACH \& FISCHBACH, 2004).

\subsubsection{Tipos de células tronco}

Podem-se encontrar vários tipos de células tronco nos diversos estágios da embriogênese (FISCHBACH \& FISCHBACH, 2004). Logo após a fertilização, o zigoto se divide diversas vezes até formar uma bola compacta de células chamada mórula. Essas células são totipotentes, ou seja, cada uma é capaz de dar origem a todos os tipos de células e tecidos diferenciados, inclusive tecidos extraembrionários. Conforme a mórula percorre o oviduto, as células continuam a proliferar até formar uma esfera oca chamada blastocisto, com uma massa de células interna (ICM), que será fonte de células tronco embrionárias. 
Essas são pluripotentes, ou seja, são comprometidas em se diferenciarem em todos os tipos de células e tecidos, com exceção de tecidos extraembrionários. No momento da implantação, o blastocisto se invagina (gastrulação) resultando na formação das três camadas germinativas do embrião: ectoderme, endoderme e mesoderme. As células tronco encontram-se presentes em cada uma dessas camadas. Essas células podem dar origem a vários tipos celulares, com espectro mais restrito que as derivadas do blastocisto, descritas, então, como multipotentes.

Células tronco embrionárias manipuladas em laboratórios são derivadas do grupo de células internas do blastocisto e são consideradas pluripotentes pois são capazes de se diferenciarem em qualquer tecido in vivo e in vitro. Causas éticas e políticas a respeito dessa linhagem de células de humanos, entretanto, tornam seu uso ainda difícil.

Por outro lado, células tronco adultas são células indiferenciadas intrínsecas a vários tecidos diferenciados do corpo e são capazes de manter, gerar e repor células diferenciadas, apesar de não haver evidências de que elas são pluripotentes. Essas células podem ser encontradas em vários tecidos incluindo medula óssea, sistema nervoso central, epitélio, tecido adiposo, músculo cardíaco e músculo esquelético.

\subsubsection{O uso terapêutico das células tronco}

Apesar dos grandes avanços no campo da genética e biologia molecular, não existe ainda uma cura efetiva para qualquer uma das distrofias musculares. Há, no entanto, muitas técnicas experimentais em desenvolvimento, incluindo terapia gênica, terapia farmacológica e, principalmente, terapia celular (HOFFMAN \& DRESSMAN, 2001). Nesse último caso, como o processo de regeneração muscular em pacientes distróficos exaure o número de células satélites residentes, e todas as células existentes possuem a 
mesma mutação que leva à doença, torna-se necessário o recrutamento de progenitores miogênicos indiferenciados adicionais de outras fontes. Por isso, o transplante de diferentes tipos celulares como mioblastos, fibroblastos e, mais atualmente, as células tronco, têm emergido como um tratamento promissor para o reparo das miofibras distróficas (CHAKKALAKAL et al., 2005). As células tronco estão entre o amplo espectro de células que podem ser utilizadas em transplante celular, que podem resultar em ativação do processo de regeneração muscular. Isso se daria através da fusão destas células com as células originais do receptor, levando a incorporação do núcleo normal, capaz de expressar a proteína originalmente deficiente, formando um sincício mosaico de fibras musculares multinucleadas.

Pesquisas a respeito de células tronco embrionárias (ES) nas últimas duas décadas resultaram numa melhor compreensão dos processos moleculares envolvidos durante a sua diferenciação. Sob certas condições in vitro, essas células podem proliferar indefinidamente e são capazes de originar quase todas as linhagens celulares de diferentes funções, como cardiomiócitos, progenitores hematopoiéticos, adipócitos, hepatócitos e tecido muscular, dentre outros (ROHWEDEL et al., 1994; DOSS et al., 2004). Essas propriedades impulsionaram o interesse no estudo de suas aplicações terapêuticas, onde o objetivo mais imediato é reparar ou reconstruir o tecido afetado por várias doenças degenerativas humanas associadas com perda de função celular, como já comprovado no infarto do miocárdio, diabetes e Doença de Parkinson (DOSS et al., 2004). Trabalhos recentes com cardiomiócitos e células nervosas derivados de células tronco embrionárias demonstraram que essas linhagens também são capazes de formar conexões funcionais in vivo em modelos animais (RIPPON \& BISHOP, 2004). Por sua vez, BHAGAVATI \& XU (2005) induziram a diferenciação de corpos embrióides murinos em músculo antes do transplante 
in vivo, observando o seu desenvolvimento em tecido muscular esquelético normal. No entanto, ainda é necessário que haja mais pesquisas antes que esta técnica seja avaliada como realmente eficaz no tratamento de doenças degenerativas em humanos.

Por outro lado, a indução da diferenciação das células tronco adultas em vários tecidos ainda vem sendo investigada com uma possível aplicação clínica (KRAMPERA et al., 2006). Dentre as células tronco adultas, as células hematopoiéticas são as que estão melhor caracterizadas. Elas, que são originadas na medula óssea, provêm uma contínua fonte de progenitores de leucócitos, plaquetas, monócitos, granulócitos e linfócitos. A plasticidade dessas células em adquirir características de outras linhagens celulares diferentes da hematopoiética a torna amplamente estudada, devido ao seu potencial de utilização terapêutico.

Entretanto, todos os estudos com células tronco hematopoiéticas têm mostrado que a freqüência de incorporação destas células no músculo esquelético é muito pequena, apresentando pouca melhora no fenótipo distrófico. Estudos em camundongos $m d x$ mostram que células derivadas da medula óssea migram para áreas de degeneração muscular, sofrem diferenciação e contribuem com a regeneração de fibras danificadas, numa taxa que varia de menos de $1 \%$ a mais de $10 \%$ (FERRARI et al., 1998; BITTNER et al., 1999; GUSSONI et al., 1999; FERRARI et al., 2001). O baixo impacto na regeneração celular pode indicar um número insuficiente de progenitores miogênicos presentes no transplante para produzir massa muscular sadia, ou que o músculo distrófico do camundongo não gerou sinalização eficiente para a sua transição para músculo, ou que eles não teriam sido transplantados de maneira correta.

Para tentar minimizar a baixa eficiência desses testes, experimentos envolvendo o uso de células tronco de medula óssea purificadas vêm sendo realizados. FRIEDENSTEIN 
et al. (1976) foram os primeiros pesquisadores a observar que a medula óssea continha células com formato de fibroblastos, denominadas células tronco mesenquimais (MSC), que eram capazes de diferenciarem-se em outros tipos celulares. Desde então, vários estudos têm avançado no entendimento do fenótipo, fisiologia, potencial de diferenciação e possíveis aplicações clínicas dessas células, que podem ser expandidas in vitro, pois aderem em placas de cultura, e proliferam, formando colônias celulares com o formato de fibroblastos (PEREIRA et al., 1995; PITTENGER et al., 1999). Fenotipicamente, as células tronco mesenquimais expressam um conjunto de marcadores de membrana que são específicos desta linhagem celular. Já se sabe que as MSC não expressam os marcadores hematopoiéticos CD34 e CD45, mas elas podem expressar, por exemplo, CD13, CD29 e CD44 (CHAMBERLAIN et al., 2007). Além disso, outra característica inerente dessas células é de que elas são mais comprometidas com tecido muscular em passagens iniciais (DI ROCCO et al., 2006).

Atualmente, já se sabe que células mesenquimais derivadas do estroma da medula óssea dão origem a outros tecidos não hematopoiéticos, como osso, cartilagem e tecido conectivo in vivo (PEREIRA et al., 1995; PROCKOP, 1997) e in vitro (PITTENGER et al., 1999; DEANS \& MOSELEY, 2000; MINGUELL et al., 2000) e que podem ser fonte relevante de células com potencial de formar músculos in vitro (WAKITANI et al., 1995).

Devido a sua grande capacidade de auto-renovação, a sua plasticidade, a sua habilidade de circular na corrente sanguínea e uma maior facilidade de isolamento e cultura, as células mesenquimais aparecem como uma ferramenta atraente no contexto da engenharia genética e da terapia celular, e já vem sendo utilizadas no tratamento de doenças hematopoiéticas e osteogenesis imperfecta (BAKSH et al., 2004). 
Além disso, essas células podem ser diretamente obtidas dos pacientes, eliminando, desta forma, complicações associadas com a rejeição imune. Por isso, como outra possível forma de tratamento de pacientes com DMD já se tem utilizado, com êxito, a injeção alogênica de células geneticamente modificadas a fim de reduzir a rejeição após o transplante. GONÇALES et al. (2006) também exploraram o potencial das células tronco mesenquimais geneticamente modificadas com seqüências codificadoras de distrofina e verificaram fusão celular das células injetadas com as presentes no organismo do doador.

Porém, um obstáculo encontrado no caso das terapias celular e gênica para doenças envolvendo células largamente distribuídas pelo corpo, como as células musculares, é o desafio de disseminar as células ou os genes transplantados para os tecidos ou órgãos afetados. Já é sabido que progenitores miogênicos expressando marcadores musculares estão presentes na medula óssea e migram para o seu nicho apropriado logo após a sua implantação, atraídos por estímulos de degeneração. Sugere-se que os tecidos injuriados expressem receptores específicos que facilitariam o tráfego, a adesão e a infiltração de MSC ao local lesionado. Se confirmado o que foi proposto no trabalho pioneiro de FERRARI et al. em 1998, as células mesenquimais seriam capazes de acessar a musculatura esquelética degeneradas, quando transplantada sistematicamente em camundongos $m d x$, e participar do reparo muscular. Caso isso ocorra também em humanos, a descoberta da existência de células que percorram uma grande quantidade de frações musculares quando transplantadas, pode abrir novos horizontes no desenvolvimento de terapias para a distrofia muscular.

No entanto, muitas questões fundamentais a respeito da biologia celular e molecular das células tronco devem ser desvendadas antes. Por exemplo: apesar do seu grande potencial, um dos principais obstáculos no uso das células mesenquimais é o seu número 
limitado de gerações em cultura, e, levando-se em conta que as aplicações clínicas requerem um número significante de células para obter sucesso, torna-se necessário o desenvolvimento de novas estratégias para prolongar a sua capacidade replicativa.

Existem diversos pontos que fazem das células tronco adultas menos atrativas que as embrionárias. As células tronco adultas, de uma forma geral, são raras, além de serem difíceis de identificar, isolar e purificar. Além disso, por serem células adultas, sofrem ação de toxinas e mutações genéticas acumuladas com o seu tempo de vida. Por outro lado, a utilização de células adultas, não apenas nos isentariam das questões ético-religiosas que cercam a utilização de células tronco embrionárias humanas, assim como contornaria os problemas de rejeição imunológica, uma vez que células tronco do próprio paciente poderiam servir de fonte de regeneração tecidual. Atualmente com a liberação do uso controlado das células tronco embrionárias humanas (hESCs) nas pesquisas de seu uso em terapias celulares, elas se tornaram também uma promissora fonte de células para terapia em doenças degenerativas, sem a formação de teratoma (BARBERI et al., 2007).

Portanto, desvendar as características e o potencial das células tronco consiste em promissora perspectiva para o desenvolvimento de novas terapias para doenças genéticas. Para isto, torna-se imprescindível determinar a linhagem de células tronco mais viável capaz de promover a reparação ou a substituição perfeita do tecido em estudo. 
2. OBJETIVOS 
Baseados em diversos trabalhos que demonstram a capacidade de células tronco murinas de participarem na regeneração de músculo esquelético, será testada a sua possível utilidade clínica em terapia de DMD no modelo murino $m d x$, através do (a):

1-) Extração, cultivo e caracterização de células tronco mesenquimais isolados de medula óssea de camundongos normais e eGFP;

2-) Cultivo de células tronco embrionárias extraídas de massa interna de blastocistos de camundongos normais;

3-) Investigação do potencial miogênico dessas células, quando co-cultivadas com mioblastos provenientes de camundongos $m d x$ : fusão e capacidade de passar a produzir a proteína distrofina exógena;

4-) Investigação do potencial miogênico dessas células, quando transplantadas em camundongos distróficos $m d x$ : estudo do músculo e identificação de fibras musculares expressando distrofina exógena. 
3. MATERIAL E MÉTODOS 


\subsection{Camundongos}

Foram utilizadas as linhagens de camundongos $m d x$ (camundongo distrófico), C57black6 (camundongo normal) e FVB eGFP transgênico expressando a proteína fluorescente verde GFP. A linhagem de camundongos $m d x$ está sendo mantida no biotério da Faculdade de Medicina Veterinária e Zootecnia da USP e os camundongos C57black6 foram obtidos do Instituto de Ciências Biomédicas da USP. Foi estabelecida no biotério do Centro de Estudos do Genoma Humano uma colônia desses camundongos a partir de 1 casal de camundongo de cada linhagem. A partir daí, foram realizados cruzamentos consecutivos para multiplicar a colônia com a finalidade de se utilizar as ninhadas em nossos experimentos. Os camundongos eGFP foram gentilmente cedidos pelo Dr. José Xavier Neto do Laboratório de Genética e Cardiologia Molecular do InCor-HC. Nosso laboratório recebeu a doação de 2 machos da espécie $F V B$, expressando constitutivamente a proteína fluorescente verde (GFP) e de 1 fêmea da mesma espécie selvagem. Inicialmente, foram cruzados 1 dos machos eGFP com a fêmea selvagem. O nosso próximo passo foi a caracterização de sua prole, como eGFP ou não, para a formação de novos casais, com o objetivo de termos bastante prole viável expressando a proteína. Para tal, conta-se com a ajuda de um óculos especial que tem uma lâmpada acoplada que emite luz UV, e que tem um filtro que permite a visualização da fluorescência transmitida pelo camundongo. Com isso, está se selecionando os camundongos para os experimentos, assim como se tentando formar casais de animais de fluorescência mais forte, uma vez que suas células são mais facilmente detectadas ao microscópio de fluorescência (BRAZELTON \& BLAU, 2005). 


\subsection{Cultura de mioblastos}

A cultura de mioblastos primários foi estabelecida a partir de fragmentos musculares de camundongos $m d x$, normais e eGFP, e cresceram seguindo o protocolo de cultura de mioblastos humanos, como descrito posteriormente. Para a obtenção das culturas, foram sacrificados camundongos das 3 linhagens em câmara de $\mathrm{CO}_{2}$, com a finalidade de se extrair tecido muscular. Esses tecidos foram, então, dissociados e implantados em garrafas de cultura estéreis contendo meio essencial de cultura Dulbecco modified Eagle medium (DMEM, GIBCO), com ácido N-2-hidroxietilpiperazina-N'-2etanosulfônico (HEPES), acrescido de $20 \%$ de Soro Fetal Bovino (SFB, GIBCO) e $1 \%$ de antibióticos penicilina e estreptomicina (GIBCO), e incubados em estufa mantida a $37^{\circ} \mathrm{C}$ com $5 \%$ de $\mathrm{CO}_{2}$ em ambiente úmido.

Após 4 a 7 dias, iniciou-se o processo de liberação das células satélites (mioblastos) presentes no fragmento muscular, e a sua proliferação foi monitorada, para que elas não entrassem em processo de diferenciação. A cada 2 dias, durante a incubação, as células foram analisadas (tamanho, aspecto morfológico, quantidade etc) e o meio de cultura foi trocado, até que atingiram o crescimento compatível a uma monocamada subconfluente (70\% da área cultivável recoberta por células).

Para se fazer um estoque destas linhagens celulares, as células multiplicaram-se até atingirem a confluência, quando, então, foram destacadas da placa por ação enzimática de Tripsina - solução de Tripsina 25\% e EDTA 1mM, em PBSA 1X (solução tampão fosfato salina sem cálcio e magnésio) - e utilizadas nos experimentos ou congeladas com a proteção de DMSO (dimetil sulfóxido), sendo conservadas em nitrogênio líquido. 
Com as células liberadas dos fragmentos de tecido de camundongos eGFP e normais, conseguimos congelar algumas ampolas, assim como realizar ensaios de diferenciação. Para se promover a diferenciação das células musculares, frascos com células atingindo a confluência foram cultivados com meio DMEM com 10\% de Soro de Cavalo (SC), até se fusionarem e ocorrer a formação de vários miotubos multinucleares.

Assim sendo, as culturas primárias de mioblastos de camundongos $m d x$ foram utilizadas nos estudos in vitro.

\subsection{Isolamento e cultura de células tronco mesenquimais de camundongos eGFP}

As células tronco mesenquimais (MSC) podem ser diretamente isoladas de aspirados de medula óssea por causa de sua habilidade de adesão à superfície da garrafa de cultura. Sendo assim, camundongos normais e eGFP foram sacrificados numa câmara de $\mathrm{CO}_{2}$ e sua medula óssea aspirada do fêmur com meio de cultura. Após lavagem pela centrifugação a 1000 RPM por 5 minutos, as células foram ressuspendidas em meio $\alpha$ MEM (SIGMA-ALDRICH) contendo $10 \%$ de SFB (GIBCO) e 1\% de antibióticos penicilina e estreptomicina (GIBCO). A cultura foi mantida a $37^{\circ} \mathrm{C}$ em incubadora de $\mathrm{CO}_{2}$ com 5\% de umidade por 48 horas. Após esse tempo, as células que não aderiram à garrafa (linhagem hematopoiética e debris) foram removidas através da aspiração do meio de cultura, restando aderidas as células tronco mesenquimais. Depois de trocas consecutivas do meio, a cultura foi se tornando enriquecida e homogênea, com a remoção da contaminação inicial provocada pelas células hematopoiéticas também presentes na medula óssea recém extraída. 
Quando as células atingiram a confluência, foram realizadas subseqüentes passagens com a finalidade de proliferação, estocagem, caracterização e utilização das mesmas nos experimentos de diferenciação in vitro e de injeção dos camundongos $m d x$ e de outras linhagens.

\subsection{Cultura de células tronco embrionárias de camundongos}

\subsubsection{FEEDER - substrato para o crescimento de células ES.}

Para se obter o FEEDER (fibroblastos embrionários de camundongos inativados mitoticamente), retirou-se, com ajuda de uma lupa, a cabeça e os órgãos de embriões de camundongos normais e implantaram-se fragmentos de pele em garrafas de cultura, nas mesmas condições descritas previamente. Os embriões de camundongos utilizados para tal tinham entre 13 e 14 dias de gestação e foram retirados do útero da mãe, sacrificada por deslocamento cervical. Tivemos a colaboração da Dra. Silvia Massarouni, responsável pelo Biotério do Centro de Ciências Biológicas da USP, que nos ajudou cedendo estes embriões.

Depois de proliferar bastante, essas culturas foram tripsinizadas e colocadas em frascos, que foram encaminhados ao Departamento de Imunologia, no Instituto de Ciências Biológicas da USP, onde os fibroblastos foram irradiados a 4000 rads. Depois disso, foram imediatamente cultivados em frascos de cultura gelatinizados com o objetivo de serem utilizados como FEEDER para o cultivo das células embrionárias. Logo depois de aderidas, descongelou-se uma alíquota de células tronco embrionárias e procedeu-se ao seu cultivo.

Como a cultura das células embrionárias requer bastante FEEDER, o rendimento de sua proliferação é baixo, além de haver muita morte celular no momento da irradiação, produziu-se, incessantemente, estas células para se conseguir realizar os experimentos com as células embrionárias. 


\subsubsection{Cultivo e ampliação do estoque de células embrionárias de camundongos}

As células embrionárias utilizadas originaram-se da linhagem de camundongos 129, e foram previamente estabelecidas e congeladas no laboratório da Dra. Lygia da Veiga Pereira, do Departamento de Genética e Biologia Evolutiva, do Instituto de Biociências da USP. Procedeu-se ao seu cultivo, realizando subseqüentes passagens com a finalidade de proliferação e estocagem das mesmas, conforme previamente descrito por ROHWEDEL et al. (1994), com algumas modificações. Nosso próximo passo foi de utilizá-las para posteriores experimentos de implantação em camundongos e co-cultura.

As células ES foram descongeladas sobre a camada de FEEDER e mantidas em meio DEMEM (GIBCO) suplementado com $10 \%$ de SFB (HYCLONE), 2mM de L-glutamina (SIGMA-ALDRICH), $1 \%$ de aminoácidos não essenciais (GIBCO), 0,15mM de monotioglicerol (SIGMA-ALDRICH) e 1\% de antibióticos penicilina e estreptomicina (GIBCO). Durante o estágio de proliferação, o meio foi suplementado com 1000 unidades/ml de LIF (CHEMICON). As colônias foram mantidas em incubadora a $37^{\circ} \mathrm{C}$ com $5 \% \mathrm{CO}_{2}$ e umidade até a confluência e o meio foi trocado todos os dias.

\subsubsection{Pré-diferenciação das células embrionárias de camundongos}

Para a diferenciação das células ES em diversos fenótipos, essas células foram cultivadas em agregados multicelulares denominados Corpos Embrióides (EB), na ausência de FEEDER e sem LIF no meio de cultura, através do método de hanging drop (FIGURA 4). 


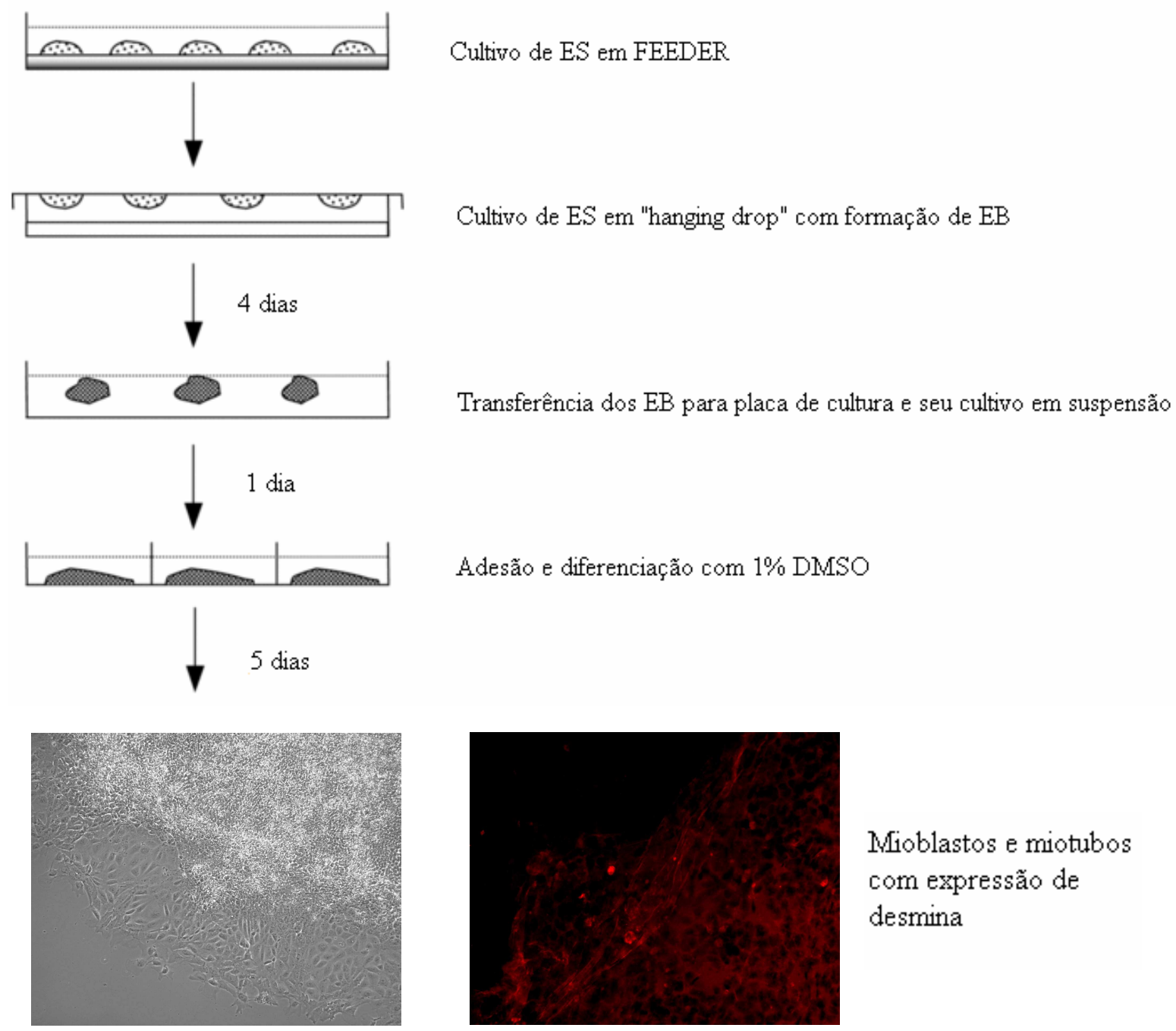

Figura 4: Diferenciação das ES pelo método de hanging drop.

Para a sua diferenciação, alíquotas de $20 \mu 1$ de meio de cultivo com 800 células foram plaqueadas em placas de Petri com PBS. Os agregados de células ES foram cultivados em hanging drops por 4 dias, quando a cultura foi transferida para garrafas, onde foi cultivada em suspensão por 1 dia e, então, novamente aderida, em um meio específico para diferenciação muscular, com 1\% de DMSO, sem LIF (WOBUS et al., 2002).

Nosso próximo passo depois de expandir a cultura das células embrionárias e da formação de corpos embrióides foi de sua implantação em camundongos $m d x$ e 
experimentos de co-cultura e diferenciação. Para isso, estas células foram submetidas ao tratamento com o corante vermelho Vybrant ${ }^{\circledR}$ Dil cell-labeling solution (INVITROGEN) para facilitar a sua visualização.

\subsection{Implantação de células tronco mesenquimais e embrionárias em camundongos}

MSC eGFP, células ES e EB, expandidos in vitro, foram injetados, intramuscular e sistemicamente, em camundongos de diversas linhagens, numa concentração de aproximadamente $10^{6}$ células por mililitro de PBSA. Em vários tempos após a infusão, diversos tecidos e músculos injetados (perna esquerda) e controles (perna direita) foram analisados, para verificar a eficiência do procedimento, através de(a):

a) Análise histológica e identificação direta por microscopia da presença das células marcadas com eGFP ou corante;

b) Identificação da presença das células injetadas por análise molecular por PCR de marcadores nucleares e microssatélites;

c) Pesquisa para o aparecimento de proteínas de linhagens musculares por imunohistoquímica e por Western blotting.

Todos os animais avaliados estão descritos na TABELA 1 e cada experimento está relatado na seqüência dos resultados. 


\begin{tabular}{|c|c|c|c|c|}
\hline $\begin{array}{c}\text { Nome do } \\
\text { camundongo }\end{array}$ & $\begin{array}{l}\text { Tipo de célula } \\
\text { injetada }\end{array}$ & $\begin{array}{c}\text { Local da } \\
\text { injeção }\end{array}$ & $\begin{array}{l}\text { Análise - Tempo } \\
\text { após a injeção } \\
\text { (sacrifício) }\end{array}$ & $\begin{array}{c}\text { Tecidos } \\
\text { analisados }\end{array}$ \\
\hline$M d x 1$ & MSC eGFP & Intramuscular & 3 semanas & Gastrocnêmio \\
\hline$M d x 2$ & MSC eGFP & Intramuscular & 1 dia & Gastrocnêmio \\
\hline$M d x 3$ & MSC eGFP & Intramuscular & 1 semana & Gastrocnêmio \\
\hline$M d x 13$ & $\begin{array}{l}\text { MSC eGFP de quarta } \\
\text { passagem }\end{array}$ & Intramuscular & 4 semanas & Gastrocnêmio \\
\hline$M d x 14$ & $\begin{array}{l}\text { MSC eGFP de quarta } \\
\text { passagem }\end{array}$ & Intramuscular & 4 semanas & Gastrocnêmio \\
\hline$M d x 15$ & $\begin{array}{l}\text { MSC eGFP de quarta } \\
\text { passagem }\end{array}$ & Intramuscular & 4 semanas & Gastrocnêmio \\
\hline$M d x 16$ & $\begin{array}{l}\text { MSC eGFP de quarta } \\
\text { passagem }\end{array}$ & Intramuscular & 4 semanas & Gastrocnêmio \\
\hline$M d x 17$ & $\begin{array}{l}\text { MSC eGFP de quarta } \\
\text { passagem }\end{array}$ & Intramuscular & 4 semanas & Gastrocnêmio \\
\hline$M d x 18$ & $\begin{array}{l}\text { MSC eGFP de quarta } \\
\text { passagem }\end{array}$ & Intramuscular & 4 semanas & Gastrocnêmio \\
\hline$M d x 19$ & $\begin{array}{l}\text { MSC eGFP de quarta } \\
\text { passagem }\end{array}$ & Intramuscular & 4 semanas & Gastrocnêmio \\
\hline$M d x 20$ & $\begin{array}{l}\text { MSC eGFP de quarta } \\
\text { passagem }\end{array}$ & Sistêmica & 4 semanas & $\begin{array}{c}\text { Gastrocnêmio } \\
\text { Diafragma } \\
\text { Fígado } \\
\text { Cauda }\end{array}$ \\
\hline$M d x 21$ & $\begin{array}{l}\text { MSC eGFP de quarta } \\
\text { passagem }\end{array}$ & Sistêmica & 4 semanas & $\begin{array}{c}\text { Gastrocnêmio } \\
\text { Diafragma } \\
\text { Fígado } \\
\text { Cauda }\end{array}$ \\
\hline$M d x 22$ & MSC eGFP & Intramuscular & 2 dias & Gastrocnêmio \\
\hline$M d x 23$ & MSC eGFP & Intramuscular & 3 dias & Gastrocnêmio \\
\hline$M d x 24$ & MSC eGFP & Intramuscular & 15 dias & Gastrocnêmio \\
\hline$M d x 25$ & MSC eGFP & Intramuscular & 1 mês & Gastrocnêmio \\
\hline$M d x 26$ & MSC eGFP & Sistêmica & 15 dias & $\begin{array}{c}\text { Gastrocnêmio } \\
\text { Diafragma } \\
\text { Fígado } \\
\text { Cauda }\end{array}$ \\
\hline$M d x 27$ & MSC eGFP & Sistêmica & 1 mês & $\begin{array}{c}\text { Gastrocnêmio } \\
\text { Diafragma } \\
\text { Fígado } \\
\text { Cauda }\end{array}$ \\
\hline$M d x 28$ & ES & Intramuscular & 2 dias & Gastrocnêmio \\
\hline$M d x 29$ & ES & Intramuscular & 1 semana & Gastrocnêmio \\
\hline$M d x 30$ & ES & Intramuscular & 15 dias & Gastrocnêmio \\
\hline$M d x 31$ & ES & Intramuscular & 1 mês & Gastrocnêmio \\
\hline
\end{tabular}




\begin{tabular}{|c|c|c|c|c|}
\hline $\begin{array}{c}\text { Nome do } \\
\text { camundongo }\end{array}$ & $\begin{array}{c}\text { Tipo de célula } \\
\text { injetada }\end{array}$ & $\begin{array}{l}\text { Local da } \\
\text { injeção }\end{array}$ & $\begin{array}{l}\text { Análise - Tempo } \\
\text { após a injeção } \\
\text { (sacrifício) }\end{array}$ & $\begin{array}{c}\text { Tecidos } \\
\text { analisados }\end{array}$ \\
\hline$M d x 32$ & $\mathrm{ES}$ & Sistêmica & 2 dias & $\begin{array}{c}\text { Gastrocnêmio } \\
\text { Diafragma } \\
\text { Fígado } \\
\text { Baço } \\
\text { Cauda } \\
\end{array}$ \\
\hline$M d x 33$ & ES & Sistêmica & 1 semana & $\begin{array}{c}\text { Gastrocnêmio } \\
\text { Diafragma } \\
\text { Fígado } \\
\text { Baço } \\
\text { Cauda }\end{array}$ \\
\hline$M d x 34$ & ES & Sistêmica & 15 dias & $\begin{array}{c}\text { Gastrocnêmio } \\
\text { Diafragma } \\
\text { Fígado } \\
\text { Baço } \\
\text { Cauda } \\
\end{array}$ \\
\hline$M d x 35$ & $\mathrm{ES}$ & Sistêmica & 1 mês & $\begin{array}{c}\text { Gastrocnêmio } \\
\text { Diafragma } \\
\text { Fígado } \\
\text { Baço } \\
\text { Cauda }\end{array}$ \\
\hline$M d x 36$ & $\mathrm{ES}$ & Intramuscular & 1 semana & Gastrocnêmio \\
\hline$M d x 37$ & $\mathrm{ES}$ & Intramuscular & 15 dias & Gastrocnêmio \\
\hline$M d x 38$ & $\mathrm{ES}$ & Intramuscular & 1 mês & Gastrocnêmio \\
\hline$M d x 39$ & ES & Sistêmica & 1 semana & $\begin{array}{c}\text { Gastrocnêmio } \\
\text { Diafragma } \\
\text { Fígado } \\
\text { Baço } \\
\text { Cauda }\end{array}$ \\
\hline
\end{tabular}




\begin{tabular}{|c|c|c|c|c|}
\hline $\begin{array}{c}\text { Nome do } \\
\text { camundongo }\end{array}$ & $\begin{array}{l}\text { Tipo de célula } \\
\text { injetada }\end{array}$ & $\begin{array}{l}\text { Local da } \\
\text { injeção }\end{array}$ & $\begin{array}{l}\text { Análise - Tempo } \\
\text { após a injeção } \\
\text { (sacrifício) }\end{array}$ & $\begin{array}{c}\text { Tecidos } \\
\text { analisados }\end{array}$ \\
\hline$M d x 40$ & $\mathrm{ES}$ & Sistêmica & 15 dias & $\begin{array}{c}\text { Gastrocnêmio } \\
\text { Diafragma } \\
\text { Fígado } \\
\text { Baço } \\
\text { Cauda } \\
\end{array}$ \\
\hline$M d x 41$ & EB & Intramuscular & 1 mês & Gastrocnêmio \\
\hline$M d x 42$ & EB & Intramuscular & 1 mês & Gastrocnêmio \\
\hline$M d x 43$ & EB & Intramuscular & 2 meses & Gastrocnêmio \\
\hline$M d x 44$ & EB & Intramuscular & 2 meses & Gastrocnêmio \\
\hline$M d x 45$ & $\mathrm{~EB}$ & Sistêmica & 1 mês & $\begin{array}{c}\text { Gastrocnêmio } \\
\text { Diafragma } \\
\text { Fígado } \\
\text { Baço } \\
\text { Cauda }\end{array}$ \\
\hline$M d x 46$ & $\mathrm{~EB}$ & Sistêmica & 2 meses & $\begin{array}{c}\text { Gastrocnêmio } \\
\text { Diafragma } \\
\text { Fígado } \\
\text { Baço } \\
\text { Cauda }\end{array}$ \\
\hline$F V B 1$ & MSC eGFP & Intramuscular & 2 dias & Gastrocnêmio \\
\hline$F V B 2$ & MSC eGFP & Intramuscular & 7 dias & Gastrocnêmio \\
\hline$F V B 3$ & MSC eGFP & Intramuscular & 1 mês & Gastrocnêmio \\
\hline C57black6 1 & MSC eGFP & Intramuscular & 2 dias & Gastrocnêmio \\
\hline C57black6 2 & MSC eGFP & Intramuscular & 7 dias & Gastrocnêmio \\
\hline C57black6 3 & MSC eGFP & Intramuscular & 1 mês & Gastrocnêmio \\
\hline
\end{tabular}

Tabela 1: Camundongos injetados local e sistemicamente com MSC eGFP, células ES e células EB nos experimento de implantação in vivo. 


\subsection{Co-cultura de células tronco mesenquimais e embrionárias com mioblastos de camundongos $m d x$ e experimentos de diferenciação in vitro}

Realizaram-se os experimentos de co-cultura das células misturando-se um número equivalente de mioblastos de camundongos $m d x$ com (a) células tronco mesenquimais expressando a proteína GFP ou (b) células tronco embrionárias.

Foi também testada a capacidade das MSC e das células ES de se diferenciarem em músculo espontaneamente por contato ou através de seu cultivo em meios de cultura diferentes. As células foram mantidas até a confluência e estimuladas a se diferenciarem em músculo. No final de cada experimento, as culturas foram submetidas ao processo de extração de RNA e de proteínas para a sua análise molecular e através da técnica de Western blotting.

\subsection{Congelamento e processamento das biópsias de diferentes tecidos}

Fragmentos musculares e de outros tecidos de camundongos injetados e controles, foram colhidos e processados imediatamente. Cada fragmento foi dividido, para análise de DNA e de proteínas no mesmo material. Em uma das metades foi extraído DNA. A segunda metade foi fixada em bloco de cortiça, mantendo-se a orientação das fibras musculares e congelada em nitrogênio líquido. O tecido congelado foi cortado em criostato com cortes de $5 \mu \mathrm{m}$ de espessura, de modo que as fibras se apresentassem em disposição transversal na lâmina, previamente coberta por polilisina. As lâminas foram mantidas em freezer $-70^{\circ} \mathrm{C}$ até o momento da sua utilização para os experimentos de coloração e de imunohistoquímica, quando foram deixadas em temperatura ambiente, por aproximadamente 1 h. Já para a análise por Western blotting, os fragmentos de mesmo 
tamanho foram diretamente congelados também em nitrogênio líquido, macerados e submetidos ao processo de extração de proteínas.

\subsection{Caracterização e detecção das células e de proteínas relacionadas com a diferenciação miogênica}

\subsubsection{Tentativa de visualização direta das células recém-injetadas}

Assim que os tecidos congelados foram cortados, as lâmina com os cortes histológicos foram analisadas em microscópio de epi-fluorescência, no comprimento de onda relativo ao filtro que capta a fluorescência verde da proteína GFP (FITC: 515-565nm) e o corante vermelho (Cy3: 575-640nm), com o objetivo de tentarmos localizar as células implantadas. Para isso, a lâmina foi montada com Vectashield.

\subsubsection{Coloração de Hematoxilina-Eosina}

A coloração com hematoxilina foi realizada por 10 minutos, seguida por lavagem em água corrente por 10 minutos. Já a coloração por eosina foi realizada por 3 minutos, com posterior lavagem, até sair todo o excesso de corante. As lâminas foram fixadas com ácido acético e montadas com Bálsamo do Canadá.

\subsubsection{Imunohistoquímica de células e de tecidos}

A técnica de imunohistoquímica para detecção de proteínas musculares foi realizada com marcação simples conforme descrito por VAINZOF et al. (1991), com pequenas alterações. As lâminas de cortes histológicos por congelação ou de células foram umidificadas com PBS $1 \mathrm{X}$ e incubadas por, pelo menos, 3 horas, com anticorpo primário na diluição pré-estabelecida no laboratório. Lavou-se 3 vezes com PBS 1X e incubou-se com o segundo anticorpo (soro anti-IgG conjugado com fluoróforo), por 1 hora em temperatura 
ambiente no escuro. Lavou-se mais 3 vezes e montou-se com Vectashield. A análise das lâminas foi realizada em microscópio de epi-fluorescência com filtros específicos para cada fluoróforo. Em todas as reações, foram utilizados cortes histológicos controles positivos de camundongos para validar o experimento.

Para a análise imunohistoquímica de MSC e de células ES, essas foram transferidas para aderir e crescer em lâminas (Flasketts Chambers, Nunc) e mantidas também sob as mesmas condições de cultivo das garrafas.

A identificação das proteínas foi feita através dos anticorpos primários, desenvolvidos em diferentes animais:

- ANTI-DISTROFINA AB-15277 (ABCAM): Anticorpo policlonal de região Nterminal da distrofina desenvolvido em coelho.

- ANTI-GFP AB-3080 (CHEMICON): Anticorpo policlonal anti-GFP produzido em coelho.

- ANTI-LAMINA A/C (CHEMICON): Anticorpo monoclonal anti-lamina A/C produzido em camundongo.

- ANTI-MIOSINA FETAL NCL-MHCd (NOVOCASTRA): Anticorpo monoclonal anti-miosina fetal produzido em camundongo.

- ANTI-DESMINA D-8281 (SIGMA ALDRICH): Anticorpo policlonal desenvolvido em coelho.

Já na caracterização de células mesenquimais de camundongos utilizou-se os seguintes anticorpos:

- CD 13 (BD Pharmingen): Anticorpo monoclonal produzido em rato.

- CD 29 (BD Pharmingen): Anticorpo monoclonal produzido em hamster. 
- CD 34 (ABCAM): Anticorpo monoclonal de produzido em rato.

- CD 44 (BD Pharmingen): Anticorpo monoclonal produzido em rato.

- CD 45 (BD Pharmingen): Anticorpo monoclonal produzido em rato.

- CD 90 (BD Pharmingen): Anticorpo monoclonal produzido em rato.

- CD 105 (BD Pharmingen): Anticorpo monoclonal produzido em rato.

Os anticorpos secundários utilizados foram:

- ANTI-COELHO: conjugado com Cy3 (vermelho).

- ANTI-RATO: conjugado com FITC (verde).

- ANTI-HAMSTER: conjugado com Cy3 (vermelho).

\subsubsection{Western blotting}

A metodologia descrita a seguir foi realizada no trabalho de ZUBRZYCKAGAARN et al. (1988): As células foram cultivadas em frascos próprios até a confluência, sendo então liberadas da garrafa e lavadas com PBS 1X. Por outro lado, os fragmentos de tecido foram pulverizados congelados em nitrogênio líquido. Depois de preparados e homogeneizados, ambos sofreram o processo de extração de proteínas, submetidos ao contato com tampão de solubilização fervente.

Para a determinação das bandas das proteínas em estudo, o experimento foi realizado, aplicando-se um volume de extrato de proteínas totais em gel de poliacrilamida. Após a eletroforese, o gel é eletro-transferido para uma membrana de nitrocelulose, sob corrente $350-450 \mathrm{~mA}$, durante 1 hora a temperatura de $4^{\circ} \mathrm{C}$. A membrana foi seca, lavada, e submetida à reação com anticorpos primários. Os anticorpos secundários utilizados foram ligados à fosfatase alcalina e a reação foi revelada com NBT e BCIP, evidenciando uma 
banda de coloração roxa. Uma amostra de peso molecular padrão foi incluída em cada blot para construção de curva de peso molecular.

Para esta análise, foram preparados extratos de proteínas dos músculos injetados e controles, de camundongos normais e $m d x$, assim como das culturas celulares primárias e de células diferenciadas.

A identificação das proteínas foi feita através dos anticorpos primários:

- ANTI-DISTROFINA VP-D508 (VECTOR): Anticorpo policlonal de região Nterminal desenvolvido em camundongo.

- ANTI-GFP AB-3080 (CHEMICON): Anticorpo policlonal anti-GFP produzido em coelho.

- ANTI-LAMINA A/C (CHEMICON): Anticorpo monoclonal anti-lamina A/C produzido em camundongo.

\subsubsection{Análise do DNA genômico}

\subsubsection{Gene eGFP e regiões polimórficas de camundongos}

$\mathrm{Na}$ tentativa de se rastrear as células implantadas através da seqüência de DNA foi realizada a extração de DNA das MSC eGFP, de ES, de músculo de controles normais e dos tecidos dos camundongos injetados e controles, através da técnica de precipitação com iso-propanol. Foi realizada, então uma reação de PCR (Reação em Cadeia da Polimerase) para o rastreamento de uma seqüência presente no gene GFP e para o rastreamento das células ES através da amplificação da mesma região do genoma dos camundongos, que geram produtos de tamanhos diferentes devido à presença de regiões polimórficas, referentes às linhagens de camundongos 129 (linhagem original das ES) e $m d x$ 
(http://www.informatics.jax.org/searches/probe.cgi?37495). Para tal, foram utilizados pares de primers específicos com as seqüências descritas na tabela abaixo (TABELA 2).

\begin{tabular}{|l|l|l|}
\hline GFP camundongo & (F) GCTATGTGGATACGCTGCTT & $400 \mathrm{pb}$ \\
\hline & (R) AGGAAGGTCCGCTGGATTGA & \\
\hline D19MIT1 & (F)AATCCTTGTTCACTCTATCAAGGC & $142 \mathrm{pb}(\mathrm{ES})$ \\
\hline & (R)CATGAAGAGTCCAGTAGAAACCTC & $121 \mathrm{pb}(\mathrm{mdx})$ \\
\hline
\end{tabular}

Tabela 2: Pares de primers com sequiências específicas presentes no gene GFP e nas regiões polimórficas dos camundongos.

O DNA foi quantificado em espectrofotômetro, utilizando-se para a PCR 60ng de DNA genômico, além de 2,0 pmol de cada oligonucleotídeo, 0,1 $\mathrm{mM}$ de dNTP (desoxinucleotídeos) e 1 unidade de Taq DNA polimerase, totalizando $25 \mu 1$.

Após a amplificação, os produtos de PCR foram visualizados em gel de eletroforese de poliacrilamida $8 \%$ - $10 \%$ que, após a migração das amostras, o gel foi permeado com brometo de etídeo $0,5 \mathrm{mg} / \mathrm{mL}$ e colocado em transiluminador de luz ultravioleta (UV), para ser fotografado pelo sistema de documentação de imagens Kodak Digital Science D1.

\subsubsection{Extração de RNA de músculo e de células}

Extraiu-se RNA total dos músculos dos camundongos injetados e controles e dos experimentos de cultura celular para o estudo da expressão de distrofina e fatores de transcrição envolvidos no processo de diferenciação e regeneração muscular. A extração de RNA do material foi realizada com o reagente Trizol® (Invitrogen), conforme as especificações do fabricante. O RNA foi diluído em água tratada com dietilpirocarbonato $0,01 \%$ (DEPEC) (livre de ribonucleases) e armazenado em freezer $-70^{\circ} \mathrm{C}$.

Para a síntese de DNA codificante total (cDNA), o RNA extraído foi quantificado em espectrofotômetro, utilizando-se $1 \mu \mathrm{g}$ de RNA total diluído em $5 \mu \mathrm{L}$ de água ultra pura 
(água classe 1), acrescentando-se $1.5 \mu \mathrm{g}$ de random primer e $0.5 \mu \mathrm{g}$ de oligo dT ao RNA e deixando-se 10 minutos a $65^{\circ} \mathrm{C}$ em termociclador. Após esta primeira incubação, adicionou-se os demais reagentes obtendo-se um tampão de reação 50mM de Tris- $\mathrm{HCl}$ pH 8,3 / 75mM de $\mathrm{KCl} / 3 \mathrm{mM}$ de $\mathrm{MgCl} 2$ (5x First Strand Buffer - Invitrogen), 10mM de DTT (Invitrogen), 50U/ $\mu \mathrm{L}$ de transcriptase reversa (SuperscriptTM II, Invitrogen), 0,25U de inibidor de ribonuclease (Invitrogen), $1 \mathrm{mM}$ de cada dNTP (Invitrogen) e água classe 1 tratada com DEPC, num volume total de $20 \mu 1$. A mistura foi incubada a $45^{\circ} \mathrm{C}$ por 1 hora em termociclador e o cDNA pronto foi estocado em freezer $-70^{\circ} \mathrm{C}$.

Foi, então realizada a amplificação semiquantitativa do cDNA através da reação em cadeia da polimerase (PCR). Para tal, foram utilizados pares de primers específicos para a PCR em cDNA dos genes, com as seqüências descritas na tabela abaixo (TABELA 3).

\begin{tabular}{|l|l|l|}
\hline Myf5 camundongo & (F) TGGTCCCGAAAGAACAGCAG & $97 \mathrm{pb}$ \\
\hline & (R) AGCAATCCAAGCTGGACACG & \\
\hline MyoD camundongo & (F) CGGCAGAATGGCTACGACAC & $116 \mathrm{pb}$ \\
\hline & (R) GAGATGCGCTCCACTATGCTG & \\
\hline Distrofina camundongo & (F) TCGCGACTTCGCCAAGGTACTAAA & $97 \mathrm{pb}$ \\
\hline & (R) TAACACAGTCTGCACTGGCAGGTA & \\
\hline Miostatina camundongo & (F) AACCTTCCCAGGACCAGGAG & $104 \mathrm{pb}$ \\
\hline & (R) CATCGCAGTCAAGCCCAAAG & \\
\hline
\end{tabular}

Tabela 3: Seqüências de oligonucleotídeos presente nos genes $M y f 5, M y o D$, Miostatina e Distrofina.

Após a amplificação, os produtos de PCR também foram visualizados em gel de eletroforese de poliacrilamida $8 \%$ - $10 \%$ e fotografados pelo sistema de documentação de imagens Kodak Digital Science D1. 


\subsection{Experimentos com células tronco mesenquimais}

\subsubsection{Estabelecimento da metodologia de isolamento e cultura de células tronco mesenquimais de camundongos}

A cultura de medula óssea total de camundongos normais C57black6 foi iniciada com a concentração ideal de aproximadamente $2 \times 10^{6}$ células/ml. Depois de trocas consecutivas do meio, a cultura foi se tornando homogênea e enriquecida em células MSC, com a remoção de outras células mononucleares não aderentes e não mesenquimais (FIGURA 5).
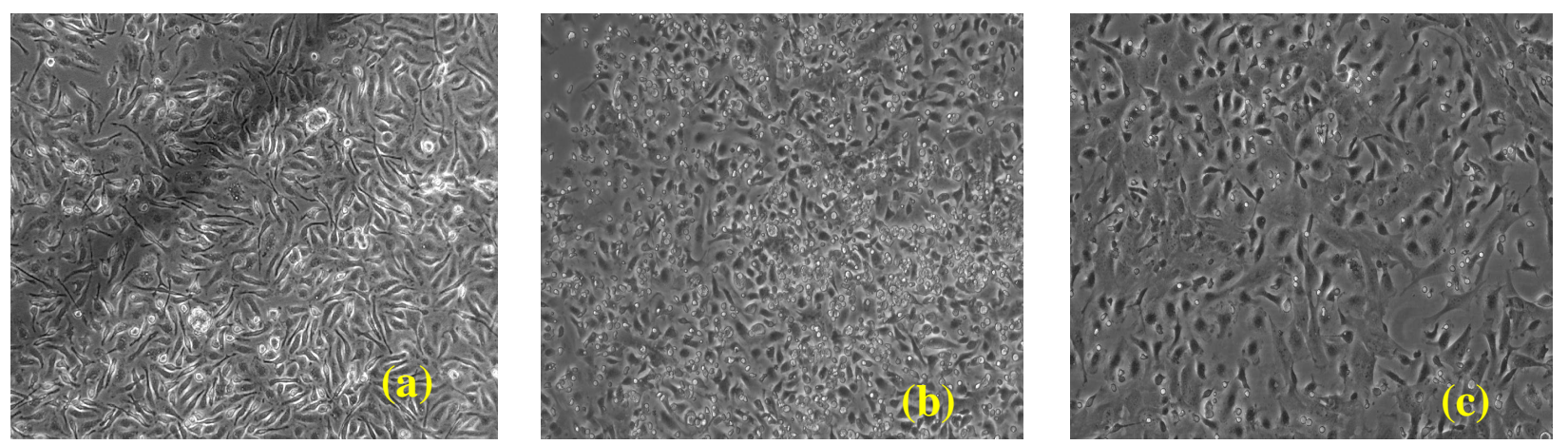

Figura 5: Isolamento e cultura de células mesenquimais de camundongo C57black6 (a) com 4 dias, (b) com 7 dias e (c) com 10 dias após sua adesão à superfície do frasco de cultura, mostrando o enriquecimento de células mesenquimais com o passar do tempo (Aumento $\mathrm{X}$ 100).

Depois de padronizada a técnica de cultivo de células MSC de camundongos normais, foi extraída medula óssea de camundongos eGFP, a fim de se cultivar células mesenquimais murinas já marcadas e de melhor visualização em cultura (FIGURA 6). 

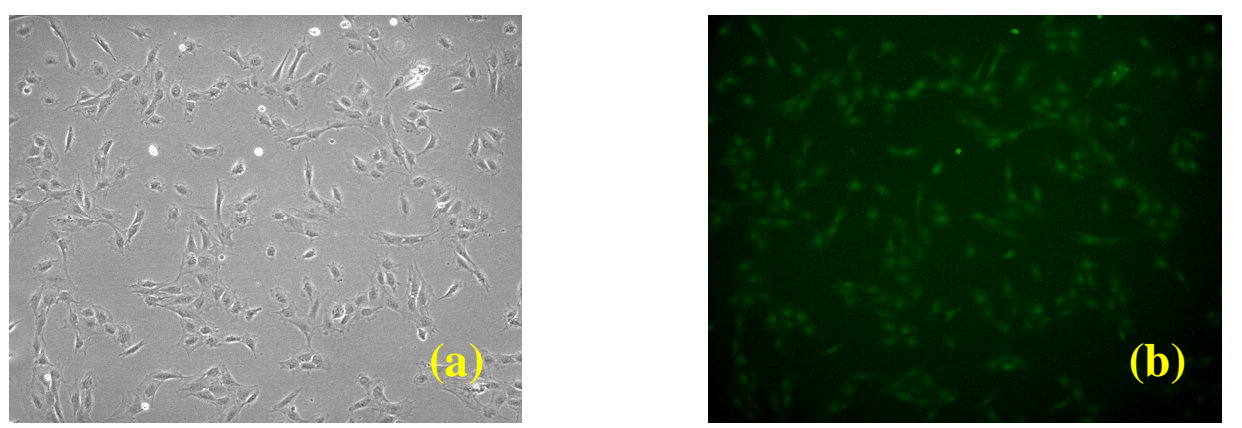

Figura 6: Cultura de células mesenquimais de camundongos eGFP. (a) visualização das células mesenquimais à luz visível e (b) no filtro para a fluorescência verde (Aumento X 100).

\subsubsection{Caracterização das células MSC}

Para comprovar as suas características de células mesenquimais, a cultura de células MSC foi caracterizada utilizando-se reações imunohistoquímicas, para determinar a presença ou não de marcadores já determinados como específicos para estas células (FIGURA 7). 


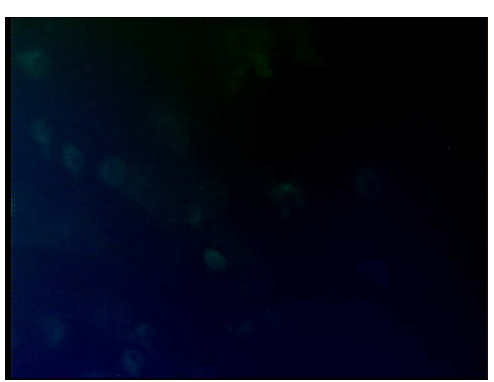

CD34

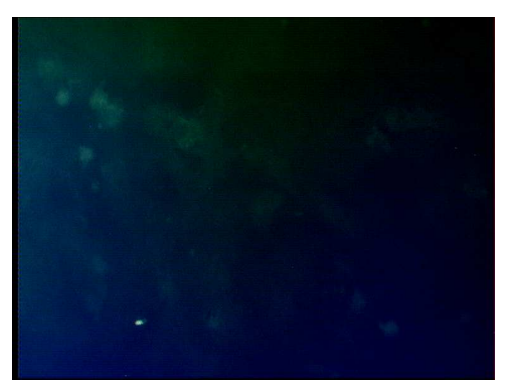

CD45

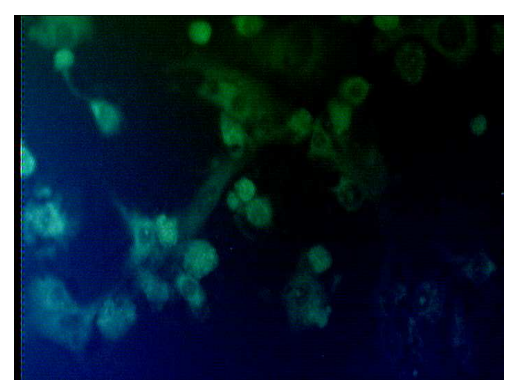

CD44

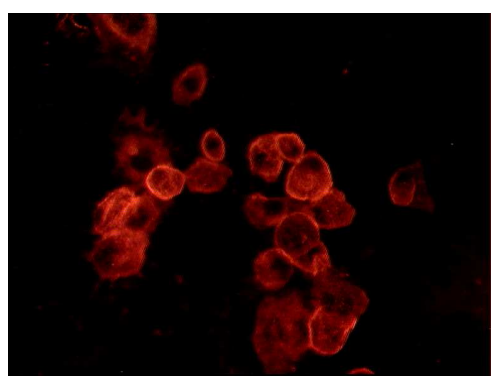

CD29

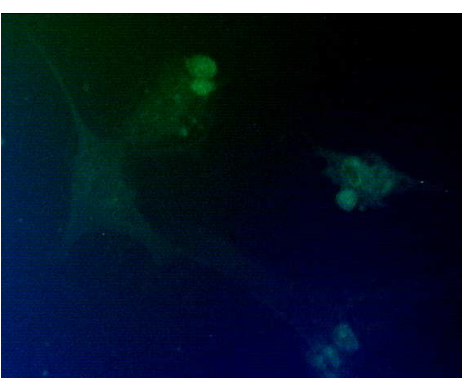

CD13

Figura 7: Reação de imunofluorescência de lâminas com células MSC com os diferentes anticorpos de membrana, mostrando marcação negativa para CD34 e CD45 e marcação positiva para CD13, CD29 e CD44 (Aumento X 200).

Conforme observado na FIGURA 6, as células apresentaram marcação negativa para CD34 e CD45 e marcação positiva para CD13, CD29 e CD44, comprovando suas características de células mesenquimais.

\subsubsection{Experimentos in vitro com células tronco mesenquimais}

\subsubsection{Experimentos de diferenciação espontânea das células MSC em mioblastos}

Tendo-se certeza a respeito da sua característica de célula tronco, testou-se primeiramente a capacidades das células mesenquimais de se diferenciarem espontaneamente em músculo in vitro. Com esta finalidade, células MSC foram cultivadas até que atingissem a 
confluência em meios de cultura suplementados com $20 \%$ de Soro Fetal Bovino até a visualização de células multinucleadas fundidas após 15 dias (FIGURA 8).
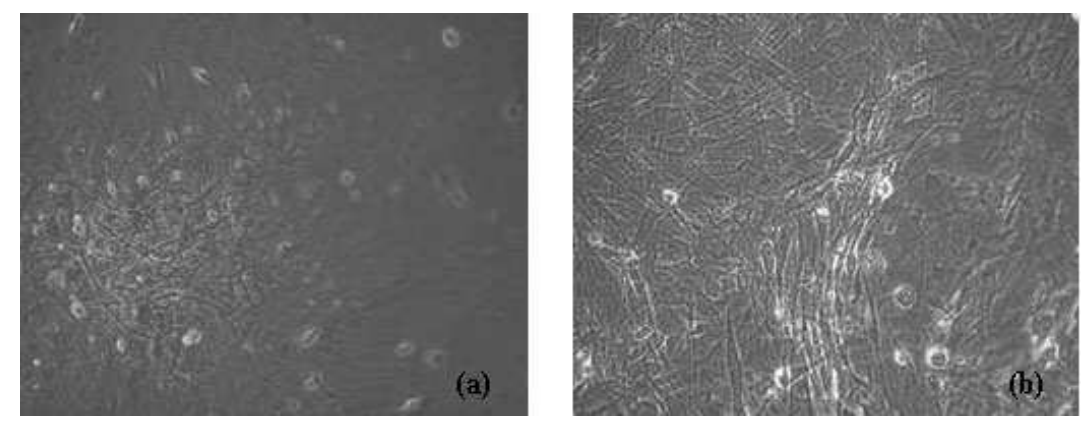

Figura 8: Cultura de células mesenquimais de camundongo eGFP em meio de cultura suplementado com 20\% de Soro Fetal Bovino, em que se verificou a ocorrência de fusão celular espontânea ((a) Aumento X 100 e (b) Aumento X 200).

\subsubsection{Experimentos de diferenciação induzida das células MSC em mioblastos}

Tentando reproduzir resultados descritos na literatura, foram realizados dois ensaios de diferenciação induzida com as células MSC, suplementando o seu meio de cultura com Hidrocortisona (SIGMA-ALDRISH) e Interleucina-6 (IL-6) (SIGMA-ALDRICH) (FIGURA 9). 


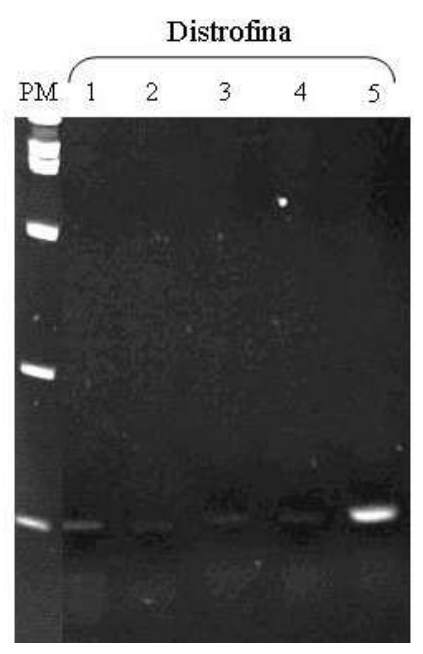

Figura 9: Reação de RT-PCR com primers específicos para cDNA de distrofina em (1) mioblastos C2C12, (2) células MSC em processo de diferenciação espontânea, (3) diferenciação induzida com hidrocortisona, (4) de diferenciação induzida com IL-6, (5) Músculo de camundongo C57black6.

Em todos os testes, as células MSC passaram a expressar distrofina, genes específicos de fibras musculares diferenciadas, sem a necessidade de outro tipo celular interferindo na cultura, o que mostra o grande potencial miogênico deste tipo celular (FIGURA 9).

\subsubsection{Experimentos de co-cultura de células MSC com mioblastos de camundongos mdx}

Cultivou-se um número equivalente de mioblastos obtidos de camundongos $m d x$ com células tronco mesenquimais expressando a proteína GFP e verificamos que ocorria fusão celular (FIGURA 10). 


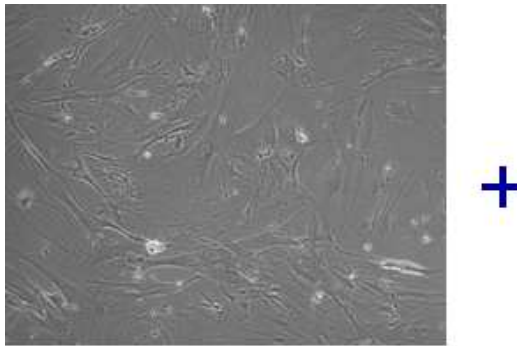

$\operatorname{MDX}$

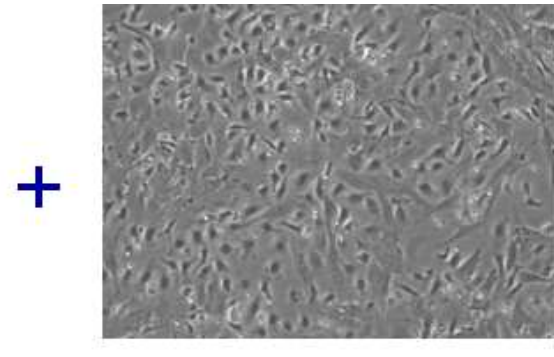

MSC

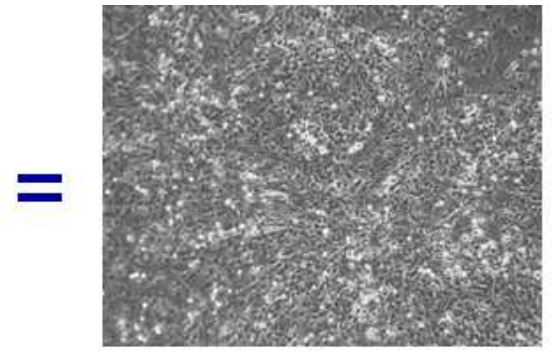

MSC + MDX

Figura 10: Co-cultura de mioblastos de camundongo $m d x$ com células mesenquimais de camundongo eGFP, com ocorrência de fusão celular (Aumento X 100).

Entretanto, não se pode provar que esta fusão ocorreu entre os 2 tipos celulares presentes, uma vez que a sua morfologia é bem parecida, além de não se ter conseguido visualizar a fluorescência verde das células eGFP ao microscópio de fluorescência após a fusão.

\subsubsection{Análise por Western Blotting da proteína distrofina nos experimentos de cultura com células MSC}

Reagiu-se os extratos de proteínas dos experimentos in vitro com as células MSC com anticorpo anti-distrofina na tentativa identificarmos a expressão desta proteína (FIGURA 11). 


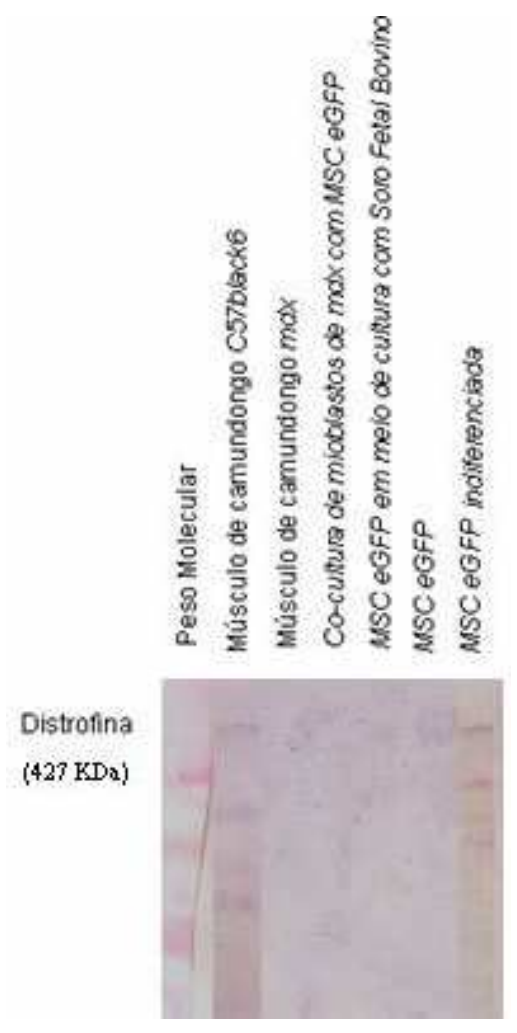

Figura 11: Western Blotting para a proteína distrofina das células do experimento de cultura.

Entretanto, o extrato de células mesenquimais em diferenciação espontânea apresentou uma marcação discreta para a distrofina, o que pode confirmar que as células MSC podem, em alguns momentos e sob o estímulo de proliferação, se diferenciar espontaneamente em músculo, sem necessitar do estímulo de mioblastos distróficos. 
4.1.4 Experimentos in vivo: Implantação de células MSC em camundongos

4.1.3.1 Experimento 1: Injeção intramuscular de células MSC eGFP-Análise após 4 semanas

Como um experimento piloto, células MSC eGFP, foram injetadas no músculo gastrocnêmio de 1 camundongo $m d x$ (TABELA 4), que foi sacrificado e seu músculo analisado após 4 semanas.

\begin{tabular}{|c|c|c|c|}
\hline $\begin{array}{c}\text { Nome do } \\
\text { camundongo }\end{array}$ & $\begin{array}{c}\text { Tipo de célula } \\
\text { injetada }\end{array}$ & $\begin{array}{c}\text { Tempo após a } \\
\text { injeção (sacrifício) }\end{array}$ & $\begin{array}{c}\text { Músculos } \\
\text { analisados }\end{array}$ \\
\hline$M d x 1$ & MSC eGFP & 4 semanas & Gastrocnêmio \\
\hline
\end{tabular}

Tabela 4: Camundongo injetado intramuscularmente com células MSC eGFP no experimento 1.

- Análise morfológica do músculo injetado e controle

Observou-se que a arquitetura das fibras musculares do músculo injetado se manteve compatível com aquela do músculo de camundongo $m d x$ controle (não injetado), que se apresentava com muitos focos de degeneração e de regeneração (FIGURA 12).
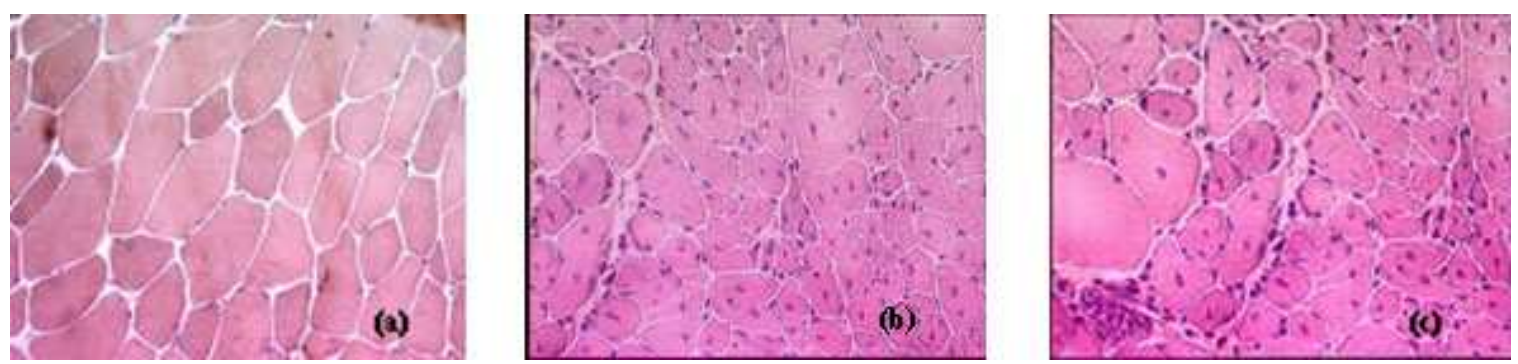

Figura 12: Coloração de hematoxilina-eosina em cortes histológicos do músculo gastrocnêmio de (a) camundongo normal, (b) camundongo $m d x$ controle e (c) camundongo $m d x$ injetado com células MSC (Aumento X 200). 
- Análise imunohistoquímica da proteína distrofina em músculo injetado e controle

Reagiu-se cortes histológicos de músculo controle e injetado com o anticorpo antidistrofina. Foi observado um padrão de fundo, com marcação intersticial entre as fibras musculares, tanto em cortes dos músculos do camundongo $m d x$ controle negativo, bem como nos músculos injetados (FIGURA 13). No entanto, não verificamos nenhum evento confiável que chamasse atenção para o aparecimento da proteína distrofina na membrana das fibras musculares, em padrão semelhante ao observado no músculo do camundongo controle normal.
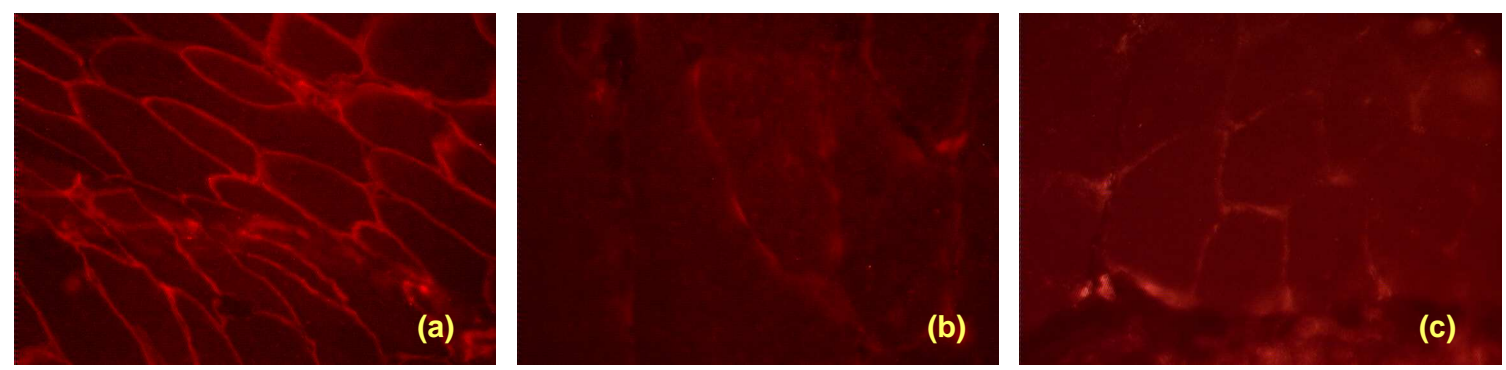

Figura 13: Reação de imunofluorescência com o anticorpo anti-distrofina em cortes histológicos do músculo gastrocnêmio de (a) controle positivo - camundongo C57black6, (b) camundongo $m d x$ não injetado, (c) camundongo $m d x$ injetado (Aumento X 200).

Além disso, não foi possível a identificação de células MSC eGFP injetadas no músculo desse camundongo, pois o músculo estriado e o tecido conjuntivo associado apresentaram forte autofluorescência (FIGURA 14). 


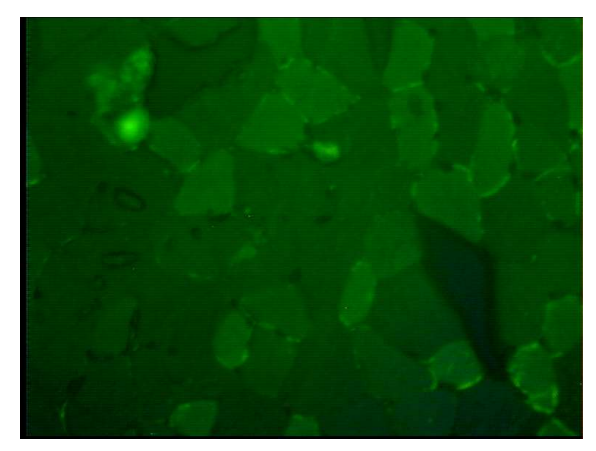

Figura 14: Observação direta do corte histológico de tecido muscular do camundongo $m d x$ injetado com células marcadas com GFP, mostrando forte autofluorescência observada no tecido (Aumento X 200).

- Análise por Western Blotting da proteína distrofina no músculo injetado e controle

Para se tentar identificar a presença da proteína distrofina difusa nas fibras musculares,fez-se um estudo por Western bloting dos extratos dos músculos do camundongo do experimento 1, e reagiu-se com anticorpo anti-distrofina (FIGURA 15). 


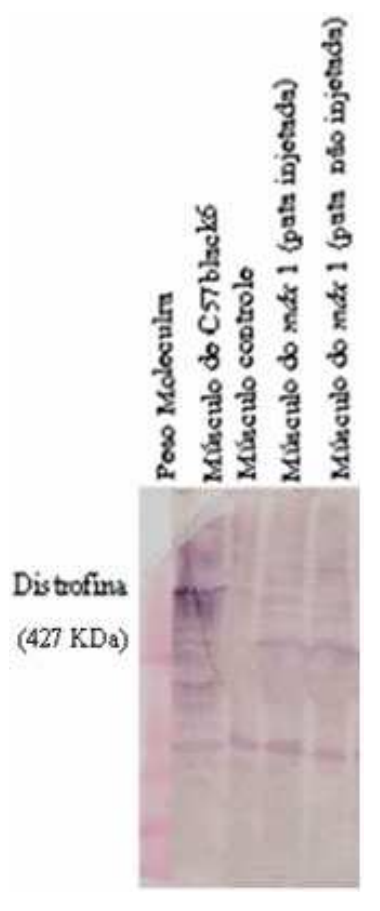

Figura 15: Western Blotting para a tentativa de detecção da proteína distrofina, em músculos gastrocnêmio injetado do camundongo do experimento 1 .

Entretanto, não foi possível identificar quantidade de distrofina significativa no músculo deste camundongo injetado, quando comparado com a marcação apresentada no músculo controle.

\subsubsection{Experimento 2 - Injeção intramuscular de células MSC eGFP - Análise após 1 dia e 1 semana}

Para se verificar como as células injetadas se distribuiriam e seria visualizadas no músculo injetado, realizou-se um experimento de curta duração. Células MSC eGFP foram injetadas no músculo gastrocnêmio de 2 camundongos $m d x$ (TABELA 5), que foram sacrificados e seus músculos analisados após 1 dia e 1 semana. 


\begin{tabular}{|c|c|c|c|}
\hline $\begin{array}{c}\text { Nome do } \\
\text { camundongo }\end{array}$ & $\begin{array}{c}\text { Tipo de célula } \\
\text { injetada }\end{array}$ & $\begin{array}{c}\text { Tempo após a } \\
\text { injeção (sacrifício) }\end{array}$ & $\begin{array}{c}\text { Músculos } \\
\text { analisados }\end{array}$ \\
\hline$M d x 2$ & MSC eGFP & 1 dia & Gastrocnêmio \\
\hline$M d x 3$ & MSC eGFP & 1 semana & Gastrocnêmio \\
\hline
\end{tabular}

Tabela 5: Camundongos injetados intramuscularmente com células MSC eGFP no experimento 2.

- Avaliação dos cortes histológicos dos músculos injetados e controles

Os cortes histológicos dos 2 camundongos foram analisados em microscópio de epifluorescência com filtro que capta a fluorescência verde da proteína eGFP (FIGURA 16), com a observação de alguns pontos que poderiam ser as células eGFP injetadas. Entretanto, não conseguimos ter certeza da detecção das células MSC nos músculos injetados.
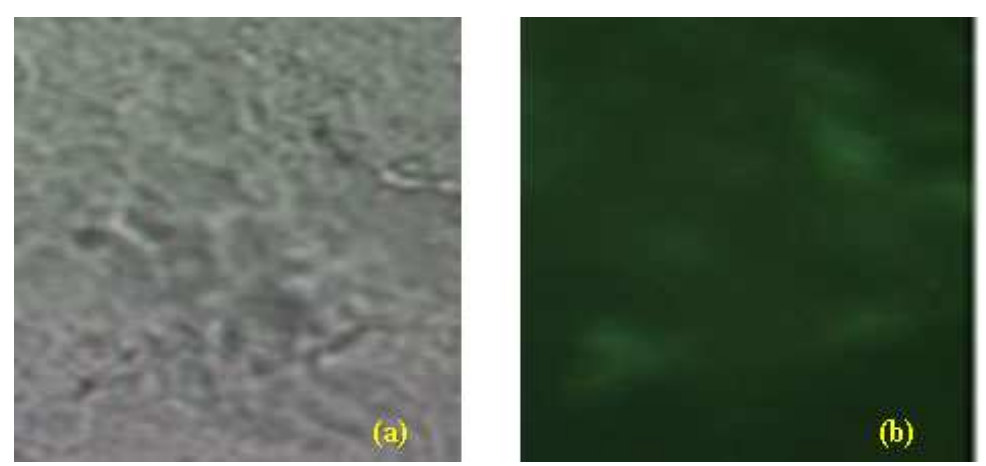

Figura 16: Visualização de cortes histológicos do músculo dos camundongos $m d x$ injetados no experimento 2. (a) visualização do corte do tecido muscular à luz visível e (b) visualização do mesmo campo de possíveis células eGFP (Aumento X 400). 
- Análise imunohistoquímica da proteína GFP em músculos injetados e controles

Reagiu-se cortes histológicos de músculos dos camundongos $m d x$ injetados do experimento 2 com o anticorpo anti-GFP. Como controles positivos da reação foram utilizados corte histológicos de músculo de camundongos FVB eGFP (FIGURA 17).
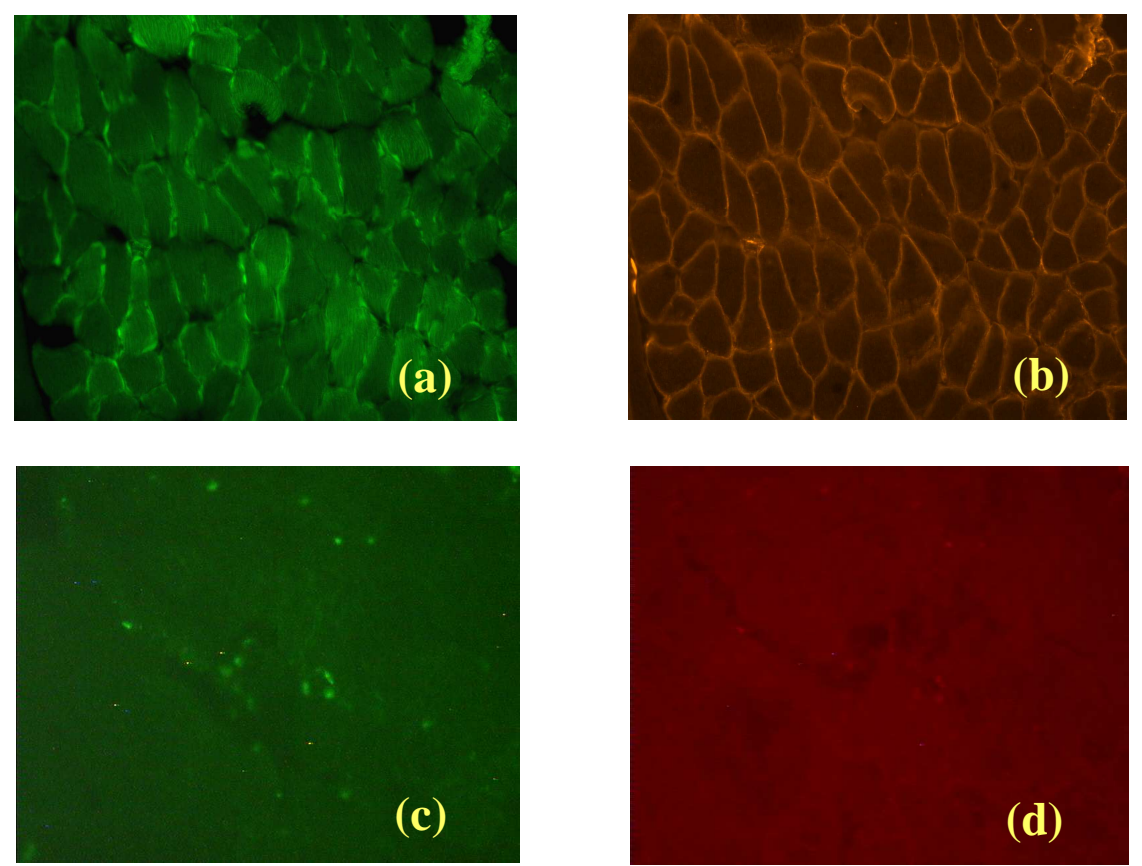

Figura 17: Reação de imunofluorescência com o anticorpo anti-GFP em cortes histológicos de músculos injetados dos camundongos do experimento 2. (a) camundongo $F V B$ eGFP em filtro de fluorescência verde, (b) reação do camundongo $F V B$ eGFP com o anticorpo, (c) camundongo $m d x$ injetado em filtro de fluorescência verde, (d) camundongo $m d x$ injetado reagido com a anticorpo anti-GFP (Aumento X 200).

As fibras musculares de $F V B$ eGFP mostraram reação positiva na observação direta com filtro FITC (FIGURA 17a) e reação positiva com o uso do anticorpo anti-GFP (FIGURA 17b). Os cortes histológicos dos camundongos injetados apresentaram uma pequena marcação no filtro de fluorescência verde (FIGURA 17c), mas esta reação não correspondeu com a marcação com o anticorpo específico (FIGURA 17d), não sendo possível identificar através desta 
metodologia as células injetadas pela da presença de proteína GFP no músculo dos camundongos.

- Análise por Western Blotting da proteína GFP nos músculos injetados e controles

Fez-se uma tentativa de reação do anticorpo anti-GFP, por Western Blotting, nos músculos dos camundongos do experimento 2 (FIGURA 18).

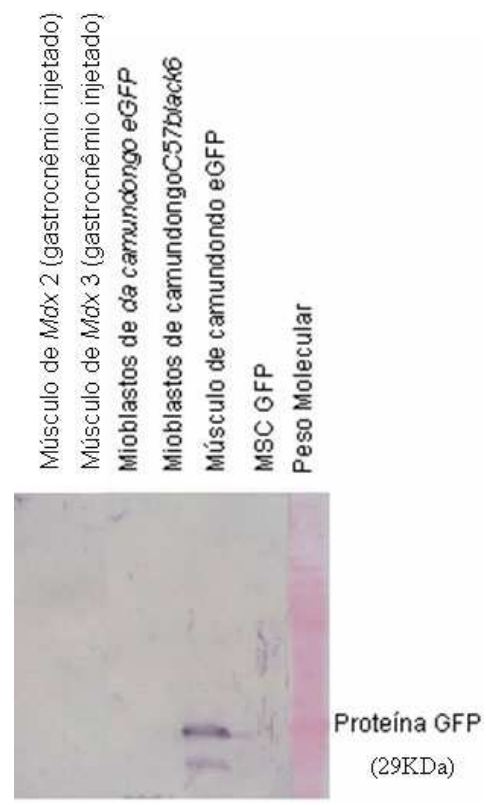

Figura 18: Western Blotting para rastreamento da proteína GFP nos músculos dos camundongos injetados no experimento 2 .

Só conseguiu-se visualizar a proteína GFP no músculo do camundongo $F V B$ eGFP, controle positivo. Por outro lado, também não se observou banda no extrato de proteínas de células dos camundongos GFP, sugerindo que pequenas quantidades de proteínas são mais difíceis de se identificar através desta metodologia. Portanto, com este anticorpo, também não foi possível identificar as células mesenquimais nos músculos dos camundongos injetados. 
4.1.3.3 Experimento 3 - Injeção intramuscular de células MSC eGFP de quarta passagem Análise após 4 semanas

Realizou-se um experimento com a implantação de células MSC eGFP de quarta passagem no músculo gastrocnêmio de 7 camundongos $m d x$, uma vez que elas se mostravam mais promissoras (TABELA 6). Esses animais foram sacrificado e seus músculos analisados após 4 semanas.

\begin{tabular}{|c|c|c|c|}
\hline $\begin{array}{c}\text { Nome do } \\
\text { camundongo }\end{array}$ & $\begin{array}{c}\text { Tipo de célula } \\
\text { injetada }\end{array}$ & $\begin{array}{c}\text { Tempo após a } \\
\text { injeção (sacrifício) }\end{array}$ & $\begin{array}{c}\text { Músculos } \\
\text { analisados }\end{array}$ \\
\hline$M d x 13$ & $\begin{array}{c}\text { MSC eGFP de } \\
\text { quarta passagem }\end{array}$ & 4 semanas & Gastrocnêmio \\
\hline$M d x 14$ & $\begin{array}{c}\text { MSC eGFP de } \\
\text { quarta passagem }\end{array}$ & 4 semanas & Gastrocnêmio \\
\hline$M d x 15$ & $\begin{array}{c}\text { MSC eGFP de } \\
\text { quarta passagem }\end{array}$ & 4 semanas & Gastrocnêmio \\
\hline$M d x 16$ & $\begin{array}{c}\text { MSC eGFP de } \\
\text { quarta passagem }\end{array}$ & 4 semanas & Gastrocnêmio \\
\hline$M d x 17$ & $\begin{array}{c}\text { MSC eGFP de } \\
\text { quarta passagem }\end{array}$ & 4 semanas & Gastrocnêmio \\
\hline$M d x 18$ & MSC eGFP de & 4 semanas & Gastrocnêmio \\
& quarta passagem & & 4 semanas \\
\hline$M d x 19$ & MSC eGFP de & & quarta passagem \\
& & & \\
\hline
\end{tabular}

Tabela 6: Camundongos injetados intramuscularmente com células MSC eGFP de quarta passagem no experimento 3 . 
- Análise imunohistoquímica para a proteína distrofina dos músculos injetados e controles

Reagiu-se cortes histológicos de músculos controles e injetados dos camundongos do experimento 3 com o anticorpo anti-distrofina. Entretanto, mais uma vez, todas as reações dos camundongos $m d x$ continuaram apresentando um padrão de marcação similar, com alguns focos de feixes musculares ligeiramente marcados, que podem ser confundido com autofluorescência ou fibras revertentes, presentes no músculo distrofico (FIGURA 19).
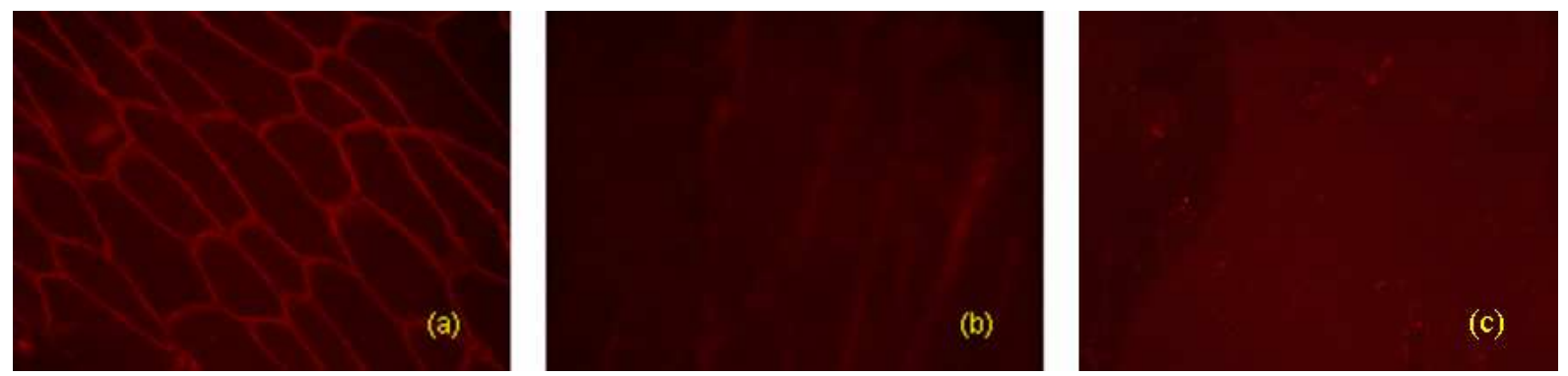

Figura 19: Reação de imunofluorescência de cortes histológicos de músculos dos camundongos injetados no experimento 3 com o anticorpo anti-distrofina. (a) controle positivo de camundongo, (b) camundongo $m d x$ não injetado, (c) camundongo $m d x$ injetado (Aumento $\mathrm{X}$ 200).

- Análise por Western Blotting da proteína distrofina nos músculos injetados e controles

Reagiu-se os extratos de proteínas dos músculos injetados e controles dos camundongos do experimento 3 com anticorpo anti-distrofina na tentativa identificarmos a presença desta proteína (FIGURA 20). 


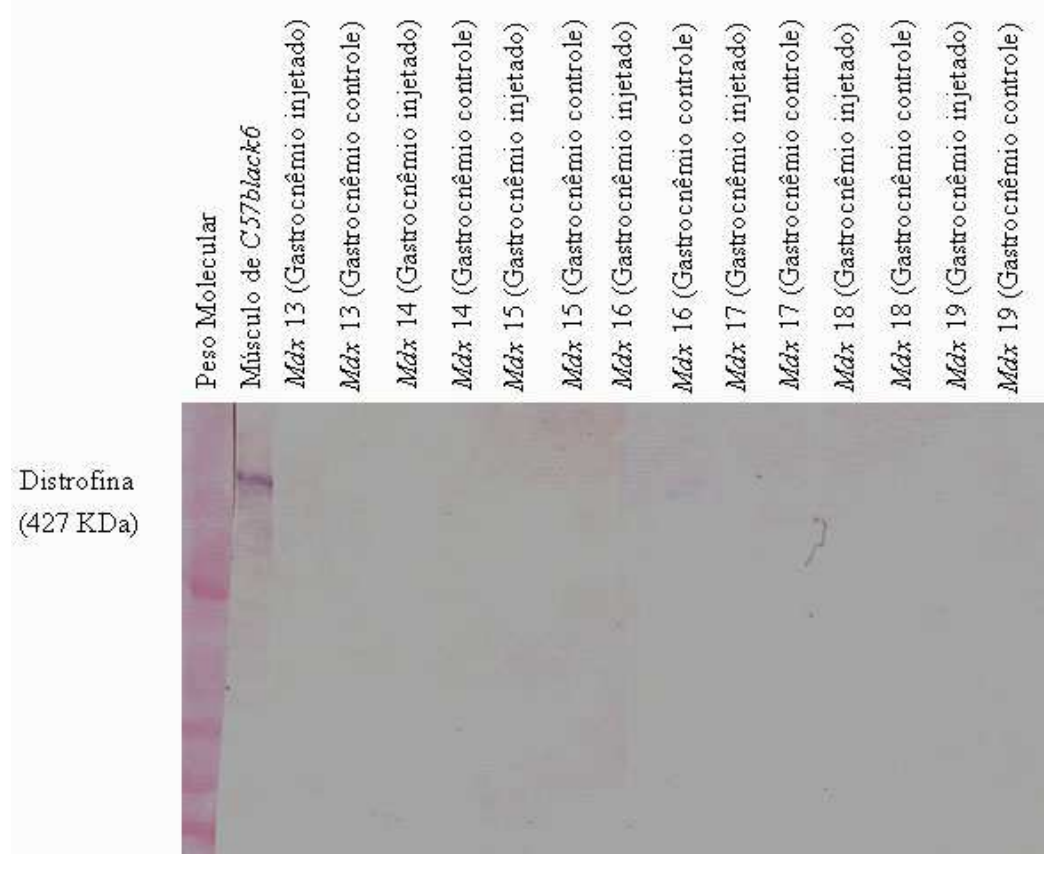

Figura 20: Western Blotting para a proteína distrofina nos extratos dos músculos dos camundongos injetados no experimento 3 .

Entretanto, o resultado desse experimento se manteve igual ao anterior, com a visualização da distrofina somente nos músculos controles positivos.

\subsubsection{Experimento 4 - Injeção sistêmica de células MSC eGFP - Análise após 4 semanas}

Em paralelo aos experimentos de injeções intramusculares de células MSC em camundongos $m d x$, também procedeu-se experimentos de implantação sistêmica dessas células (MSC eGFP de quarta passagem) (TABELA 7) e os animais injetados foram sacrificados e tiveram seus tecidos analisados após 4 semanas. 


\begin{tabular}{|c|c|c|c|}
\hline $\begin{array}{c}\text { Nome do } \\
\text { camundongo }\end{array}$ & $\begin{array}{c}\text { Tipo de célula } \\
\text { injetada }\end{array}$ & $\begin{array}{c}\text { Tempo após a } \\
\text { injeção (sacrifício) }\end{array}$ & Tecidos analisados \\
\hline$M d \times 20$ & MSC eGFP de & 4 semanas & Gastrocnêmio \\
& quarta passagem & & Diafragma \\
& & & Fígado \\
& & & Cauda \\
\hline$M d \times 21$ & MSC eGFP de & 4 semanas & Gastrocnêmio \\
& quarta passagem & & Diafragma \\
& & & Fígado \\
& & & Cauda \\
\hline
\end{tabular}

Tabela 7: Camundongos injetados sistemicamente com células MSC eGFP de quarta passagem no experimento 4.

- Reação de imunoflorescência e análise através de Western Blotting para a proteína distrofina dos músculos injetados e controles

Neste experimento, a análise da presença da proteína distrofina por imunofluorescência e Western blotting mostraram resultados semelhantes aos observados nos experimentos anteriores (FIGURA 21). 


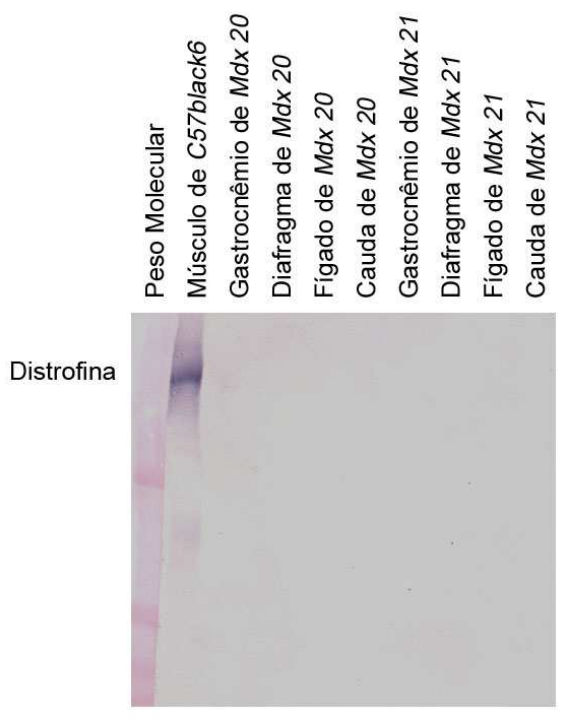

Figura 21: Western Blotting para a proteína distrofina nos extratos dos músculos dos camundongos injetados no experimento 4.

- Rastreamento do gene eGFP nos músculos injetados e controles

A partir deste experimento, passou-se a realizar reações de PCR com primers específicos para o gene eGFP (FIGURA 22). 


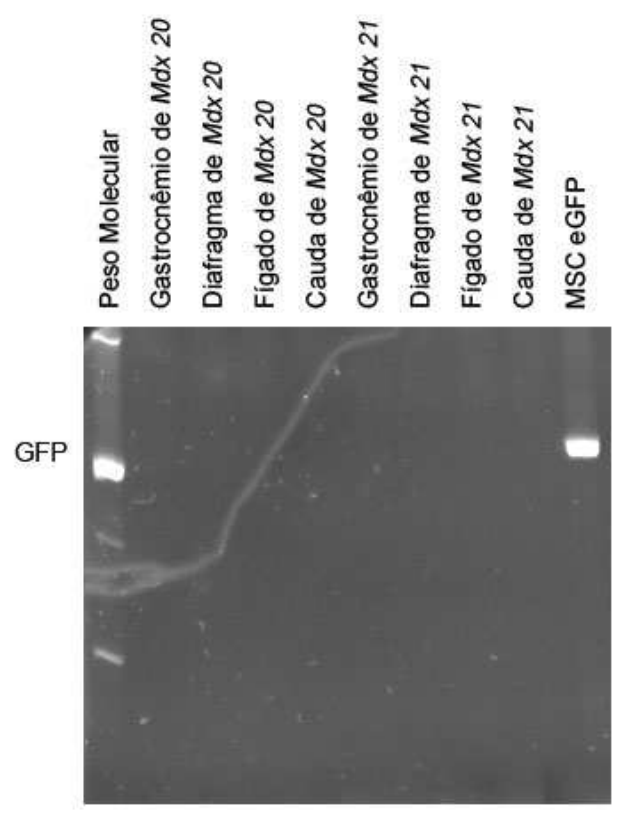

Figura 22: Reação de PCR do DNA dos diferentes tecidos dos camundongos do experimento 4, assim como seu controle positivo (células MSC eGFP), amplificados com primers específicos do gene eGFP.

Entretanto, neste experimento só conseguimos visualizar a presença do gene eGFP no controle positivo da reação, sugerindo a ausência das células injetadas nos tecidos avaliados.

\subsubsection{Experimento 5 - Injeção intramuscular de células MSC eGFP - Análise após curto período}

Para verificar a sensibilidade da metodologia no rastreamento do DNA das células injetadas, procedeu-se a implantação de células MSC eGFP de quarta passagem no músculo gastrocnêmio de camundongos $m d x$ (TABELA 8), que foram sacrificados e seus músculos analisados após 2 e 3 dias. 


\begin{tabular}{|c|c|c|c|}
\hline $\begin{array}{c}\text { Nome do } \\
\text { camundongo }\end{array}$ & $\begin{array}{c}\text { Tipo de célula } \\
\text { injetada }\end{array}$ & $\begin{array}{c}\text { Tempo após a } \\
\text { injeção (sacrifício) }\end{array}$ & Tecidos analisados \\
\hline$M d \times 22$ & MSC eGFP & 2 dias & Gastrocnêmio \\
\hline$M d \times 23$ & MSC eGFP & 3 dias & Gastrocnêmio \\
\hline
\end{tabular}

Tabela 8: Animais injetados intramuscularmente com células MSC eGFP de quarta passagem no experimento 5 .

\section{- Rastreamento do gene eGFP no músculo injetado e controle}

Neste experimento, conseguiu-se detectar a banda referente ao gene eGFP através de PCR (FIGURA 23), nos músculos injetados.

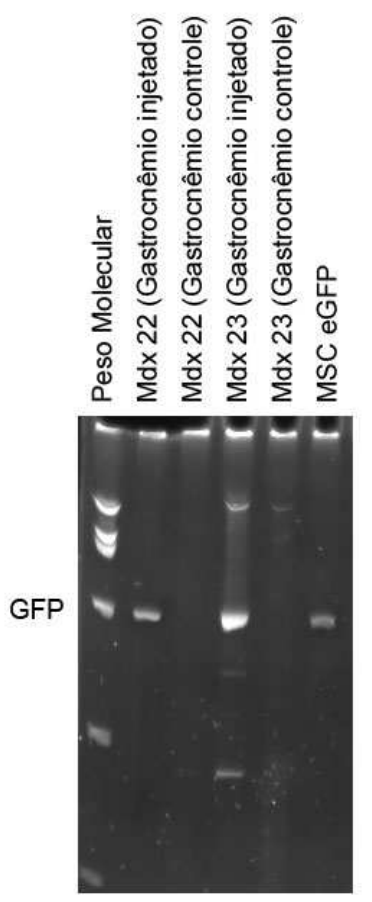

Figura 23: Reação de PCR do DNA dos músculos injetados e controles de camundongos do experimento 5, assim como seu controle positivo (células MSC eGFP), amplificados com primers específicos do gene eGFP. 
4.1.3.6 Experimento 6 - Injeções intramuscular e sistêmica de células MSC eGFP associadas à imunossupressão - Análise após diferentes períodos

Realizou-se ensaios de implantação de células em camundongos imunossuprimidos. Para isso, os animais receberam doses diárias de $1 \mathrm{mg} / \mathrm{kg}$ do imunossupressor FK-506 (Tracolimus SIGMA-ALDRICH) intraperitoneamente desde 1 dia antes da injeção das células até o dia da sua eutanásia, segundo descrito por NUNES et al. (2007). Realizou-se, então, a implantação de células MSC eGFP de quarta passagem, em músculo gastrocnêmio e na veia caudal de camundongos $m d x$ (TABELA 9), e esses animais foram sacrificados após 15 dias e 1 mês, e diferentes tecidos foram analisados.

\begin{tabular}{|c|c|c|c|}
\hline $\begin{array}{c}\text { Nome do } \\
\text { camundongo }\end{array}$ & $\begin{array}{c}\text { Tipo de célula } \\
\text { injetada }\end{array}$ & $\begin{array}{c}\text { Tempo após a } \\
\text { injeção (sacrifício) }\end{array}$ & $\begin{array}{c}\text { Tecido } \\
\text { analisado }\end{array}$ \\
\hline$M d x 24$ & MSC eGFP & 15 dias (local) & Gastrocnêmio \\
\hline$M d x 25$ & MSC eGFP & 1 mês (local) & Gastrocnêmio \\
\hline$M d x 26$ & MSC eGFP & 15 dias (sistêmico) & Gastrocnêmio \\
& & & Diafragma \\
& & 1 mês (sistêmico) & Fígado \\
& & & Cauda \\
\hline$M d x 27$ & MSC eGFP & & Diafragnêmio \\
& & & Fígado \\
& & & Cauda \\
\hline
\end{tabular}

Tabela 9: Camundongos injetados local e sistemicamente com células MSC eGFP quarta passagem no experimento 6 . 


\section{RESULTADOS}

- Rastreamento do gene eGFP nos músculos injetados e controles

Verificou-se que, mesmo os camundongos sendo imunossuprimidos, não se conseguiu localizar as células injetadas através de PCR para o gene GFP, sugerindo, mais uma vez, a sua eliminação (FIGURA 24).

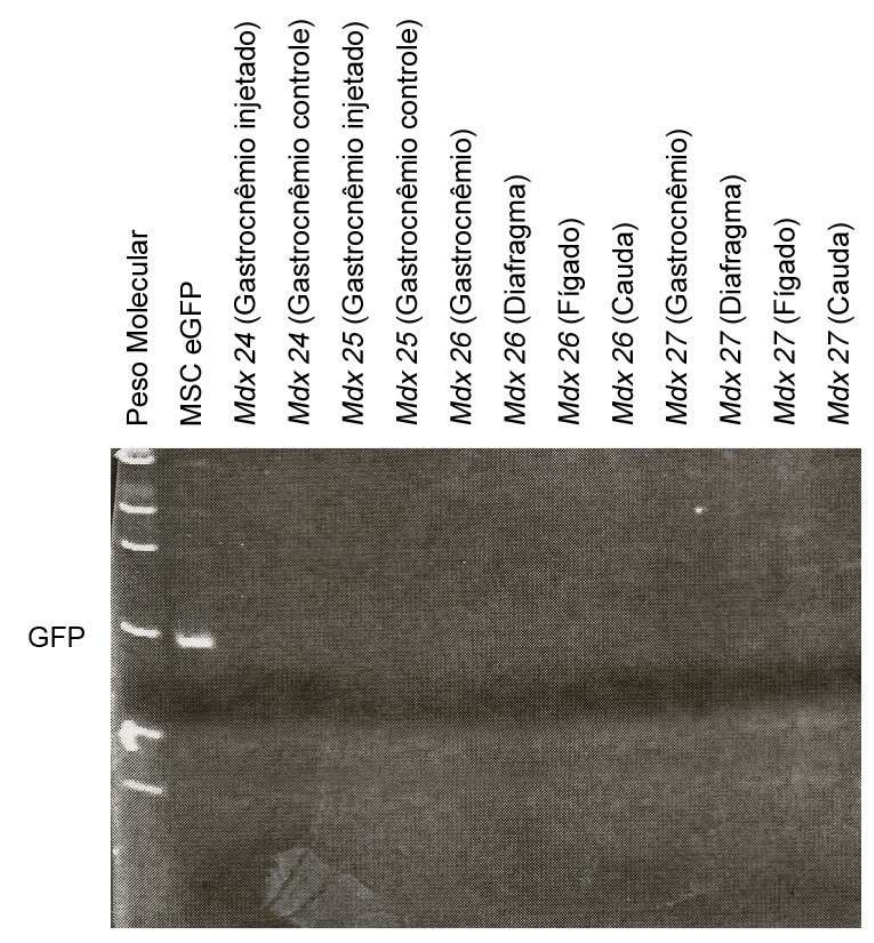

Figura 24: Reação de PCR do DNA dos músculos injetados e controles dos camundongos do experimento 6, assim como seu controle positivo (células MSC eGFP), amplificados com primers específicos do gene eGFP. 
4.1.3.7 Experimento 7 - Avaliação do micro-ambiente distrófico - Injeções intramusculares de células MSC eGFP em diferentes linhagens de camundongos normais

Realizou-se um experimento com a implantação de células MSC eGFP de quarta passagem em músculo gastrocnêmio de camundongos $F V B$ selvagens não expressando a proteína GFP e de camundongos C57black6 (TABELA 10). Esses animais foram sacrificados após diferentes tempos, e diversos tecidos foram analisados.

\begin{tabular}{|c|c|c|c|}
\hline $\begin{array}{c}\text { Nome do } \\
\text { camundongo }\end{array}$ & $\begin{array}{c}\text { Tipo de célula } \\
\text { injetada }\end{array}$ & $\begin{array}{c}\text { Tempo após a } \\
\text { injeção (sacrifício) }\end{array}$ & $\begin{array}{c}\text { Músculo } \\
\text { analisado }\end{array}$ \\
\hline$F V B 1$ & MSC eGFP & 2 dias & Gastrocnêmio \\
\hline$F V B 2$ & MSC eGFP & 7 dias & Gastrocnêmio \\
\hline$F V B 3$ & MSC eGFP & 1 mês & Gastrocnêmio \\
\hline$C 57$ black6 1 & MSC eGFP & 2 dias & Gastrocnêmio \\
\hline C57black6 2 & MSC eGFP & 7 dias & Gastrocnêmio \\
\hline C57black6 3 & MSC eGFP & 1 mês & Gastrocnêmio \\
\hline
\end{tabular}

Tabela 10: Camundongos injetados localmente com células MSC eGFP de quarta passagem no experimento 7 .

- Rastreamento do gene eGFP nos músculos injetados e controles

A presença de células com o gene GFP nos músculos injetados continuaram a ser observadas somente após 2 dias de injetadas (FIGURA 25). Como as células injetadas eram da própria linhagem do camundongo $F V B$, estes resultados começaram a indicar um possível efeito deletério da proteína GFP no músculo. 


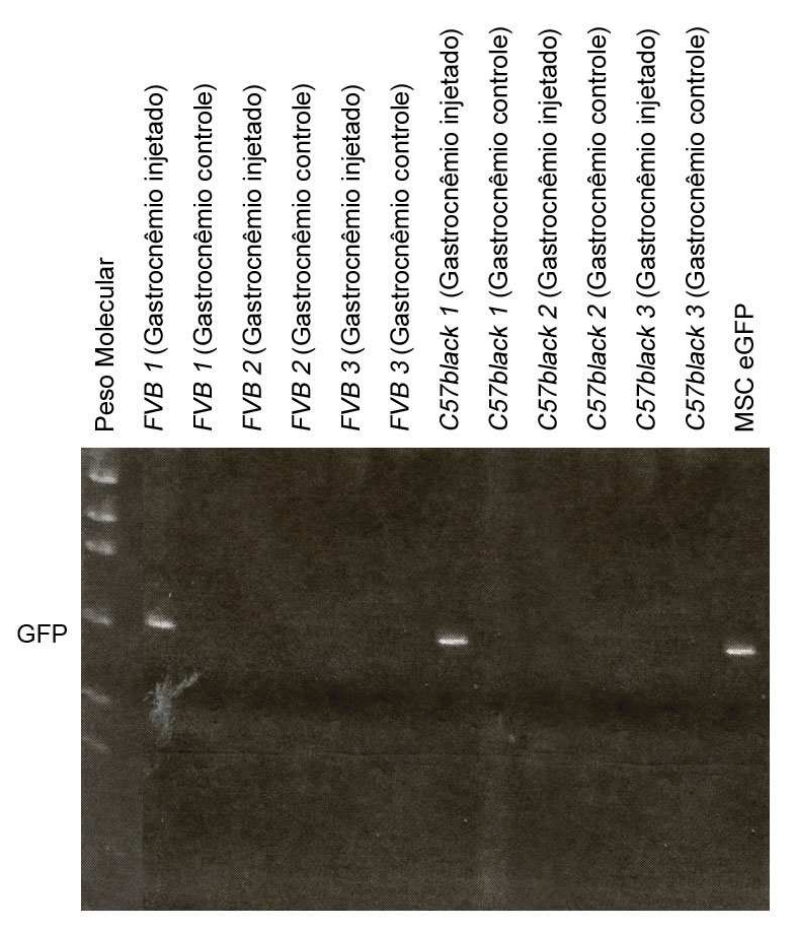

Figura 25: Reação de PCR do DNA dos músculos injetados e controles de camundongos do experimento 7, assim como seu controle positivo (células MSC eGFP), amplificados com primers específicos do gene eGFP. 


\subsection{Experimentos com células tronco embrionárias}

\subsubsection{Estabelecimento da metodologia de cultivo de células tronco embrionárias de camundongos}

Fibroblatos de camundongos foram irradiados e imediatamente cultivados em frascos de cultura gelatinizados com o objetivo de serem utilizados como FEEDER para o cultivo das células embrionárias (FIGURA 26).

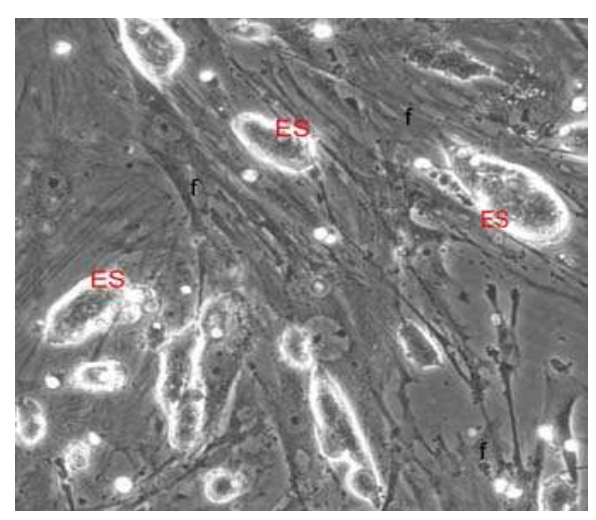

Figura 26: Cultura de células tronco embrionárias, em que (f) representa o FEEDER e (ES) são as células tronco embrionárias.

Nosso próximo passo foi de utilizá-las em experimentos de diferenciação in vitro e de implantação em camundongos $m d x$.

\subsubsection{Experimentos in vitro com células tronco embrionárias}

\subsubsection{Experimentos de diferenciação das células: Análise por Western blotting para a proteína distrofina}

Verificou-se primeiramente a capacidade das células ES de diferenciação espontânea por contato. Estas células foram mantidas em cultura, sem a realização de passagens, por um tempo maior que o recomendado para a sua manutenção em um estado indiferenciado. Posteriormente, 
tanto o FEEDER quanto as células embrionárias cultivadas foram submetidas ao processo de extração de proteínas (FIGURA 27).

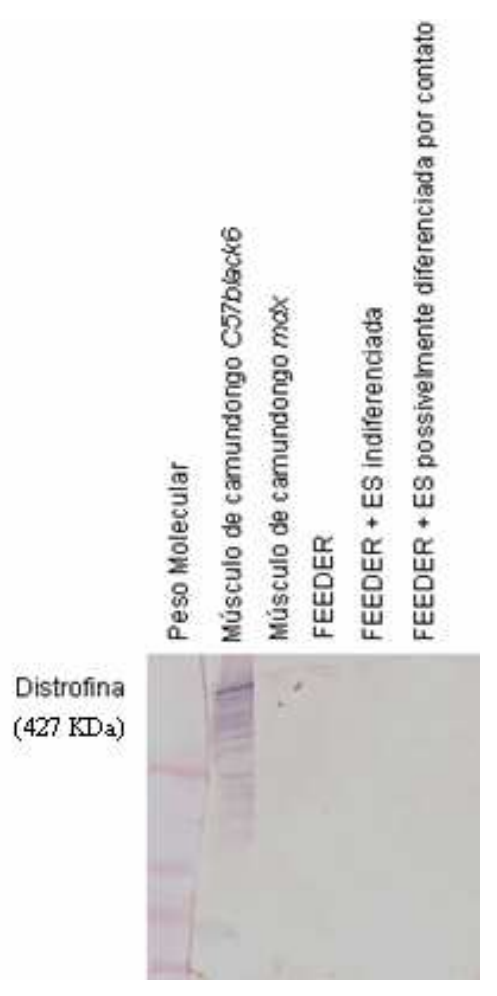

Figura 27: Western Blotting para a proteína distrofina das células embrionárias em possível processo de diferenciação espontânea por contato.

Entretanto, através desta técnica não se conseguiu identificar quantidade significativa de proteínas musculares, inclusive da distrofina.

\subsubsection{Experimentos de diferenciação das células ES e de co-cultura com mioblastos de camundongos mdx: Análise por PCR para proteínas de linhagem muscular}

A partir de então, utilizou-se as células ES do experimento anterior, além de células ES submetidas ao processo de diferenciação induzida através da formação de EB e de sua co- 
cultura com mioblastos de camundongos $m d x$, para extração de RNA, na tentativa de se verificar se elas passavam a expressar genes de desenvolvimento muscular (FIGURA 28).

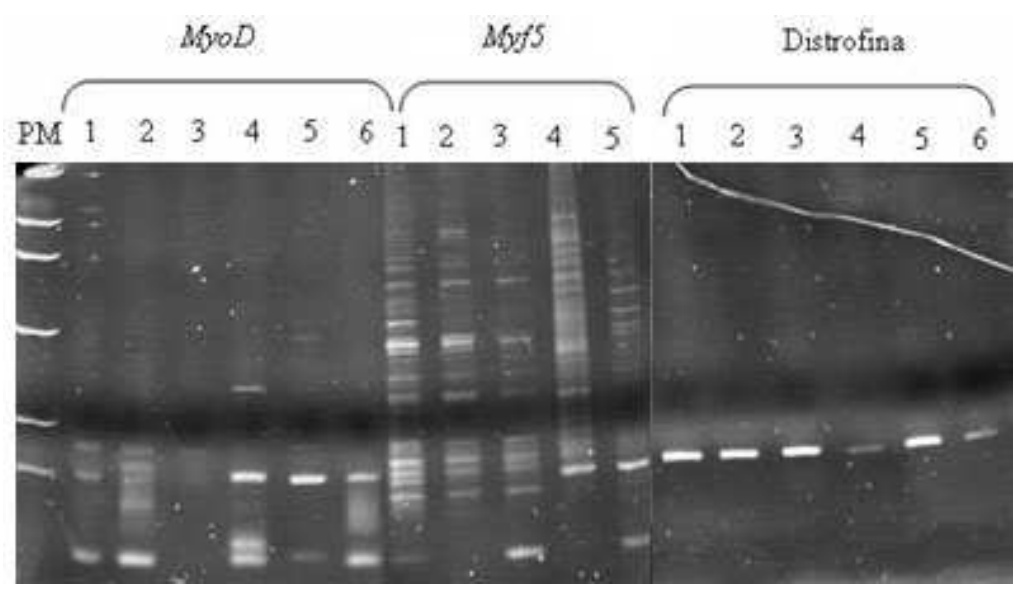

Figura 28: Reação de RT-PCR do cDNA células ES e EB, amplificados com primers específicos de proteínas de linhagens musculares. (1) ES, (2) EB + 1\% DMSO (1 dia), (3) EB + $1 \%$ DMSO (6 dias), (4) EB + mioblastos de camundongo $m d x$, (5) Músculo de camundongo C57black6 e (6) Músculo de camundongo $m d x$.

Aparentemente, se conseguiu diferenciar tanto as células ES quanto as células EB em tecido muscular, assim como ocorreu fusão destas células com mioblastos de camundongos $m d x$, uma vez que ambos começaram a expressar marcadores miogênicos. Isso comprova o potencial miogênico dessas células. 


\subsubsection{Experimentos in vivo: Implantação de células tronco embrionárias em camundongos} $m d x$

\subsubsection{Experimento 8 - Injeções intramusculares e sistêmicas de células tronco embrionárias}

Para os experimentos de implantes em camundongos $m d x$, as células embrionárias (ES) foram marcadas com corante vermelho, para facilitar a sua visualização no músculo injetado (FIGURA 29). Mas é importante ressaltar que esse corante vital se dilui quando há consecutivas divisões celulares.
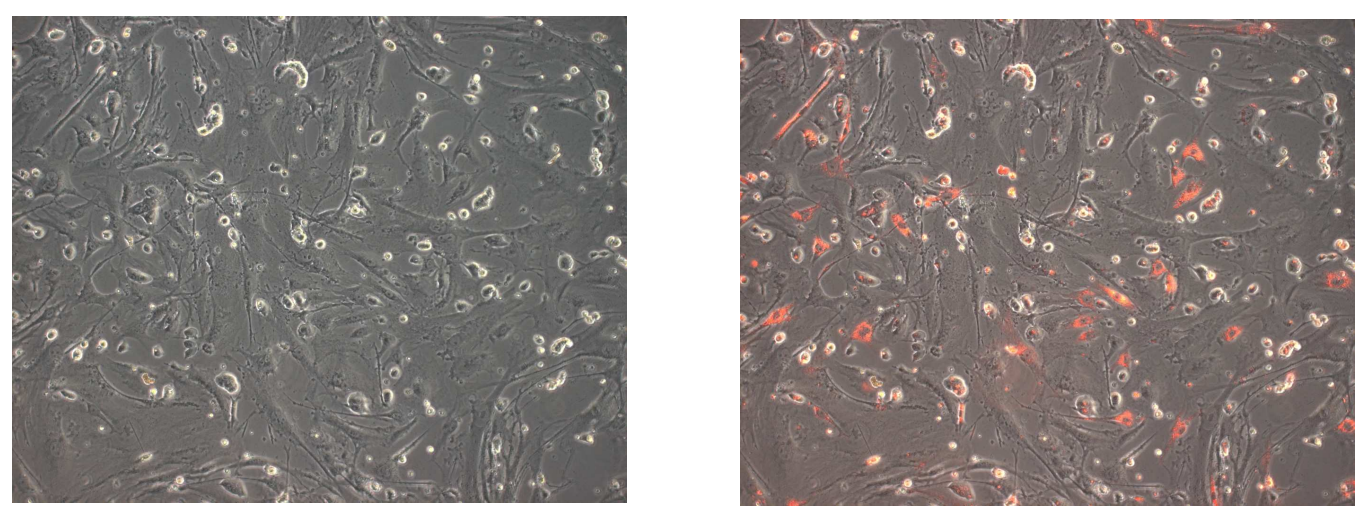

Figura 29: Células ES sobre a camada de FEEDER depois de serem coradas em vermelho.

Realizamos, então, um experimento com a implantação de ES em músculo gastrocnêmio e na veia caudal de camundongos $m d x$ não imunossuprimidos (TABELA 11) e imunossuprimidos (TABELA 12). Esses camundongos foram sacrificados em vários tempos após a injeção, foi analisada a presença de células marcadas em diferentes tecidos dos camundongos injetados, em que o número de sinais (+) é diretamente proporcional à intensidade da coloração vermelha nos músculos analisados e o sinal (-) representa ausência de marcação.. 


\begin{tabular}{|c|c|c|c|c|}
\hline $\begin{array}{c}\text { Nome do } \\
\text { camundongo }\end{array}$ & $\begin{array}{c}\text { Tipo de célula } \\
\text { injetada }\end{array}$ & $\begin{array}{c}\text { Tempo após a } \\
\text { injeção } \\
\text { (sacrifício) }\end{array}$ & $\begin{array}{l}\text { Músculos } \\
\text { analisados }\end{array}$ & $\begin{array}{l}\text { Análise da } \\
\text { coloração } \\
\text { vermelha }\end{array}$ \\
\hline$M d x 28$ & ES & 2 dias (local) & Gastrocnêmio & +++ \\
\hline$M d x 29$ & ES & 1 semana (local) & Gastrocnêmio & - \\
\hline$M d x 30$ & ES & 15 dias (local) & Gastrocnêmio & - \\
\hline$M d x 31$ & ES & 1 mês (local) & Gastrocnêmio & - \\
\hline$M d x 32$ & ES & $\begin{array}{c}2 \text { dias } \\
\text { (sistêmico) }\end{array}$ & $\begin{array}{c}\text { Gastrocnêmio } \\
\text { Diafragma } \\
\text { Fígado } \\
\text { Baço } \\
\text { Cauda }\end{array}$ & $\begin{array}{l}- \\
- \\
- \\
- \\
++\end{array}$ \\
\hline$M d x 33$ & ES & $\begin{array}{c}1 \text { semana } \\
\text { (sistêmico) }\end{array}$ & $\begin{array}{c}\text { Gastrocnêmio } \\
\text { Diafragma } \\
\text { Fígado } \\
\text { Baço } \\
\text { Cauda }\end{array}$ & $\begin{array}{l}- \\
- \\
- \\
- \\
-\end{array}$ \\
\hline$M d x 34$ & ES & $\begin{array}{c}15 \text { dias } \\
\text { (sistêmico) }\end{array}$ & $\begin{array}{c}\text { Gastrocnêmio } \\
\text { Diafragma } \\
\text { Fígado } \\
\text { Baço } \\
\text { Cauda }\end{array}$ & $\begin{array}{l}- \\
- \\
- \\
- \\
-\end{array}$ \\
\hline$M d x 35$ & ES & $\begin{array}{c}1 \text { mês } \\
\text { (sistêmico) }\end{array}$ & $\begin{array}{c}\text { Gastrocnêmio } \\
\text { Diafragma } \\
\text { Fígado } \\
\text { Baço } \\
\text { Cauda }\end{array}$ & $\begin{array}{l}- \\
- \\
- \\
- \\
-\end{array}$ \\
\hline
\end{tabular}

Tabela 11: Camundongos não imunossuprimidos injetados local e sistemicamente com células ES no experimento 8, e avaliação quantitativa da presença de células ES marcadas, através da 
verificação de coloração vermelha nos corte histológicos dos músculos e tecidos dos camundongos injetados.

\begin{tabular}{|c|c|c|c|c|}
\hline $\begin{array}{c}\text { Nome do } \\
\text { camundongo }\end{array}$ & $\begin{array}{c}\text { Tipo de célula } \\
\text { injetada }\end{array}$ & $\begin{array}{c}\text { Tempo após a } \\
\text { injeção } \\
\text { (sacrifício) }\end{array}$ & $\begin{array}{l}\text { Músculos } \\
\text { analisados }\end{array}$ & $\begin{array}{c}\text { Análise da } \\
\text { coloração } \\
\text { vermelha }\end{array}$ \\
\hline$M d x 36$ & ES & 1 semana (local) & Gastrocnêmio & +++++ \\
\hline$M d x 37$ & ES & 15 dias (local) & Gastrocnêmio & +++ \\
\hline$M d x 38$ & ES & 1 mês (local) & Gastrocnêmio & ++ \\
\hline$M d x 39$ & ES & $\begin{array}{c}1 \text { semana } \\
\text { (sistêmico) }\end{array}$ & $\begin{array}{c}\text { Gastrocnêmio } \\
\text { Diafragma } \\
\text { Fígado } \\
\text { Baço } \\
\text { Cauda }\end{array}$ & $\begin{array}{l}- \\
- \\
- \\
- \\
++\end{array}$ \\
\hline$M d x 40$ & ES & $\begin{array}{c}15 \text { dias } \\
\text { (sistêmico) }\end{array}$ & $\begin{array}{c}\text { Gastrocnêmio } \\
\text { Diafragma } \\
\text { Fígado } \\
\text { Baço } \\
\text { Cauda }\end{array}$ & $\begin{array}{l}- \\
- \\
- \\
- \\
++\end{array}$ \\
\hline
\end{tabular}

Tabela 12: Camundongos imunossuprimidos injetados local e sistemicamente com células ES no experimento 8, e avaliação quantitativa da presença de células ES marcadas, através da verificação de coloração vermelha nos corte histológicos dos músculos e tecidos dos camundongos injetados. 


\section{- Avaliação dos músculos injetados e controles}

Em 2 camundongos injetados com células ES, em que se utilizou a imunossupressão $(M d x$ 37 e $M d x 38$ ), observou-se que, com o passar do tempo, as suas patas injetadas apresentavam-se gradativamente com o volume aumentado e a necrópsia revelou grande aumento dos músculos na região injetada (FIGURA 30).
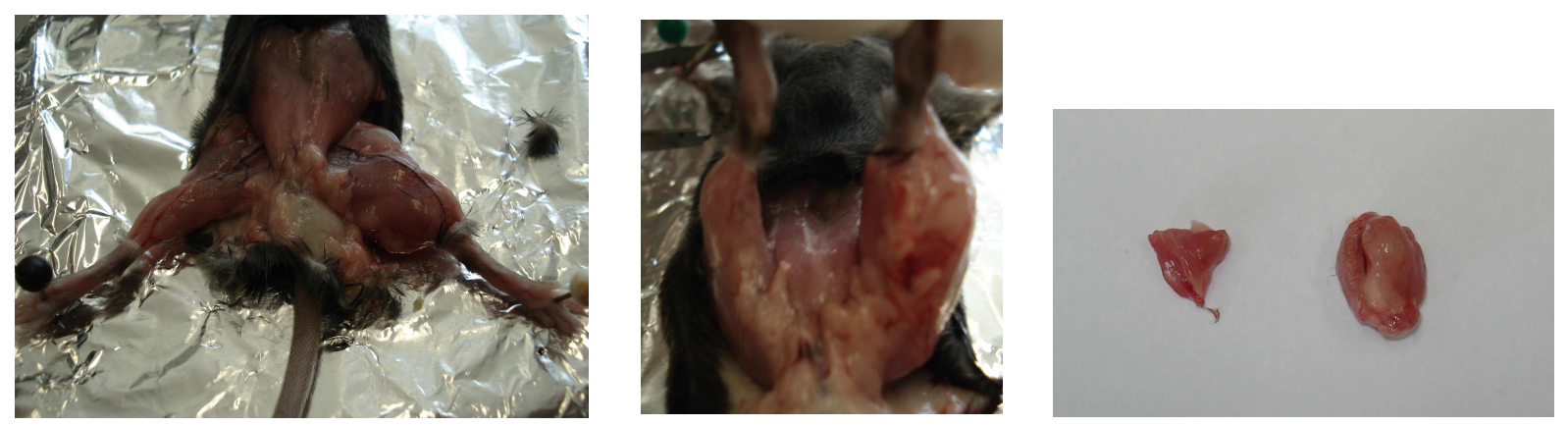

Figura 30: Comparação de tamanho entre o músculo gastrocnêmio do camundongo $M d x 37$ injetado com células ES (pata esquerda) e o seu músculo controle (pata direita).

- Avaliação dos cortes histológicos dos músculos injetados e controles

No corte histológico do músculo do camundongo $M d x$ 37, identificou-se diversos focos marcados de vermelho compatíveis com as células injetadas, evento não observado no músculo controle (FIGURA 31). 


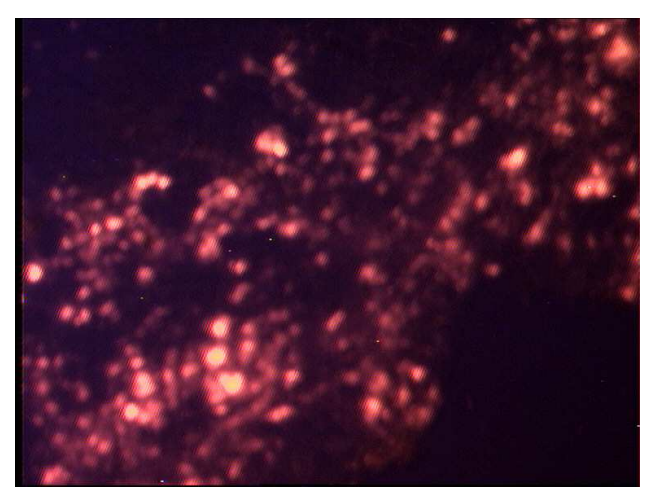

Figura 31: Músculo gastrocnêmio injetado do camundongo $M d x$ 37, mostrando focos marcados de vermelho, o que pode significar a presença das células injetadas (Aumento X 200).

Como pode-se observar nas TABELAS 11 E 12, não foi possível identificar sinal da presença das células ES injetadas nos camundongos não imunossuprimidos (FIGURA 32b), com exceção do músculo do camundongo sacrificados após 2 dias (Mdx 28) (FIGURA 32a).
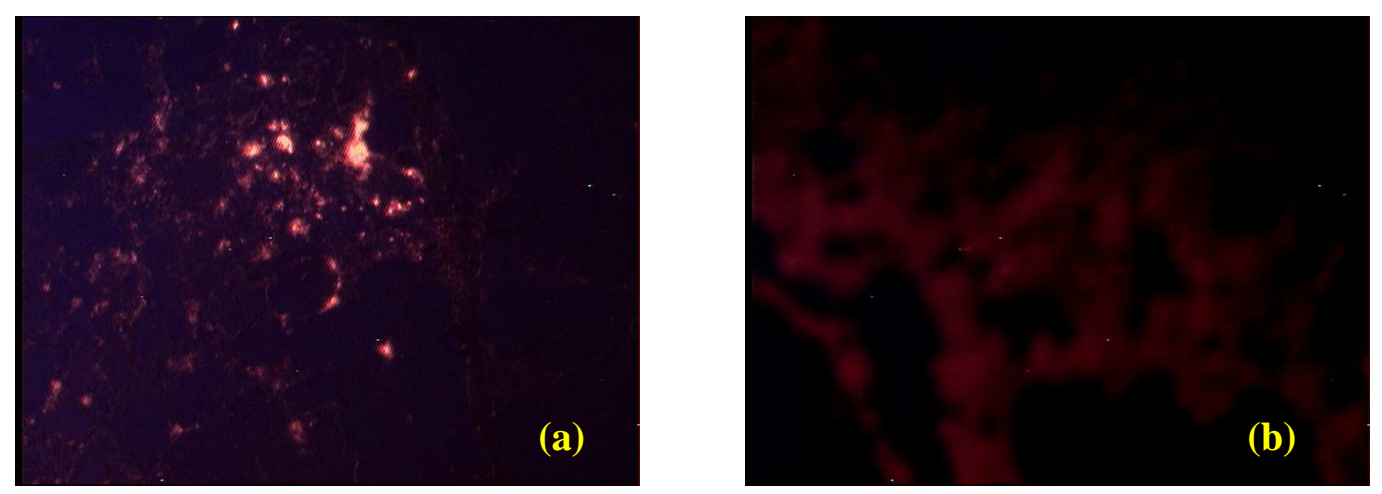

Figura 32: Corte histológico do músculo gastrocnêmio injetado com células ES dos camundongos (a) $M d x 28$ e (b) $M d x$ 29, mostrando a diferença entre a presença de coloração vermelha (Aumento X 200).

Também notou-se que nos camundongos injetados sistemicamente só observou-se a presença de marcação vermelha na região da cauda por onde essas células foram introduzidas (FIGURA 33). 


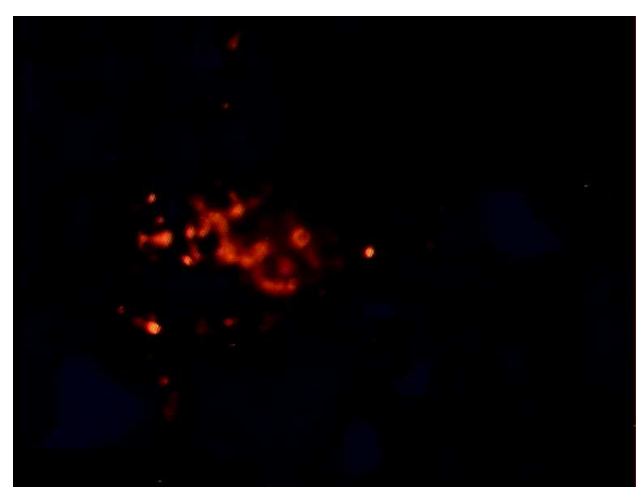

Figura 33: Corte histológico da cauda do camundongo $M d x 39$, injetado sistemicamente com células ES (Aumento X 200).

\section{- Análise morfológica dos músculos injetados}

Os cortes histológicos foram analisadas através da coloração de hematoxilina-eosina, em que observou-se diferença na citoarquitetura das fibras musculares dos músculos injetados dos camundongos $M d x 37$ e $M d x$ 38, que se apresentavam com focos de degeneração intensa (FIGURA 34) e infiltração de diversos tipos de células imaturas, dentre elas, algumas com aspecto de fibroblastos e outras estreladas (FIGURA 35).
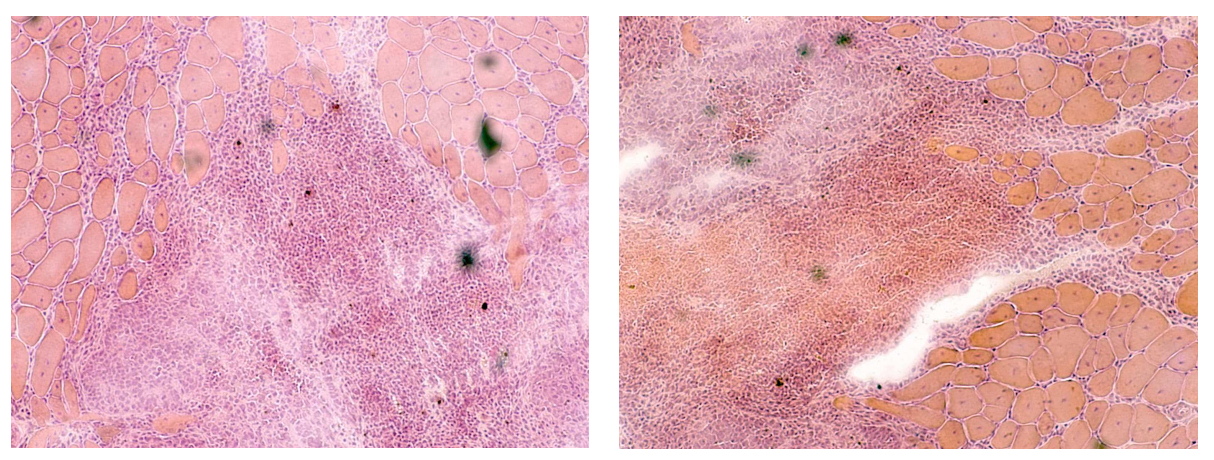

Figura 34: Corte histológico de músculo gastrocnêmio injetado do camundongo $M d x 37$, em que se observa a presença de focos de degeneraão intensa (Aumento X 100). 

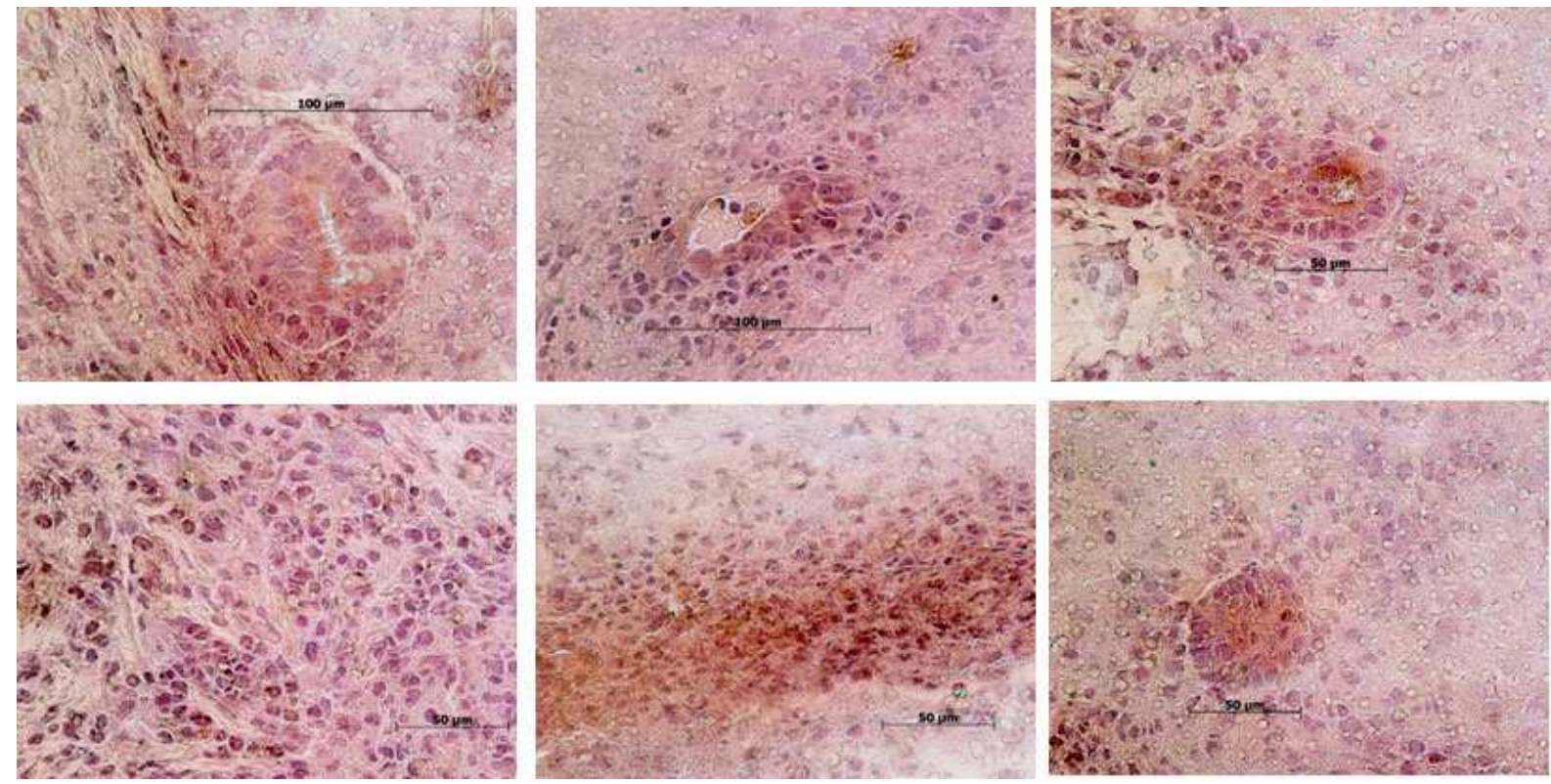

Figura 35: Tecido hipercelular presente no corte histológico do músculo gastrocnêmio injetado do camundongo de $M d x 37$ (Aumento X 400).

- Análise imunohistoquímica para proteína distrofina dos músculos injetados e controles

Reagiu-se cortes histológicos de músculos de camundongos injetados e controles com o anticorpo anti-distrofina. Somente observamos a presença de uma formação, parecida com novas fibras musculares, positivas para distrofina, no músculo injetado do camundongo $M d x 37$ no meio da região com predomínio de infiltração (FIGURA 36). 


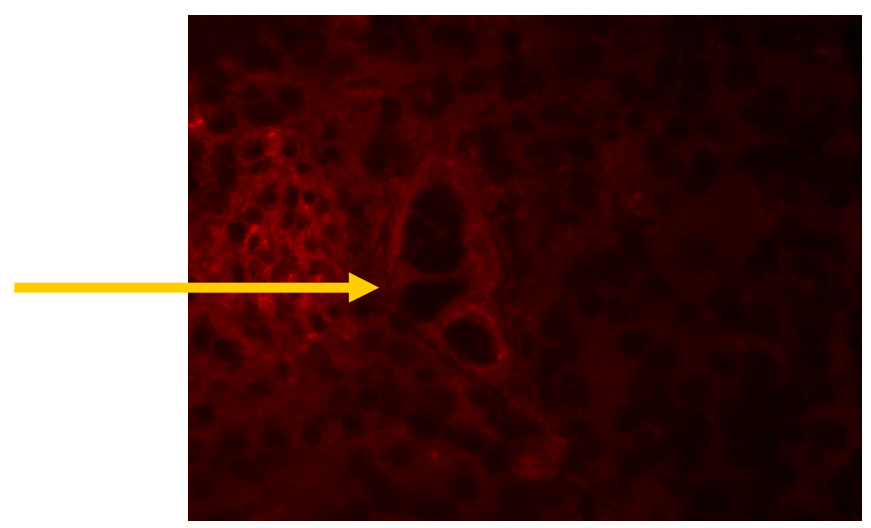

Figura 36: Reação de imunofluorescência para a proteína distrofina em corte histológico do músculo gastrocnêmio injetado do camundongo $M d x$ 37, mostrando a presença de uma possível fibra muscular em formação (Aumento X 200)..

- Análise imunohistoquímica para a proteína miosina fetal nos músculos injetados e controles

Para se verificar se no corte histológico do músculo injetado do camundongo $M d x 37$ havia focos de regeneração e de formação de fibras novas expressando distrofina, reagiu-se o músculo injetado com o anticorpo anti-miosina fetal. Porém, não se observou nenhum sinal de marcação positiva para este anticorpo, na mesma região descrita acima (FIGURA 37).

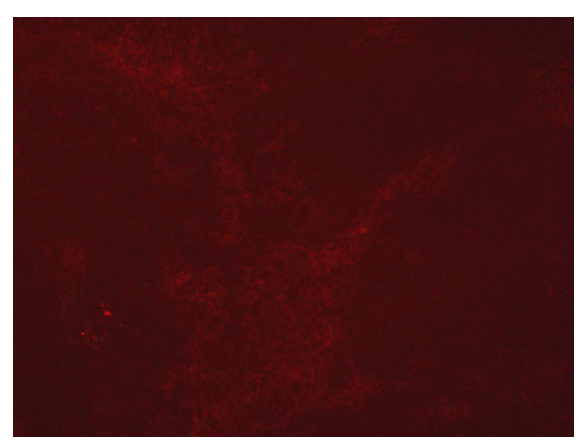

Figura 37: Reação de imunofluorescência para a proteína miosina fetal de cortes histológicos do músculo do camundongo $M d x$ 37, mostrando ausência de marcação (Aumento X 200). 
Verificou-se que, nos cortes histológicos dos músculos dos camundongos injetados com células ES apresentavam um padrão de reação positivo para proteína miosina fetal em alguns focos de feixes musculares, característico da reação de cortes musculares de camundongos $m d x$ (FIGURA 38).
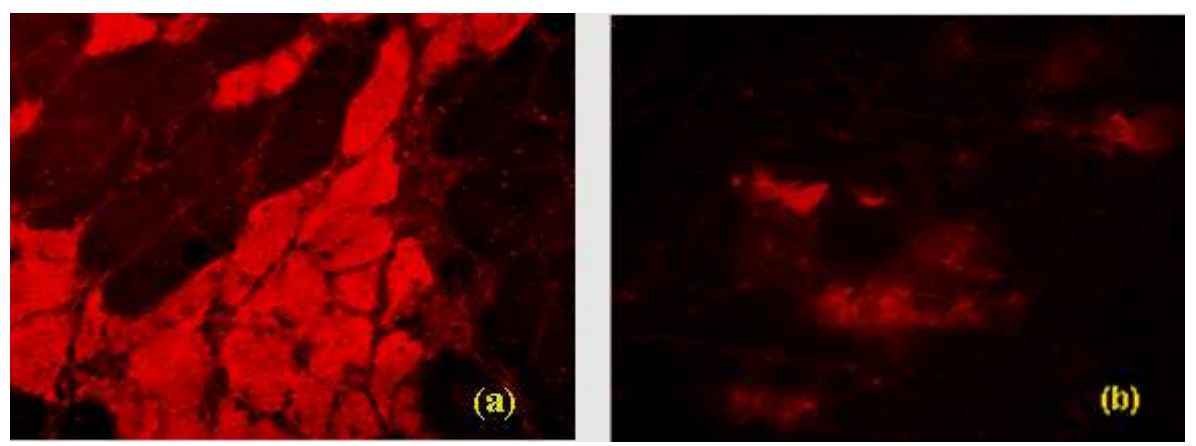

Figura 38: Reação de imunofluorescência para proteína miosina fetal em cortes histológicos de músculos de (a) camundongo $m d x$ não injetado e (b) camundongo $M d x 37$ (Aumento X 200).

- Análise por Western Blotting para a proteína distrofina nos músculos injetados e controles

Correu-se blots dos extratos dos músculos dos camundongos injetados no experimento 8, e reagiu-se com anticorpo anti-distrofina (FIGURAS 39 e 40), mas não se verificou a expressão da proteína nos tecidos analisados. 


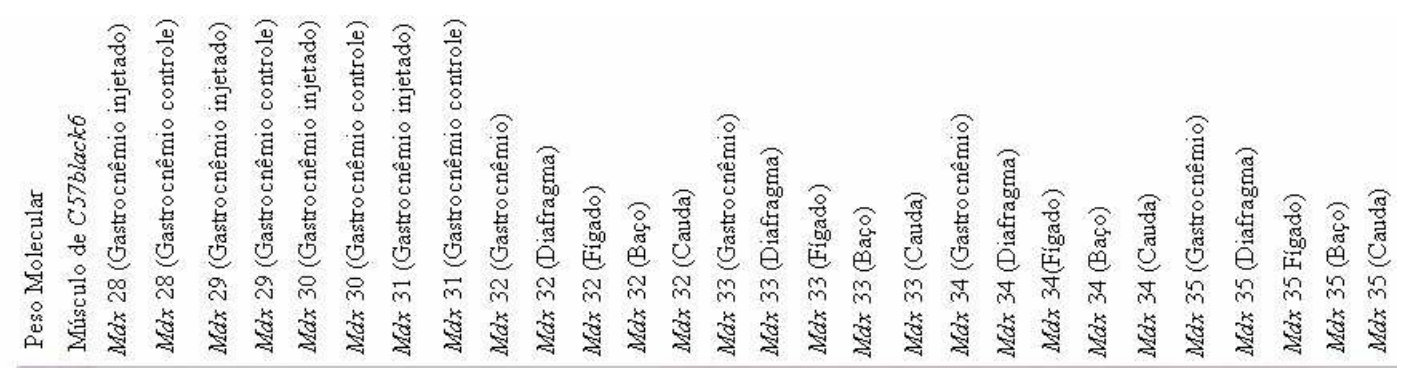

Distrofina

$(427 \mathrm{KDa})$

Figura 39: Western Blotting para a proteína distrofina nos extratos dos músculos dos camundongos não imunossuprimidos injetados local e sistemicamente com células ES no experimento 8 .
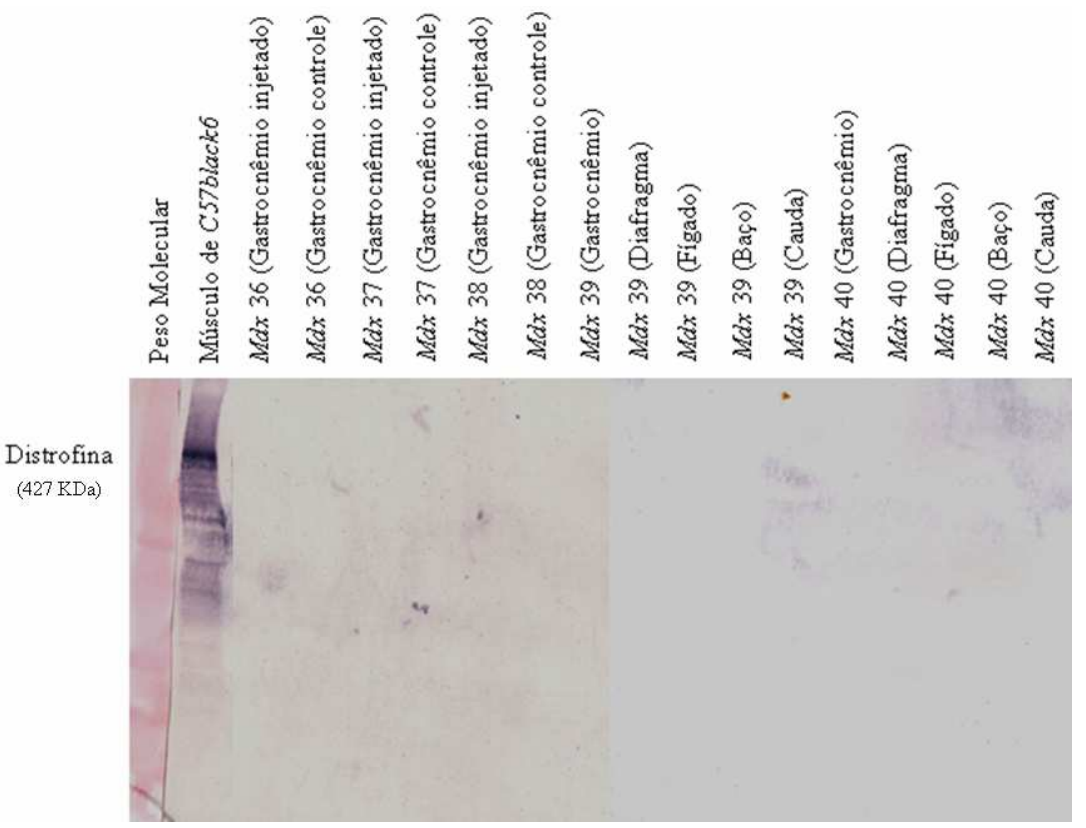

Figura 40: Western Blotting para a proteína distrofina nos extratos dos músculos dos camundongos imunossuprimidos injetados local e sistemicamente com células ES no experimento 8 . 
- Análise dos músculos injetados e controles por PCR com marcadores específicos de cada linhagem de camundongo

Utilizou-se marcadores de microssatélites próprios de cada linhagem de camundongo (camundongos 129 e $m d x$ ) para que se pudesse rastrear as células injetadas através de PCR (FIGURAS 41 e 42). Por esta técnica pode-se verificar a presença das células ES somente no músculo injetado do camundongo $M d x 37$, em que aparecem a banda de peso molecular correspondente ao camundongo $m d x(121 \mathrm{pb})$ e a banda de maior peso molecular (142 pb) das células ES (FIGURA 42).

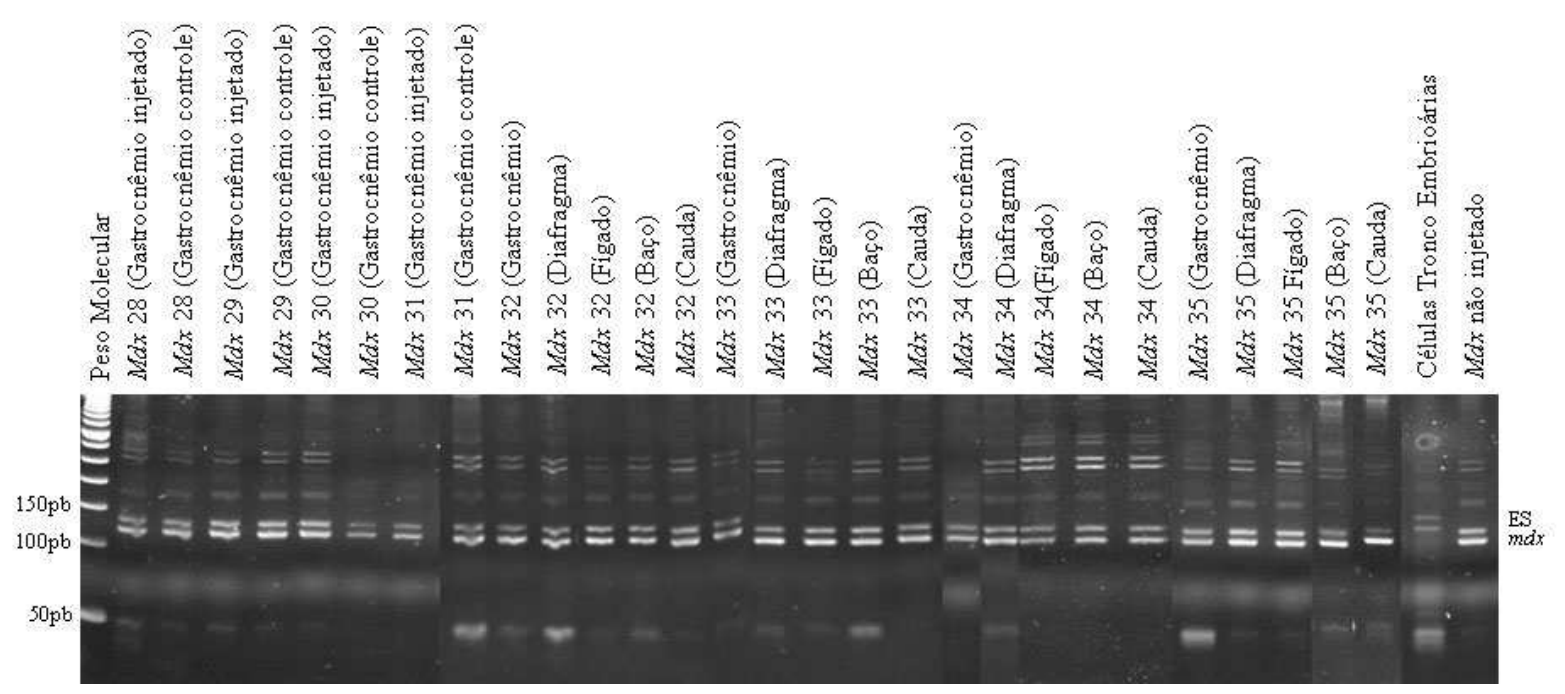

Figura 41: Reação de PCR do DNA dos músculos injetados e controles de camundongos não imunossuprimidos injetados local e sistemicamente com células ES no experimento 8, amplificados com primers de marcadores específicos de cada linhagem de camundongo. A banda de menor peso molecular $(121 \mathrm{pb})$ representa o DNA do camundongo $m d x$, enquanto a banda de maior peso molecular (142 pb) representa o DNA das células ES. 


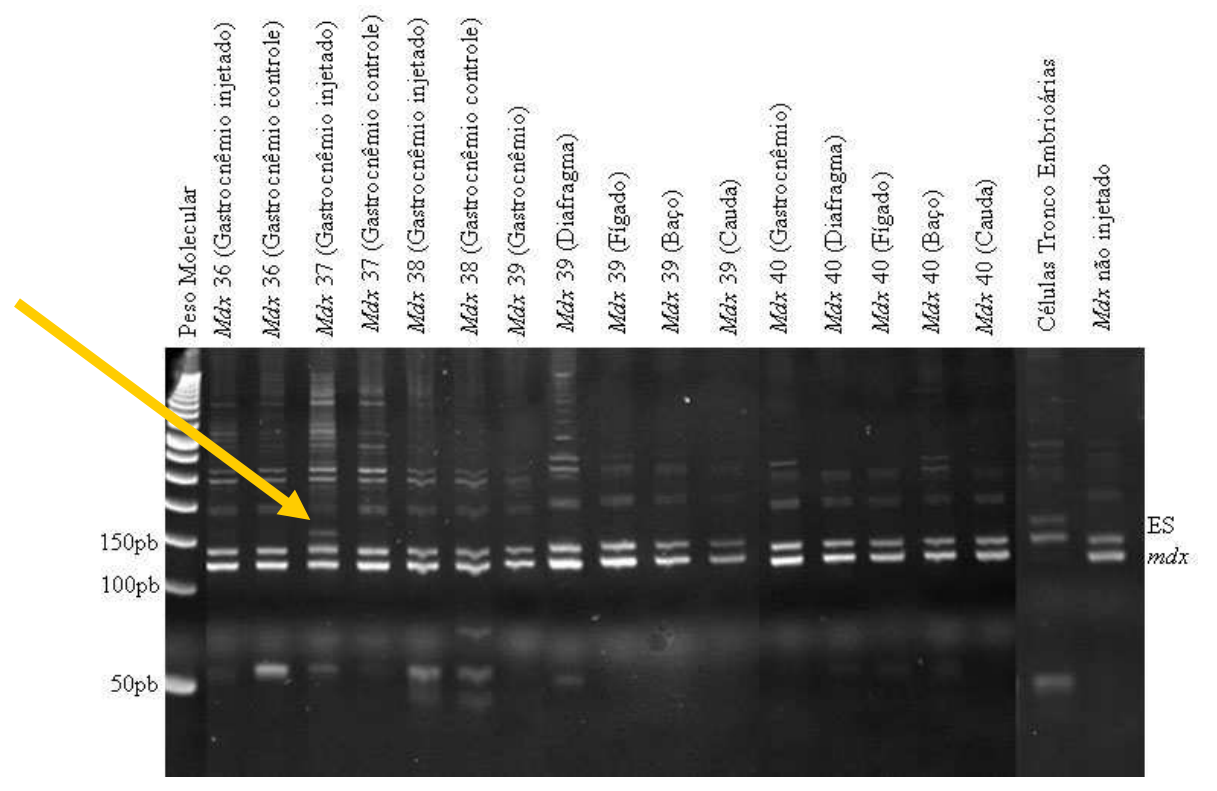

Figura 42: Reação de PCR do DNA dos músculos injetados e controles de camundongos imunossuprimidos injetados local e sistemicamente com células ES no experimento 8, amplificados com primers de marcadores específicos de cada linhagem de camundongo. A banda de menor peso molecular (121 pb) representa o DNA do camundongo $m d x$, enquanto a banda de maior peso molecular (142 pb) representa o DNA das células ES.

Para se verificar o quanto esta reação foi sensível à quantidade de DNA de células ES presentes no músculo injetado, fez-se um teste de quantificação em gel misturando-se quantidades fixadas de DNA de camundongos $m d x$ não injetados com DNA de células ES. Verificou-se que se conseguiu identificar as células ES até a sua concentração de pelo menos 30\% pela presença das 3 bandas relativas aos marcadores (FIGURA 43). 


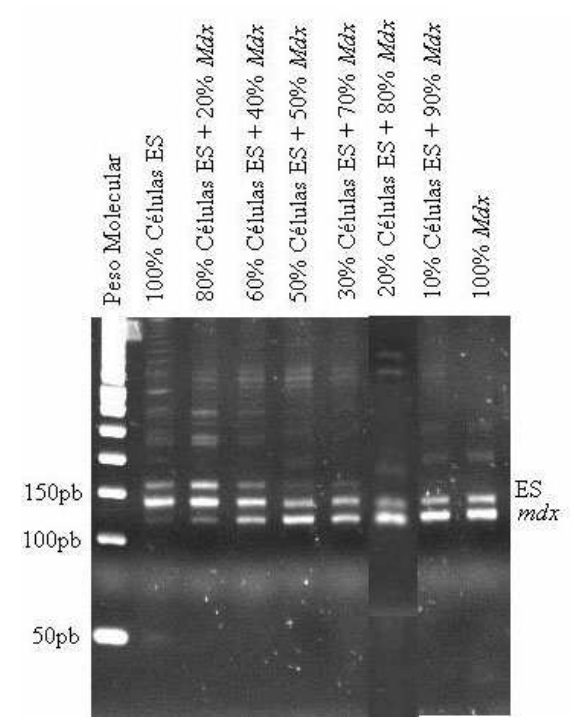

Figura 43: Reação de PCR da mistura de quantidades pré-estabelecidas do DNA dos músculos de camundongos $m d x$ não injetados com DNA de células ES, amplificados com primers de marcadores específicos de cada linhagem, mostrando que se conseguiu identificar até $10 \%$ de células depois de injetadas no músculo de camundongos $m d x$, pela presença das 3 bandas relativas aos marcadores.

Este resultado significou que se houvesse menos que 30\% de células ES injetadas no tecido analisado, esta técnica não seria capaz de identificar. Portanto, o camundongo $M d x 37$ apresenta em sua pata injetada, cerca de $30 \%$ de células ES.

\subsubsection{Experimento 9 - Injeções intramusculares e sistêmicas de células de Corpos} Embrióides

Conseguiu-se gerar mioblastos a partir das células tronco embrionárias tratando os Corpos Embrióides (EB) com 1\% de DMSO durante 5 dias (FIGURA 44a), o que levou à formação de clusters de células expressando a proteína desmina (FIGURA 44b). 

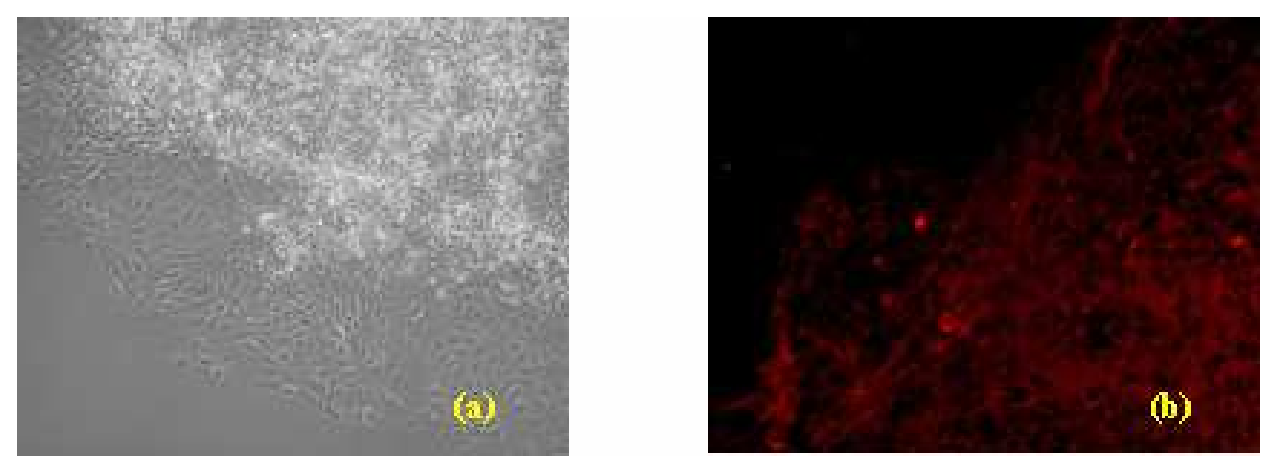

Figura 44: (a) Mioblastos (Aumento X 100) e (b) miotubos gerados a partir da prédiferenciação de células ES, marcados com a proteína desmina (Aumento X 400).

A partir disso, realizamos um experimento com a implantação de células de Corpos Embrióides em músculo gastrocnêmio e na veia caudal de camundongos $m d x$ imunossuprimidos (TABELA 13) e esses animais foram sacrificados em vários tempos após a injeção, e diferentes tecidos foram analisados. Os corpos embrióides foram dissociados e essas células prédiferenciadas foram marcadas com corante vermelho e injetadas. 


\begin{tabular}{|c|c|c|c|}
\hline $\begin{array}{c}\text { Nome do } \\
\text { camundongo }\end{array}$ & $\begin{array}{c}\text { Tipo de célula } \\
\text { injetada }\end{array}$ & $\begin{array}{c}\text { Tempo após a } \\
\text { injeção (sacrifício) }\end{array}$ & $\begin{array}{l}\text { Músculos } \\
\text { analisados }\end{array}$ \\
\hline$M d x 41$ & $\mathrm{~EB}$ & 1 mês (local) & Gastrocnêmio \\
\hline$M d x 42$ & EB & 1 mês (local) & Gastrocnêmio \\
\hline$M d x 43$ & EB & 2 meses (local) & Gastrocnêmio \\
\hline$M d x 44$ & EB & 2 meses (local) & Gastrocnêmio \\
\hline$M d x 45$ & $\mathrm{~EB}$ & $\begin{array}{c}1 \text { mês } \\
\text { (sistêmico) }\end{array}$ & $\begin{array}{c}\text { Gastrocnêmio } \\
\text { Diafragma } \\
\text { Fígado } \\
\text { Baço } \\
\text { Cauda }\end{array}$ \\
\hline$M d x 46$ & $\mathrm{~EB}$ & $\begin{array}{c}2 \text { meses } \\
\text { (sistêmico) }\end{array}$ & $\begin{array}{c}\text { Gastrocnêmio } \\
\text { Diafragma } \\
\text { Fígado } \\
\text { Baço } \\
\text { Cauda }\end{array}$ \\
\hline
\end{tabular}

Tabela 13: Camundongos imunossuprimidos injetados local e sistemicamente com células originárias dos EB no experimento 9 ..

- Análise imunohistoquímica para a proteína distrofina nos músculos injetados e controles

Realizou-se a análise dos cortes histológicos para se verificar a presença de células originadas dos corpos embrióides marcados de vermelho identificadas no experimento 8, mas não se pode observar marcação compatível com a presença das células no tecido injetado. Então, reagiu-se cortes histológicos de músculos controles e injetados dos camundongos do experimento 9 com o anticorpo anti-distrofina. A partir deles, observou-se um pouco de marcação positiva para distrofina em algumas fibras musculares de cortes de camundongos injetados localmente, o que pode representar um resultado mais significativo (FIGURA 45). 


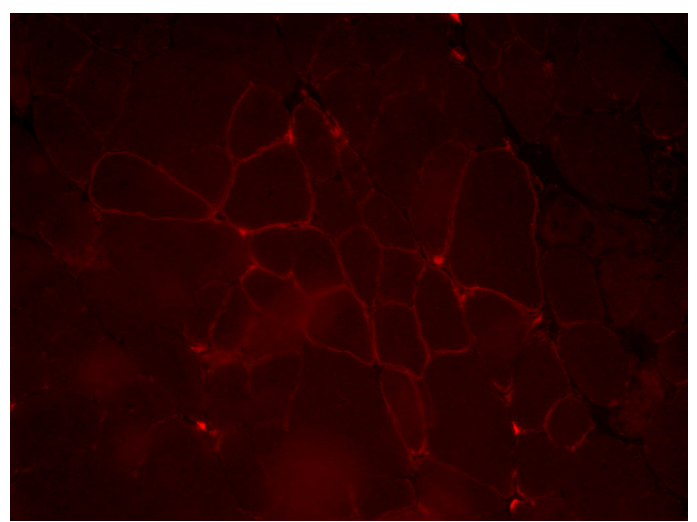

Figura 45: Reação de imunofluorescência para a proteína distrofina em cortes histológicos do músculo gastrocnêmio do camundongo Mdx 43 (Aumento X 200).

- Análise por Western Blotting da proteína distrofina nos músculos injetados e controles

Também correu-se 1 blot dos extratos dos músculos dos camundongos injetados no experimento 9, e reagiu-se com anticorpo anti-distrofina (FIGURA 46), a fim de se verificar se a marcação proveniente da imunohistoquímica era representativa. No entanto, não se observou a expressão da proteína nos tecidos analisados por esta técnica. 


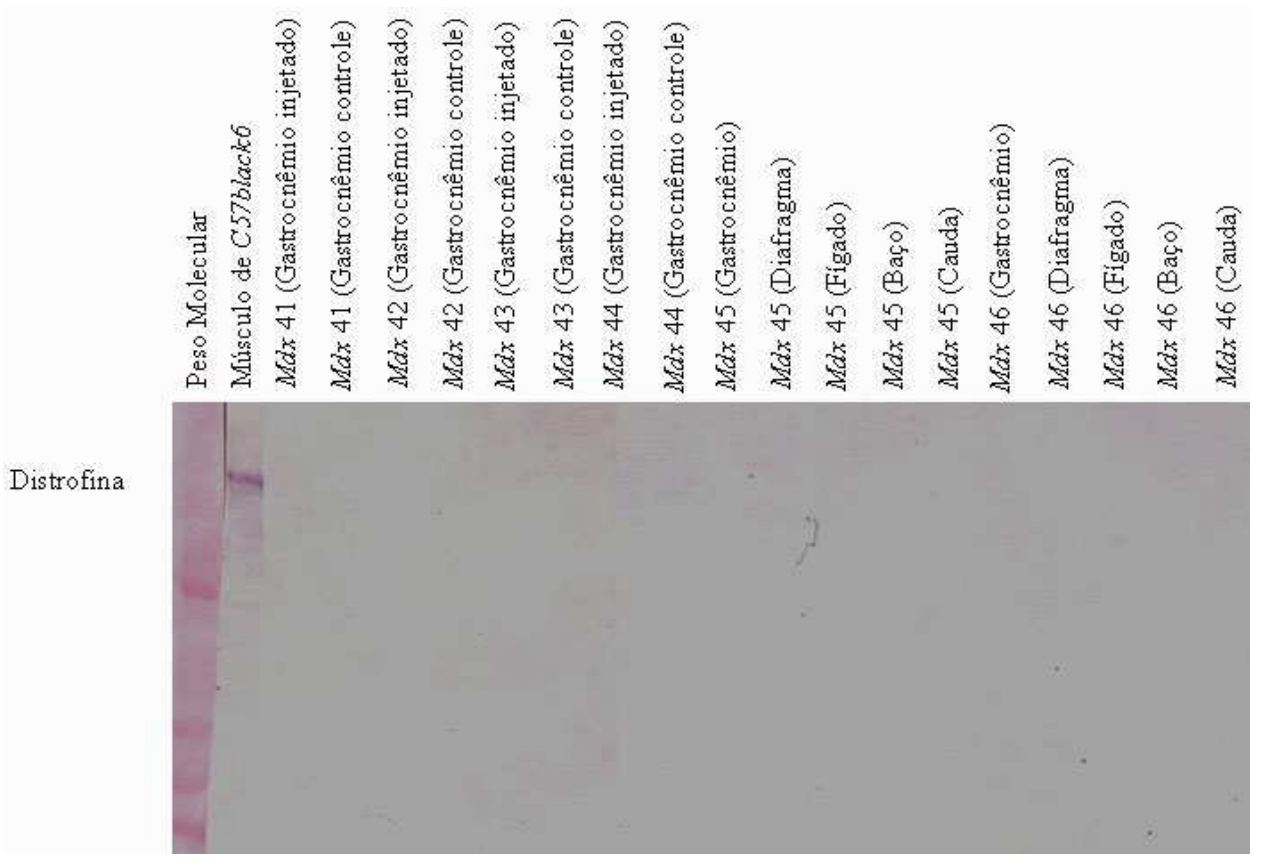

Figura 46: Western Blotting para a proteína distrofina nos extratos dos músculos dos camundongos imunossuprimidos injetados local e sistemicamente com EB no experimento 9.

- Análise através de PCR dos músculos injetados e controles: Reação com marcadores específicos de cada linhagem

Além disso, também utilizamos os marcadores de microssatélites próprios de cada uma das linhagem de camundongo, entretanto não encontramos presença de células ES nas amostras analisadas (FIGURA 47). 


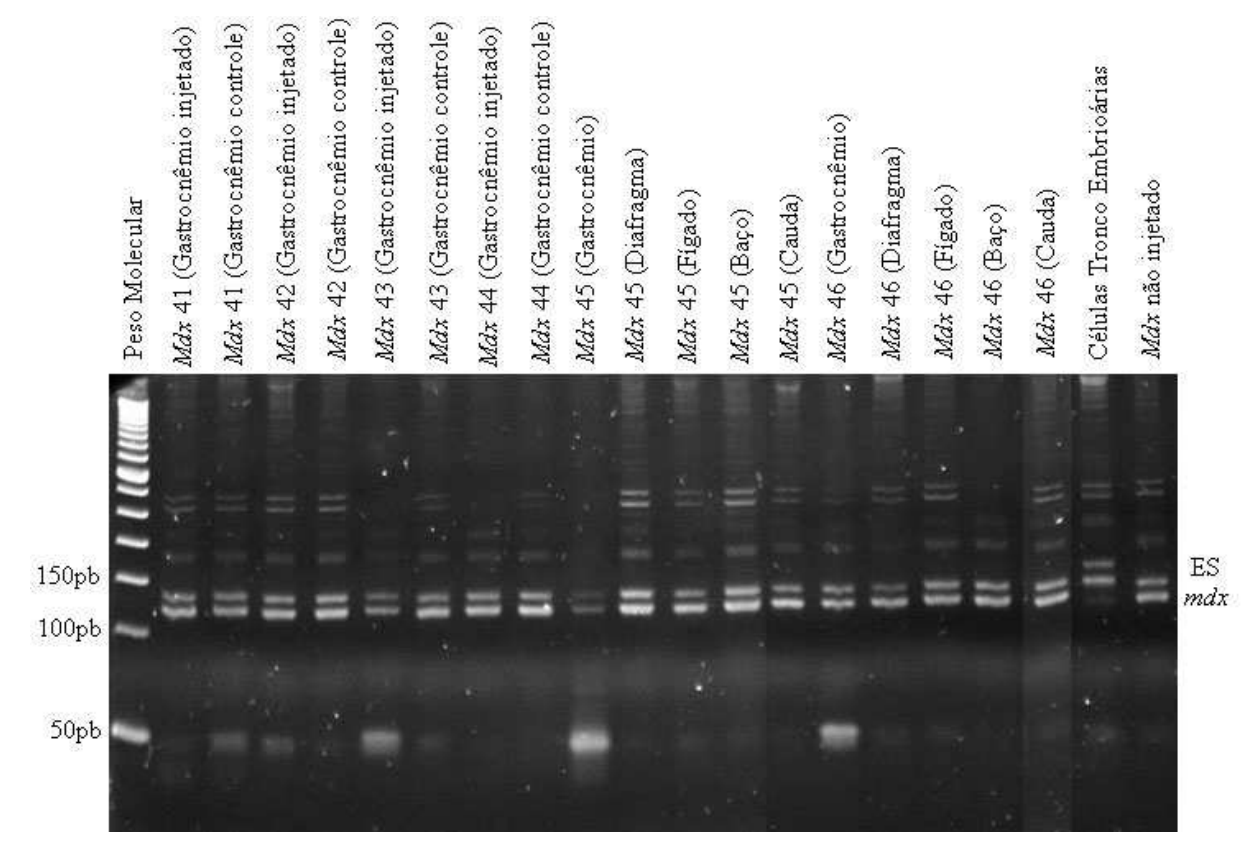

Figura 47: Reação de PCR do DNA dos músculos injetados e controles de camundongos imunossuprimidos injetados local e sistemicamente com EB no experimento 9, amplificados com primers de marcadores específicos de cada linhagem de camundongo. A banda de menor peso molecular $(121 \mathrm{pb})$ representa o DNA do camundongo $m d x$, enquanto a banda de maior peso molecular (142 pb) representa o DNA das células ES. 
5. DISCUSSÃO 
A terapia com células tronco vem ganhando um grande destaque, pois o transplante destas células em indivíduos afetados pode potencialmente corrigir diferentes deficiências e lesões. As vantagens desta metodologia se embasam nas evidências de que um pequeno número de células seria suficiente para se obter um efeito terapêutico. Diferentes sinais podem mobilizá-las e diferenciá-las diretamente em células da linhagem de tecidos específicos, e assim, poderiam corrigir danos devido a traumas, fraturas, necrose, tumores, ou defeitos genéticos (POUNTOS \& GIANNOUDIS, 2005). Estas características levaram a realização de diversos testes do potencial terapêutico dessas células no tratamento da Distrofia Muscular de Duchenne, em que, nos indivíduos afetados ocorre a ausência da proteína distrofina. O músculo danificado promoveria desta forma, a mobilização das células tronco, seu direcionamento para o tecido lesado, sua diferenciação em células musculares, levando à regeneração das fibras degeneradas (FERRARI et al., 1998). Para se corrigir o fenótipo distrófico, no entanto, as células transplantadas devem ser normais, pois ao se fundirem com as fibras musculares distróficas já existentes, irão formar novos miotubos, e os mionúcleos transplantados, geneticamente normais, devem direcionar à produção de proteína distrofina funcional.

A fim de alcançar relevância clínica no caso das distrofias, populações candidatas de células tronco devem ser facilmente obtidas, serem capazes de gerar músculo e, quando transplantadas devem integrar-se na musculatura, levando à correção do fenótipo distrófico. Por isso, torna-se necessária a identificação de novas fontes de células precursoras miogênicas, uma vez que a maioria identificada até agora, têm se mostrado com efeito terapêutico limitado. Além disso, a definição de vias de injeção destas células também é muito importante, pois elas precisam atingir toda a musculatura esquelética do indivíduo. 
Baseados nos diferentes trabalhos que investigam o potencial das células tronco em experimentos de co-cultura e em transplante de animais, torna-se imprescindível determinar a linhagem de células tronco mais viável capaz de promover a reparação ou a substituição perfeita do tecido em estudo.

\section{- Experimentos com células tronco mesenquimais}

A identificação da existência na medula óssea de uma população de células tronco mesenquimais circulantes com potencial miogênico ocorreu no final dos anos 1960 (FRIEDESTEIN et al., 1966). Baseados nesse achado, em 1998, FERRARI et al. confirmaram que essas células poderiam participar do reparo muscular após lesão, entretanto o nível de incorporação delas no músculo seria muito baixo. A partir de então, estudos envolvendo o transplante de células derivadas de medula óssea conduzidas no camundongo $m d x$ mostraram a restauração parcial da expressão de distrofina (GUSSONI $e t$ al., 1999). Essas células persistiam por longos períodos de tempo no músculo e mantinham a expressão da proteína, no entanto a quantidade de músculo gerado após o seu transplante não compreendeu um montante terapeuticamente relevante correspondendo a apenas $0,5 \%$ da regeneração originada de fibras exógenas (GUSSONI et al., 2002; FERRARI \& MAVILIO, 2002). Sendo assim, nenhum destes experimentos fornecem dados que comprovem realmente que as células transplantadas participam da correção fisiológica do fenótipo distrófico. No entanto, essas células tornaram-se potencialmente capazes de gerar tecido muscular e abriu-se uma nova frente de pesquisas para se identificar formas de sua utilização. 


\section{Experimentos in vitro}

O debate em torno da natureza pluripotentes das células MSC continua. Por isso, neste projeto, realizou-se uma investigação a respeito de sua capacidade de induzir miogênese in vitro, antes de elas serem utilizadas como fonte terapêutica no tratamento da DMD. Verificou-se que estas células eram capazes de se diferenciar espontaneamente em músculo em meio de cultura suplementado com Soro Fetal Bovino e constatou-se a ocorrência de fusão celular. Nesta fase, identificamos que as células mesenquimais de uma forma geral têm a capacidade de se fundirem sozinhas, sem estímulo de outros tipos celulares.

Também se testou alguns protocolos de diferenciação induzida. Primeiramente, tentamos reproduzir os resultados obtidos por LIN et al. (2006) que verificaram que, as células MSC de gordura suplementadas com hidrocortisona, passaram a expressar genes específicos musculares. Além desse teste, também verificamos a capacidade miogênica das células MSC quando cultivadas na presença de Interleucina-6 (IL-6), uma vez que o recrutamento e a fusão de células satélites são regulados por fatores de crescimento, dentre eles a IL-6. A sua síntese vai ser regulada por várias vias de transdução de sinal, inclusive do p38, que é provavelmente uma das principais vias de sinalização intracelular reguladora do desenvolvimento miogênico, principalmente pela ativação de células satélites depois de uma injúria ou no caso de doenças musculares degenerativas (BAEZA-RAJA \& MUÑOZCÁNOVES, 2004; KEREN et al., 2006). BAEZA-RAJA \& MUÑOZ-CÁNOVES (2004) demonstraram que a adição desta citocina ao meio de cultura celular, aumenta a expressão de genes específicos musculares. Os nossos resultados foram positivos, na medida em que as células $\mathrm{C} 2 \mathrm{C} 12$ (mioblastos), usadas como controle positivo, expressam 
constitutivamente os fatores musculares e as células MSC passaram a expressar distrofina depois de submetidas ao processo de diferenciação.

Por outro lado, uma vez que trabalhos recentes (BALL et al., 2003; LEE et al., 2005; GONÇALES et al., 2006) já haviam mostrado que o contato com outras células em diferenciação é um determinante crítico no comprometimento miogênico de células tronco mesenquimais, realizou-se o seu co-cultivo com mioblastos de camundongos $m d x$. Apesar da ocorrência de fusão celular, não se pode comprovar a formação de miotubos híbridos, uma vez que não se conseguiu visualizar a fluorescência verde das células eGFP após a fusão. Além disso, como a fusão celular é uma característica intrínseca das células tronco, a observação deste fenômeno não pode ser utilizada como uma evidência de indução à miogênese através de fatores musculares liberados pelos mioblastos do músculo afetado.

Entretanto, através da metodologia de Western Blotting, foi detectada a presença de uma banda discreta de proteína distrofina somente no extrato de células mesenquimais indiferenciadas, o que confirma que as células MSC podem, em alguns momentos e sob o estímulo de proliferação, se diferenciar espontaneamente em músculo, sem necessitar de outros estímulos. O que explicaria esse resultado é o fato de que as células MSC são na verdade formadas por uma população mais heterogênea de células, com capacidades de diferenciação específicas (DORSHKIND, 1990; GRONTHOS \& SIMMONS, 1995; PITTENGER et al., 1999). Neste caso, a população em análise pode eventualmente estar mais enriquecida com linhagens com o potencial miogênico. 


\section{Experimentos in vivo}

Apesar de se demonstrar que as células tronco, quando induzidas in vitro, expressam marcadores de diferenciação miogênica, é importante confirmar que elas podem se diferenciar em células musculares com função especializada suficiente para serem utilizadas em terapias, principalmente no caso do músculo distrófico. Assim sendo, depois de realizados os experimentos in vitro e com a certeza do potencial miogênico das células MSC de medula óssea, realizou-se os experimentos de injeções em camundongos $m d x$, com a finalidade de verificar se o ambiente muscular in vivo, através da geração de estímulos próprios ligados ao processo de lesão muscular, podem direcionar a capacidade dessas células de gerar músculo.

\section{a. Injeção intramuscular}

Nosso primeiro objetivo foi verificar se células MSC, depois de implantadas localmente em músculo esquelético de camundongos $m d x$, se fundiriam entre si ou com as fibras musculares do camundongo receptor, passando a expressar distrofina depois de 3 semanas, reproduzindo os experimentos descritos por DEZAWA et al. (2005) e DE BARI et al. (2003).

Entretanto, não se verificou nenhum sinal de regeneração muscular através da coloração de hematoxilina-eosina, ou ainda algum evento que chamasse atenção para o aparecimento da proteína distrofina, através da reação de imunofluorescência. Em contrapartida, por esta técnica, observou-se um padrão de fundo com marcação intersticial entre as fibras musculares nos músculos do camundongo $m d x$ controle negativo, bem como nos músculos injetados, além da autofluorescência inerente do músculo estriado e do tecido 
conjuntivo associado, o que dificultou a interpretação dos resultados. Por isso, o uso de anticorpos adequados tornou-se de extrema importância, uma vez que os anticorpos rotineiramente utilizados são monoclonais desenvolvidos em camundongos. Isto dificulta a sua utilização, no caso do nosso experimento, devido ao possível background provocado pelo anticorpo secundário. Então, procurou-se um anticorpo que fosse desenvolvido em outros animais para que possibilitassem uma análise mais confiável. Portanto, os possíveis eventos positivos têm que ser bem diferenciados de eventos falso-positivos, o que tornou este um ponto bem crítico na análise dos nossos resultados. A análise de distrofina por Western blotting, entretanto, não confirmou a presença de quantidade significante da proteína nos músculos injetados.

Uma vez que não se tinha conseguido identificar a expressão de distrofina no experimento de longa duração, realizou-se um ensaio mais rápido de 1 semana, a fim de verificar se a ausência desta proteína ocorria porque as células eGFP não permaneciam nos músculos injetados ou porque elas não teriam se diferenciado em músculo. Assim, começou a se rastrear diretamente as células injetadas eGFP através da avaliação dos cortes histológicos e por imunfluorescência e Western blotting para a proteína GFP, mas não se obteve sucesso na identificação dessas células. Entretanto, em outro experimento de injeção de 2 e 3 dias, se conseguiu rastrear o gene eGFP por PCR no músculo desses camundongos o que mostrou que as células estariam presentes até pelo menos 3 dias depois de implantadas. Após este tempo, as células transplantadas possivelmente são eliminadas, uma vez que não se conseguiu localizar o gene eGFP nos experimentos de longa duração. Este foi um indício mais concreto de que as células MSC injetadas não estariam gerando resultado terapêutico positivo porque elas estariam sendo eliminadas depois de poucos dias 
de implantadas e por isso, não ficariam em contato com o músculo degenerado por tempo suficiente para se fundir e expressar a proteína distrofina exógena.

Mesmo assim, uma vez que DI ROCCO et al. (2006) verificaram que células mesenquimais de tecido adiposo eram mais comprometidas com a diferenciação muscular em suas passagens iniciais em cultura, realizou-se novamente um experimento de longa duração, utilizando-se as células neste estágio de cultura. Entretanto, os resultados continuaram os mesmos.

Este resultado negativo também foi publicado por BALSAM et al. (2004) para a restauração do miocárdio, em que as células não foram localizadas após 30 dias de injetadas.

\section{b. Injeção sistêmica}

Concomitantemente aos experimentos de injeções intramusculares, iniciou-se a implantação de células MSC eGFP via sistêmica, nas mesmas condições até então utilizadas, uma vez que o grande desafio para se obter sucesso em terapias com células tronco para distrofias musculares está ligado à capacidade das células transplantadas de se disseminarem para todos os músculos afetados. O direcionamento das células MSC depois de implantes sistêmicos já foi relatado por vários grupos, que demonstraram que elas possuem grande capacidade migratória, sendo capazes de migrar para sítios de lesões em animais (FERRARI et al., 1998; SAMPAOLESI et al., 2006) e formar infiltrados com morfologia de miofibroblatos nos tecidos musculares de camundongos com tecido danificado (ANJOS-AFONSO et al., 2004). Como descrito (POUNTOS \& GIANNOUDIS, 2005; BOUCHENTOUF et al. 2006), as células MSC depois de injetadas são atraídas ao local da lesão, uma vez que o tecido lesionado passaria a expressar receptores específicos, 
facilitando o tráfego, a aderência e a infiltração de células MSC no local a ser reparado. Em nosso experimento, no entanto, a análise da proteína distrofina por imunofluorescência e Western blotting, assim como o rastreamento do gene eGFP, também mostraram resultados negativos, provando que possivelmente, as células injetadas não estariam sendo direcionadas para o músculo distrófico.

\section{c. Imunossupressão e incompatibilidade imunológica}

Apesar de relatos bibliográficas sugerindo que as células MSC não geram resposta imune, uma vez que foram descritas como não imunogênicas (CHAMBERLAIN et al., 2007), as células utilizadas em nossos experimentos estavam sendo sistematicamente rejeitadas e eliminadas pelos camundongos receptores. Por isso, iniciamos ensaios de implantação de células em camundongos $m d x$ imunossuprimidos. Mesmo assim, após 15 dias, não se conseguia localizar as células injetadas.

Por outro lado, poderia estar havendo incompatibilidade imunológica entre as diferentes linhagens de camundongos utilizados, uma vez que os camundongos eGFP são da linhagem $F V B$ e os camundongos $m d x$ são da linhagem C57black6. Além disso, também, poderia se esperar que o processo distrófico ativo, que envolve um mecanismo de degeneração e regeneração com intensa interferência de fatores inflamatórios e estímulo para a proliferação de tecido conjuntivo, de alguma forma, interferisse na manutenção das células injetadas nos músculos dos camundongos $m d x$. Sendo assim, realizou-se um experimento com a implantação de MSC eGFP em músculo gastrocnêmio de camundongos FVB selvagens (não expressando a proteína GFP) e de camundongos C57black6. Entretanto, continuamos a observar a presença das células no músculo dos camundongos 
injetados somente após 2 dias, o que descarta a hipótese de rejeição das células devido a diferença de linhagens e de interferência da degeneração.

\section{d. Incompatibilidade à proteína GFP}

Outro ponto importante que merece ser mais bem investigado quando se pensa numa suposta eliminação das células depois de injetadas é a possível reação imune provocada pelo uso da proteína fluorescente verde (GFP). Este polipeptídio é proveniente da medusa Aequorea victoria, e é bioluminescente sob iluminação adequada, sendo completamente estável, suportando inúmeros tratamentos e processos químicos (OKABE et al., 1997). Por esta razão, os camundongos transgênicos eGFP transformaram-se em uma ferramenta muito útil em experiências de transplante de células, uma vez que quase todas as suas células emitem fluorescência e permitem a visualização e monitoramento in vivo por um processo não invasivo através da observação macroscópica, microscópica ou por citometria de fluxo (LEE et al., 2005; GONÇALES et al., 2006).

Apesar de seu grande valor para a pesquisa, a ampliação do uso desta ferramenta molecular tem mostrado alguns efeitos citotóxicos, envolvendo a apoptose de células transfectadas, em diversos trabalhos in vitro. LIU et al. (1999) mostraram pela primeira vez que ela podia induzir a apoptose, mas não elucidaram de que forma isto poderia ocorrer. Sugeriram, também, que essa talvez fosse uma possível razão para a dificuldade de estabelecer linhagens celulares estáveis expressando GFP. Atualmente, já se sabe que peptídeos derivados da proteína GFP podem induzir a resposta imune contra células (STRIPECKE et al., 1999; RE et al., 2004). Estes resultados indicam que a resposta imune contra o eGFP pode interferir com a sua aplicabilidade em estratégias terapêuticas. 
Uma explicação alternativa para a dificuldade de visualizar as células eGFP nos músculos injetados, poderia ser o fato da proteína GFP ser extremamente solúvel. Neste caso, ela pode ter se difundido rapidamente na água ou no citoplasma da célula como descrito por BRAZELTON \& BLAU em 2005, ou simplesmente ser perdida em consequiência do comprometimento da integridade da membrana pela criopreservação ou secção.

Por outro lado, estudos in vivo (STRIPECKE et al., 1999; GAMBOTTO et al., 2000; ROSENZWEIG et al., 2001; BUBNIC et al., 2005) verificaram a imunogenicidade de células hematopoiéticas marcadas com GFP após o transplante em animais imunocompetentes. Observaram que essas células eram perdidas após a sua infusão. Mais efeitos deletérios desta proteína também foram comprovados por outros pesquisadores. Já foi descrito que a co-expressão dose-dependente de eGFP e $\beta$-galactosidase no citoplasma de neurônios resultaram em retardo no crescimento e morte prematura. (KRESTEL et al., 2004) e AGBULUT et al. (2007) identificaram o mecanismo que associa a expressão de eGFP a disfunções contráteis e testaram a hipótese de que o eGFP poderia inibir a interação actina-miosina no músculo. Isso aconteceria porque o eGFP compete com a actina pelo sítio de ligação à miosina.

Estudos complementares de imunocompatibilidade estão sendo iniciados para elucidar as questões levantadas. 


\section{- Experimentos com células tronco embrionárias}

Ensaios terapêuticos com células ES não têm tido um impacto significativo no tratamento das distrofias musculares. Os primeiros trabalhos que investigaram os padrões de expressão gênica, as propriedades funcionais, e a morfologia das células ES murinas mostraram que elas seriam capazes de gerar pequenas quantidades de músculo esquelético (ROHWEDEL et al., 1994). No entanto, desde então, houve poucos avanços na tentativa de se melhorar a eficiência deste processo.

\section{Experimentos in vitro}

Da mesma forma que se testou a capacidades das células MSC em se diferenciarem em mioblastos in vitro, verificou-se a capacidade de diferenciação espontânea por contato das células ES. Entretanto, não se conseguiu identificar quantidade significativa de distrofina. Fizemos isso, baseados em REUBINOFF et al. que em 2000 verificaram que as células ES sofriam diferenciação espontânea, ao observar que alguns feixes de células musculares sob condições normais de cultura mantendo uma alta densidade de células por períodos alongados.

Então, submetemos as células ES ao processo de diferenciação em Corpos Embrióides e à co-cultura com mioblastos distróficos. In vitro, as células tronco embrionárias (ES) podem se propagar indefinidamente em um estado indiferenciado em presença de Fator Inibitório de Leucemia (LIF) e no topo da camada de FEEDER, retendo sua capacidade de se diferenciarem em diferentes fenótipos quando induzidas com sinais apropriados (DOSS et al., 2004). Para se diferenciar as ES em diversos fenótipos, essas células têm que ser cultivadas em agregados multicelulares denominados Corpos 
Embrióides (EB), dando origem a células das 3 camadas germinativas do desenvolvimento embrionário. É relativamente fácil gerar mioblastos a partir das células tronco embrionárias. Consegue-se isso tratando os Corpos Embrióides com 1\% de DMSO pelos primeiros 5 dias, levando a formação de clusters de células ES em diferenciação (WOBUS et al., 2002). Sendo assim elas passaram a expressar marcadores musculares, confirmando que, apesar dessas células não estarem expressando distrofina em grande quantidade, têm a capacidade de se diferenciar em músculo.

\section{Experimentos in vivo}

\section{a. Injeção de células ES}

Recentemente, foi realizado um estudo em que se verificou que depois de 2 semanas de implantação de co-cultura de EB com mioblastos $m d x$, em músculo de camundongos distróficos, aparecia expressão de distrofina exógena (BHAGAVATI \& XU, 2005). Esse experimento representou um grande avanço na utilização de células ES no tratamento da DMD. Permanecem, entretanto, algumas questões quanto ao mecanismo pelo qual essas células podem contribuir para o processo de regeneração muscular. Por isso, neste trabalho, também se pretendeu investigar o potencial miogênico destas células quando injetadas em camundongos $m d x$ sem a interferência de outro tipo celular.

A capacidade imunogênica das células ES ainda não está bem definida. Por isso, nesse trabalho, optou-se pela injeção destas células em camundongos $m d x$ imunossuprimidos e não imunossuprimidos. Somente em 2 camundongos imunossuprimidos, observou-se que as patas injetadas apresentavam um grande aumento da massa. A análise histopatológica mostrou muitos focos de degeneração intensa e infiltração 
de diversos tipos de células imaturas. Isso sugere que as células injetadas podem ter se multiplicado e sido incorporadas ao músculo do camundongo provocando uma reação inflamatória muito intensa e sua possível diferenciação em outros tipos celulares.

Como as células injetadas estavam coradas de vermelho, foi possível visualizá-las e identificá-las no músculo injetado de alguns camundongos imunossuprimidos. O mesmo evento não foi observado em camundongos não imunossuprimidos, onde somente se verificou a presença das células nos animais injetados e sacrificados após 2 dias. Isso sugere que as células só conseguiram se manter no músculo dos camundongos imunossuprimidos ou ainda, que através de divisões celulares intensas, o corante vermelho estaria se diluindo. Nos camundongos injetados sistemicamente só se observou presença de marcação vermelha na região da cauda por onde essas células foram introduzidas. Estes resultados sugerem que as células injetadas pela veia caudal ficaram restritas ao local da injeção, não conseguindo se distribuir e se disseminar para o músculo lesado ou para os outros tecidos avaliados.

A análise do músculo injetado do camundongo $M d x 37$ mostrou a presença de uma formação, parecida com novas fibras musculares, positivas para distrofina, no meio da região com predomínio de infiltração. Para verificar se realmente estava ocorrendo a formação de novas fibras musculares, reagimos lâminas deste tecido com o anticorpo antimiosina fetal. Os músculos esqueléticos de mamíferos co-expressam diferentes tipos de miosina. Esta molécula é formada por duas cadeias pesadas de miosina e dois pares regulatórios de cadeia leve. A miosina de cadeia pesada (MHC) é uma das principais proteínas sarcoméricas responsáveis pela diferenciação do mioblasto e tem sido usada como um marcador de diferenciação muscular, que junto com outras proteínas estruturais, formam as primeiras estruturas do sarcômero (FULTON \& ALFTINE, 1997; RAFAEL \& 
BROWN, 2000; MULLER et al., 2001). No músculo esquelético de mamíferos são encontradas sete isoformas de MHC, quatro dessas no músculo esquelético adulto e uma adicional predominando no músculo cardíaco (WEISS \& LEINWAND, 1996). O camundongo $m d x$ apresenta intensa mionecrose e regeneração evidenciada pela freqüente expressão de fibras com a isoforma da cadeia pesada da miosina fetal e por fibras com nucleação central (BLAKE et al., 2002). Sendo assim, se houvesse a formação de novas fibras, esse anticorpo seria um bom marcador. Entretanto, não observamos nenhum sinal de marcação positiva, somente um padrão de reação característico de cortes histológicos de camundongos $m d x$ não injetados.

Por outro lado, através de PCR com marcadores de microssatélites próprios de cada linhagem de camundongo pôde-se verificar a presença das células tronco somente no músculo injetado do camundongo $M d x$ 37, não havendo a detecção das células no camundongo $M d x$ 38, sugerindo uma provável eliminação com o passar do tempo.

Para determinar a sensibilidade de detecção de nosso teste de DNA, foi elaborada uma curva padrão com concentrações conhecidas de DNA das duas linhagens diferentes de camundongos. Neste teste, o limite mínimo de identificação do DNA da linhagem das células ES foi de 30\%. O número de células ES presentes no camundongo $M d x 37$ injetado foi muito próximo a este limite de detecção de 30\%. Nos outros animais injetados e imunossuprimidos, é possível que a resolução da metodologia não tenha permitido a sua visualização. Isto não indica necessariamente a ausência total de células no local injetado mas sugere que um número grande delas foi eliminado, e que a sua concentração é certamente inferior a $30 \%$. 
Corroborando com os nossos resultados, KOFIDIS et al. (2005), verificaram que as células ES morrem rapidamente após a injeção intramiocárdica (75\% das células mortas após 48 horas).

\section{b. Injeção de células $\mathrm{EB}$}

Também se testou a implantação local e sistêmica de células extraídas de Corpos Embrióides, em camundongos $m d x$ imunossuprimidos. A intenção foi verificar se um estímulo de diferenciação em músculo, ainda com as células em cultura, melhoraria o seu potencial de repovoar com células musculares distrofina positivas a área degenerada. Diferentemente dos outros experimentos, observou-se a presença de algumas fibras musculares positivas para a proteína distrofina. Entretanto, essa quantidade de fibras distrofina positivas também pode ser encontrada em camundongos $m d x$ não injetados, devido às fibras revertentes freqüentemente observadas em músculos distróficos (HOFFMAN et al.,1987; 1990). Então, não se pode garantir que essa marcação seja relativa a uma expressão de proteína suficiente, uma vez que não apareceu distrofina na análise por Western blotting. No entanto, também não se conseguiu identificar essas células por PCR, o que pode indicar que embora elas tenham permanecido no músculo em quantidade inferior a $30 \%$, se incorporadas, podem ter se fundido e começado a expressar distrofina.

\section{c. Imunogenicidade das células ES e de células EB}

A literatura indica que tem havido um conflito quanto ao verdadeiro potencial imunogênico das células ES. DRUKKER et al. (2002) e BONDE \& ZAVAZAVA (2006) caracterizam o perfil de expressão de moléculas responsáveis pela resposta imunológica das células ES, EB e teratomas. Foi observado que as células ES humanas e murinas 
expressavam níveis baixos de moléculas de HLA classe I, além de que elas eram destruídas muito ineficientemente por células NK in vitro. Esse nível aumentava quando as células foram induzidas a diferenciar espontaneamente em EB. Esses dados revelam que as células embrionárias indiferenciadas não seriam imunogênicas. Por isso, em alguns casos, não utilizamos a imunossupressão. Inclusive, uma revisão de 2007 descreve os mecanismos utilizados pelas células ES para evitar sua destruição pela resposta imunológica do organismo receptor (UTERMÖHLEN \& KRÖNKE, 2007). Esse grupo demonstra que as células ES desenvolveram mecanismos para proteger-se das células efetoras citotóxicas.

Por outro lado, outros trabalhos (REUBINOFF et al., 2000; BRADLEY et al., 2002; ANDREWS et al., 2005; MIMEAULT et al., 2007) mostram que o transplante de células ES indiferenciada em camundongos SCID (camundongo imunodeficientes) levava à formação desorganizada de tumores conhecidos como teratomas, que continham tecidos derivados das três camadas germinais embrionárias, com as propriedades das células injetadas, depois de cerca de cinco semanas de inoculação.

Outro caso interessante foi verificado em transplantes destinados a regeneração cerebral (ERDÖ et al., 2003), em que células ES murinas indiferenciadas foram transplantadas no cérebro de ratos no hemisfério oposto à lesão isquêmica e migraram para os tecidos danificados, diferenciando-se em neurônios. Com as mesmas células, foi realizado o transplante no cérebro de camundongos, em que elas não migraram, e tornaramse altamente malignas, formando teratocarcinomas. Os autores demonstraram desta forma, um resultado inverso até então negado após xenoenxertos e transplante homólogo. 


\section{- Considerações finais}

Independentemente da sua origem, as diversas populações de células tronco têm que ser mais bem estudadas antes da sua utilização terapêutica. A sua sobrevivência e a subseqüente migração do local da injeção até o local danificado continua sendo um grande obstáculo para muitas das populações de células descritas. Também se torna preocupante a possível resposta imunológica gerada a partir da introdução de um tipo de célula estranha ao organismo receptor, ou no caso da DMD, à uma proteína estranha. Por isso, existe uma clara necessidade de estabelecer estratégias para se evitar a rejeição das células transplantadas e verificar o quanto é seguro a utilização das células tronco em terapias, em termos da sua tumorigenicidade e potencial risco de transmissão de infecções (THOMSON et al., 1998; WU et al., 2007).

Para se escolher qual tipo de célula utilizar, deve-se aprender a como se lidar com essas questões. Uma melhor compreensão do que ocorre com essas células in vivo e as consequiências para o organismo receptor são de extrema importância para o sucesso do transplante de células tronco. 


\section{Experimentos com células tronco mesenquimais}

- As células tronco mesenquimais de medula óssea têm a capacidade, em alguns momentos e sob o estímulo de proliferação, de se fundirem sozinhas in vitro e se diferenciarem espontaneamente em músculo sem estímulo de outros tipos celulares e sem a necessidade de indução à miogênese por fatores musculares liberados pelos mioblastos do músculo afetado.

- As células tronco mesenquimais eGFP, quando injetadas localmente em camundongos $m d x$, só foram detectadas no músculo injetado, no máximo, depois de 3 dias, sugerindo uma possível eliminação das mesmas. Desta forma, elas não ficariam em contato com o músculo degenerado por tempo suficiente para se fundirem e começarem a expressar proteína distrofina, não gerando resultado terapêutico positivo.

- Nos experimentos de injeção sistêmica, as células MSC também não foram direcionadas corretamente para o músculo degradado, sugerindo que o processo distrófico por si só não seria suficiente para poder atrair essas células ou que elas, mesmo sendo injetadas por outra via também estariam sendo eliminadas.

- Através dos experimentos de imunossupressão e de injeções em diferentes linhagens, também se descartou a hipótese de rejeição das células devido à diferença de linhagens e de interferência da degeneração, o que pode indicar que a proteína GFP estaria sendo responsável pela morte prematura dessas células in vivo. 


\section{Experimentos com células tronco embrionárias}

- As células tronco embrionárias e os Corpos Embrióides têm a capacidade de se diferenciar em músculo, apesar dessas células não estarem expressando distrofina em grande quantidade in vitro.

- As células ES, quando injetadas em músculo de camundongos $m d x$ imunossuprimidos, têm a capacidade de gerar reação inflamatória muito intensa, provocando o aparecimento de muitos focos de degeneração e uma possível diferenciação em outros tipos celulares. Entretanto, o mesmo evento não pode ser observado em camundongos não imunossuprimidos, sugerindo que as células estariam sendo eliminadas após 2 dias.

- $\quad$ Nos camundongos injetados sistemicamente, encontrou-se células ES na região da cauda por onde essas células foram introduzidas, o que pode significar que essas células fiquem restritas ao local da injeção, não conseguindo se distribuir e se disseminar para o músculo lesado.

- $\quad$ Somente foi possível identificar as células injetadas quando havia 30\% ou mais das mesmas ainda presentes na amostra. Abaixo deste nível, a resolução da metodologia aplicada não permitiu a sua visualização, não indicando necessariamente a ausência total de células no local injetado e sim que um maior número delas foi eliminado. 
- Com a implantação local e sistêmica de células de Corpos Embrióides em camundongos $m d x$ imunossuprimidos observou-se a presença de algumas fibras musculares positivas para a proteína distrofina. Mesmo assim, não se pode garantir que essa marcação seja relativa a uma expressão de proteína suficiente, uma vez que essa marcação pode ser relativa a fibras revertentes freqüentemente observadas em músculos distróficos, uma vez que não se observou a presença das células por PCR o que pode indicar que elas permaneceram em uma quantidade inferior a $30 \%$.

- $\quad$ Portanto, no nosso estudo não foi possível se confirmar a fusão das células injetadas com o músculo do camundongo distrófico, nem identificar quantidade significativa de proteínas musculares, inclusive da distrofina, nos músculos injetados e nos experimentos do co-cultura através das técnicas utilizadas. 
7. REFERÊNCIAS BIBLIOGRÁFICAS 
AGBUlut, O., HUET, A., NIEDERLÄNDER, N., PUCEAT, M., MENASCHÉ, P., COIRAULT, C. (2007). Green fluorescent protein impairs actin-myosin interactions by binding to the actin-binding site of myosin. J. Biol. Chemistry, 282 (14): 10465-10471.

ANDREWS, P. W., MATIN, M. M., BAHRAMI, A. R, DAMJANOV, I., GOKHALE, P., DRAPER, J. S. (2005). Embryonic stem (ES) cells and embryonal carcinoma (EC) cells: opposite sides of the same coin. Biochem. Soc. Trans., 33: 1526-1530.

ANJOS-AFONSO, F., SIAPATI, E. K., BONNET, D. (2004). In vivo contribution of murine mesenchymal stem cells into multiple cell-types under minimal damage conditions. J Cell Sci, 117 (23): 5655-5664.

BAEZA-RAJA, B. \& MUÑOZ-CÁNOVES, P. (2004). P38 MAPK-induced nuclear factor$\kappa \mathrm{B}$ activity is required for skeletal muscle differentiation: Role of interleukin-6. Mol. Bio. Cell, 15: 2013-2026.

BAKSH, D., SONG, L., TUAN, R. S. (2004). Adult mesenchymal stem cells: characterization, differentiation, and application in cell and gene therapy. J Cell Mol Med, 8: 301-316.

BAlL, S. G. B., SHUTtleWORTH, A. C., KIELTY, A. M. (2003). Direct cell contact influences bone marrow mesenchymal stem cell fate. IJBCB, 36: 714-727.

BALSAM, L. B., WAGERS, A. J., CHRISTENSEN, J. L., WEISSMAN, I. L., ROBBINS, R. C. (2004). Haematopoietic stem cells adopt mature haematopoietic fates in ischaemic myocardium. Nature, 428 (6983): 668-673.

BARBERI, T., BRADBURY, M., DINCER, Z., PANAGIOTAKOS, G., D SOCCI, N., STUDER, L. (2007). Derivation of engraftable skeletal myoblasts from human embryonic stem cells. Nature Med., 13 (5): 642-648. 
BHAGAVATI, S. \& XU, W. (2005). Generation of skeletal muscle from transplanted embryonic stem cells in dystrophic mice, Biochem. Biophys. Res. Commun., 333: 644-649.

BITTNER, R. E., SCHÖFER, C., WEIPOLTSHAMMER, K., IVANOVA, S., STREUBEL, B., HAUSER, E., FREILINGER, M., HÖGER, H., ELBE-BÜRGER, A., WACHTLER, F. (1999). Recruitment of bone-marrow-derived cells by skeletal and cardiac muscle in adult dystrophic mdx mice. Anat Embryol, 199:391-396.

BLAKE, D. J., WEIR, A., NEWER, S. E., DAVIES, K. E. (2002). Function and genetics of distrophin and dystrophin-related proteins in muscle. Physiol Rev, 82: 291-329.

BONDE, S. \& ZAVAZAVA, N. (2006). Immunogenicity and Engraftment of Mouse Embryonic Stem Cells in Allogeneic Recipients. Stem Cells, 24: 2192-2201.

BOUChENTOUF, M., BENABDAllah, B. F., MILlS, P., TREMBLAY, J. P. (2006). Exercise improves the success of myoblast transplantation in mdx mice. Neurom Disor, 16: $518-529$.

BRADley, J. A., BOLTON, E. M., PEDERSEN, R. A. (2002). Stem cell medicine encounters the immune system. Nature reviews, 2: $859-871$.

BRAZELTON, T. R. \& BLAU, H. M. (2005). Optimizing techniques for tracking transplanted stem cells in vivo. Stem Cells, 23: 1251-1265.

BUBNIC, S. J., NAGY, A., KEATING, A. (2005). Donor hematopoietic cells from transgenic mice that express GFP are immunogenic in immunocompetent recipients. Hematology, 10(4):289-295.

BULFIELD, G., SILLER, W. G., WIGHT, P. A., MOORE, K. J. (1984). X chromosomelinked muscular dystrophy $(m d x)$ in the mouse. Proc Natl Acad Sci USA, 81: 11891192. 
BUSHBY, K. M. D. \& BECKMANN, J. S. (1995). Diagnostic criteria for the limb-girdle muscular dystrophies: Report of the ENMC workshop on limb-girdle muscular dystrophies. Neuromuscul. Disord., 5: 71-74.

CHAKKALAKAL, J. V., THOMPSON, J., PARKS, R. J., JASMIN, B. J. (2005). Molecular, cellular and pharmacological therapies for Duchenne/Becher muscular dystrophies. The FASEB Journal, 19: 880-891.

CHAMBERLAIN, G., FOX, J., ASHTON, B., MIDDLETON, J. (2007). Mesenchymal stem cells: their phenotype, differentiation capacity, immunological features and potential for homing. Stem Cells, doi: 10.1634/stem cells.2007-0197.

CHARGÉ, S. B. P. \& RUDNICKI, M. A. (2004). Cellular and molecular regulation of muscle regeneration. Physiol Rev, 84: 209-238.

DANKO, I., CHAMPMAN, V., WOLFF, J. A. (1992). The frequency of revertants in mdx mouse genetic models for Duchenne muscular dystrophy. Pediatr Res, 32: 128-131.

DE BARI, C., DELl'ACCIO, F., VANDENAEELE, F., VERMEESCH, J. R., RAYMACKERS, J. M., LUYTEN, F. P. (2003). Skeletal muscle repair by adult human mesenchymal stem cells from synovial menbrane. J Cell Biol, 160: 909-918.

DEANS, R. J. \& MOSELEY, A. B. (2000). Mesenchymal stem cells: Biology and potential clinical uses. Exper Hemat, 28: 875-884.

DEZAWA, M., ISHIKAWA, H., ITOKAZU, Y., YOSHIHARA, T., HOSHINO, M., TAKEDA, S., IDE, C., NABESHIMA, Y. (2005). Bone marrow stromal cells generate muscle and repair muscle degeneration. Science, 309: 314-317. 
DI ROCCO, G., IACHININOTO, M. G., TRITARELli, A., STRAINO, S., ZACHEO, A., GERMANI, A., CREA, F., CAPOGROSSI, M. C. (2006). Myogenic potential of adipose-tissue-derived cells. J. Cell Sci., 119 (14): 2945-2952.

DORSHKIND, K. (1990). Regulation of hemopoiesis by bone marrow stromal cells and their products. Annu Rev Immunol, 8:111-137.

DOSS, M. X., KOEHLER, C. I., GISSEL, C., HESCHELER, J., SACHINIDIS, A. (2004). Embryonic stem cells: a promising tool for cell replacement therapy. J Cell Mol Med, 8: $465-473$.

DRUKKER, M., KATZ, G., URBACH, A., SCHULDINER, M., MARKEL, G., ITSKOVITZ-ELDOR, J., REUBINOFF, B., MANDELBOIM, O., BENVENISTY, N. (2002). Characterization of the expression of MHC proteins in human embryonic stem cells. Proc Natl Acad Sci USA, 99: 9864 - 9869.

ERDÖ F., BUHRLE, C., BLUNK, J., HOEHN, M., XIA, Y., FLEISCHMANN, B., FÖCKING, M., KUSTERMANN, E., KOLOSSOV, E., HESCHELER, J., HOSSMANN, K. A., TRAPP, T. (2003). Host-dependent tumorigenesis of embryonic stem cell transplantation in experimental stroke. Journal of Cerebral Blood Flow \& Metabolism, 23 (7): 780-785.

ERVASTI, J. M. \& CAMPBELL, K. P. (1991). Membrane organization of the dystrophinglycoprotein complex. Cell., 66: 1121-1131.

FERRARI, G., CUSELlA-DE ANGElis, G., COLETTA, M., PAOLUCCI, E., STORNAIUOLO, A., COSSU, G., MAVILIO, F. (1998). Muscle regeneration by bonemarrow-derived myogenic progenitors. Science, 279:1528-1530. 
FERRARI, G., STORNAIUOLO, A., MAVILIO, F. (2001). Bone marrow transplantation: Failure to correct murine muscular dystrophy. Nature, 411: 1014-1015.

FERRARI, G. \& MAVILIO, F. (2002). Myogenic stem cells from the bone marrow: a therapeutic alternative for muscular dystrophy? Neuromuscul. Disord. 12 (Suppl 1): S7-S10.

FISCHBACH, G. D. \& FISCHBACH, R. L. (2004). Stem cells: science, policy and ethics. J Clin Invest, 114: 1364-1370.

FRANCKE, U., OCHS, H. D., DE MARTINVILLE, B., GIACALONE, J., LINDGREN, V., DISTECHE, C., PAGON, R. A., HOFKER, M. H., VAN OMMEN, G. J. B., PEARSON, P. L., WEDGWOOD, R. J. (1985). Minor Xp21 chromosome deletion in a male associated with expression of Duchenne musculary dystrophy, chronic granulomatous disease, retinitis pigmentosa, and McLeod syndrome. Am. J. Hum. Genet., 37: 250-267.

FRIEDENSTEIN, A. J., PIATETZKY-SHAPIRO, I. I., PETRAKOVA, K. V. (1966). Osteogenesis in transplants of bone marrow cells. J. Embryol. Exp. Morphol., 16: 381-390.

FRIEDENSTEIN, A. J., GORSKAJA, J. F., KULAGINA, N. N. (1976). Fibroblast precursors in normal and irradiated mouse hematopoietic organs. Exp Hematol, 4: 267-274.

FULTON, A. B. \& ALFTINE, C. (1997). Organization of protein and mRNA for titin and other myofibril components during myofibrillogenesis in cultured chicken skeletal muscle. Cell Struct Funct, 22(1): 51-58. 
GAMBotto, A., DWORACKI, G., CICINNATI, V., KENNISTON, T., STEITZ, J., TÜTING, T., ROBBINS, P. D., DELEO, A. B. (2000). Immunogenicity of enhanced green fluorescent protein (EGFP) in BALB/c mice: identification of an $\mathrm{H} 2-\mathrm{Kd}$-restricted CTL epitope. Gene Ther., 7 (23): 2036-2040.

GARDNER-MEDWIN, D. (1980). Clinical features and classification of the muscular dystrophies. Br. Med. Bull., 36 (2): 109-115.

GOETSCH, S. C., HAWKE, T. J., GALLARDO, T. D., RICHARDSON, J. A., GARRY, D. J. (2003). Transcriptional profiling and regulation of the extracellular matrix during muscle regeneration. Physiol Genomics, 14: 261-271.

GONÇALES, M. A. F. V., VRIES, A. A. F., HOLKERS, M., VAN DE WATERING, M. J. M., VELDE, I., NIEROP, G. P., VALERIO, D., KNÄ̈N-SHANZER, S. (2006). Human mesenchymal stem cells ectopically expressing full-length dystrophin can complement Duchenne muscular dystrophy myotubes by cell fusion. Hum Mol Gen, 15(2): 213-221.

GRONTHOS, S. \& SIMMONS, P. J. (1995). The growth factor requirements of Stro-1positive human stromal precursors under serum-deprived conditions in vitro. Blood, 85: 929-940.

GUSSONI, E., SONEOKA, Y., STRICKLAND, C. D., BUZNEY, E. A., KHAN, M. K., FLINT, A. F., KUNKEL, L. M., MULLIGAN, R. C. (1999). Dystrophin expression in the mdx mouse restored by stem cell transplantation. Nature, 401: 390-394. 
GUSSONI, E., BENNETT, R. R., MUSKIEWICZ, K. R., MEYERROSE, T., NOLTA, J. A., GILGOFF, I., STEIN, J., CHAN, Y. M., LIDOV, H. G., BÖNNEMANN, C. G., VON MOERS, A., MORRIS, G. E., DEN DUNNEN, J. T., CHAMBERLAIN, J. S., KUNKEL, L. M., WEINBERG, K. (2002). Long-term persistence of donor nuclei in a Duchenne muscular dystrophy patient receiving bone marrow transplantation. J. Clin. Invest., 110 (6): 807-814.

HAWKE, T. J. \& GARRY, D. J. (2001). Myogenic satellite cells: physiology to molecular biology. J Appl Physiol, 91: 534-551.

HOFFMAN, E. P., BROWN, R. H., KUNKEL, L. H. (1987). Dystrophin: the protein product of the Duchenne Muscular Dystrophy Locus. Cell., 51: 919-928.

HOFFMAN, E. P., MORGAN, J. E., WATKINS, S. C., PARTRIDGE, T. A. (1990). Somatic reversion/suppression of the mouse $\mathrm{mdx}$ phenotype in vivo. Journal of the Neurological Sciences, 99: 9-25.

HOFFMAN, E. P. \& DRESSMAN, D. (2001). Molecular pathophysiology and targetd therapeutics for muscular dystrophy. Pharmacol Sci, 22: 465-470.

KEREN, A., TAMIR, Y., BENGAL, E. (2006). The p38 MAPK signeling pathqay: A major regulator of skeletal muscle development. Mol. Cell. Endocrinology, 252: 224-230.

KOENIG, M., BEGGS, A. H., MOYER, M., SCHERPF, S., HEINDRICH, K., BETTECKEN, T., MENG, G., MULLER, C.R., LINDLOF, M., KAARIAINEN, H., et al. (1989). The molecular basis for Duchenne versus Becker muscular dystrophy: correlation of severity with type of deletion. Am J Hum Genet, 45: 498-506. 
KOFIDIS, T., BRUIN, J. L., TANAKA, M., ZWIERZCHONIEWSKA, M., WEISSMAN, I., FEDOSEYEVA, E., HAVERICH, A., ROBBINS, R. C. (2005). They are not stealthy in the heart: embryonic stem cells trigger cell infiltration, humoral and T-lymphocytebased host immune response. European Journal of Cardio-thoracic Surgery, 28: $461-466$.

KRAMPERA, M., PIZZOLO, G., APRILI, G., FRANCHINI, M. (2006). Mesenchymal stem cells for bone, cartilage, tendon and skeletal muscle repair. Bone, 39(4): 678-683.

KRESTEL, H. E., MIHAlJEVIC, A. L. A., HOFFMAN, D. A., SCHNEIDER, A. (2004). Neuronal co-expression of eGFP and beta-galactosidase in mice causes neuropathology and premature death. Neuro. Desease, 17: 310-318.

LEE, J., KOSINSKI, P. A., KEMP, D. M. (2005). Contribution of human bone marrow stem cells to individual skeletal myotubes followed by myogenic gene activation. Exp Cell Research, 307: 174-182.

LIN, Y., LIU, L., LI., Z., QIAO, J., WU, L., TANG, W., ZHENG, X., CHEN, X., YAN, Z., TIAN, W. (2006). Pluripotency potential of human adipose-derived stem cells marked with exogenous green fluorescent protein. Mol. Cell. Bioch., DOI: 10.1007/s11010006-9188-5.

LIU, H., JAN, M. CHOU, C., CHEN, P., KE,N. (1999). Is fluorescent protein toxic to the living cells? Bioch Biophy Res Comminic, 260: 712-717.

MIMEAUlT, M., HAUKE, R., BATRA, S. K. (2007). Stem Cells: A revolution in therapeutics - Recent advances in stem cell biology and their therapeutic applications in regenerative medicine and cancer therapies. Nature, 83 (3): 252-264.

MINGUELL, J. J., CONGET, P., ERICES, A. (2000). Biology and clinical utilization of mesenchymal progenitor cells. Braz J Med Biol Res, 33: 881-887. 
MULLER, J., VAYSSIERE, N., ROYUELA, M., LEGER, M. E., MULLER, A., BACOU, F., PONS F., HUGON, G., MORNET, D. (2001). Comparative evolution of muscular dystrophy in diaphragm, gastrocnemius and masseter muscles from old male mdx mice. J Muscle Res Cell Motil, 22(2): 133-139.

MUNTONI, F., BROWN, S., SEWRY, C., PATEL, K. (2002). Muscle development genes: their relevance in neuromuscular disorders. Neuro Dis, 12: 438-446.

NAWROTZKI, R., BLAKE, D. J., DAVIES, K. E. (1996). The genetic basis of the neuromuscular disorders. TIG, 12(8): 294-298.

NUNES, V. A., CAVACANA, N., CANOAS, M., STRAUSS, B. E., ZATZ, M. (2007). Stem cells from umbilical cord blood differentiate into myotubes and express dystrophin in vitro only after exposure to in vivo muscle environment. Biol. Cell., 99(4): 185-196.

OHLENDIECK, K. \& CAMPBELL, K. P. (1991). Dystrophin-associated proteins are greatly reduced in skeletal muscle from mdx mice. J Biol Chem, 273:5419-5422.

OKABE, M., IKAWA M., KOMINAMI, K., NAKANISHI, T., NISHIMUNE, Y. (1997). 'Green mice' as a source of ubiquitous green cells. FEBS Letters, 407: 313-319.

PASTORET, C. \& SEBILLE, A. (1995). Mdx mice show progressive weakness and muscle deterioration with age. J Neurol Sci, 129: 97-105.

PEREIRA, R. F., HALFORD, K. W., O`HARA, M. D., LEEPER, D. B., SOKOLOV, B. P., POLLARD, M. D., BAGASRA, O., PROCKOP, D. J. (1995). Cultured adherent cells from marrow can serve as long-lasting precursor cells for bone, cartilage, and lung in irradiated mice. Proc Natl Acad Sci USA, 92: 4857-4861. 
PITTENGER, M. F., MACKAY, A. M., BECK, S. C., JAISWAL, R. K., DOUGLAS, R., MOSCA, J. D., MOORMAN, M. A., SIMONETTI, D. W., CRAIG, S., MARSHAK, D. A. (1999). Multilineage potential of adult mesenchymal stem cells. Science, 284: 143147.

POUNTOS, I. \& GIANNOUDIS, P. V. (2005). Biology of mesenchymal stem cells. Int J Care Injured, 365: S8-S12.

PROCKOP, D. J. (1997). Marrow stromal cells as stem cells for nonhematopoietic tissues. Science, 276: 71-74.

RAFAEL, J. A. \& BROWN, S. C. (2000). Dystrophin and utrophin: genetic analyses of their role in skeletal muscle. Microsc Res Tech, 48: 155-166.

RE, F., SRINIVASAN, R., IGARASHI, T., MARINCOLA, F., CHILDS, R. (2004). Green fluorescent protein expression in dendritic cells enhances their immunogenicity and elicits specific cytotoxic T-cell responses in humans. Experimental Hematology, 32: $210-217$.

REIMANN, J., IRINTCHEV, A., WERNIG, A. (2000). Regenerative capacity and the number of satellite cells in soleus muscles of normal and mdx mice. Neuro Disord, 10: 276-282.

REUBINOFF, B. E., PERA, M. F., FONG, C., TROUNSON, A., BONGSO, A. (2000). Embryonic stem cell lines from human blastocysts: somatic differentiation in vitro. Nature Biotechnology, 18: 399-404.

RIPPON, H. J. \& BISHOP, A. E. (2004). Embryonic stem cells. Cell Prolif, 37: 23-34. 
ROHWEDEL, J., MALTSEV, V., BOBER, E., ARNOLD, H. H., HERCHELER, J., WOBUS, A. M. (1994). Muscle cell differentiation of embryonic stem cells reflects myogenesis in vivo: developmentally regulated expression of myogenic determination genes and functional expression of ionic currents. Dev. Biol., 164: 87-101.

ROSENZWEIG, M., CONNOLE, M., GLICKMAN, R., YUE, S. S., NOREN B., DEMARIA, M., JOHNSON, R. P. (2001). Induction of cytotoxic T lymphocyte and antibody responses to enhanced green fluorescent protein following transplantation of transduced CD34+ hematopoietic cells. Blood, 97: 1951-1959.

SAMPAOLESI, M., BLOT, S., D’ANTONA, G., GRANGER, N., TONLORENZI, R., INNOCENZI, A., MOGNOL, P., THIBAUD, J., GALVEZ, B. G., BARTHÉLÉMY, I., PERANI, L., MANTERO, S., GUTTINGER, M., PANSARASA, O., RINALDI, C., DE ANGELIS, M. G. C., TORRENTE, Y., BORDIGNON, C., BOTTENELLI, R., COSSU, G. (2006). Mesoangioblast stem cells ameliorate muscle function in dystrophic dogs. Nature, doi: 10.1038/nature05282.

SEALE, P. \& RUDNICKI, M. A. (2000). A new look at the origin, function, and "stem-cell" status of muscle satellite cells. Dev Bio, 218: 115-124.

STRIPECKE, R., CARMEN VILLACRES, M., SKELTON, D., SATAKE, N., HALENE, S., KOHN, D. (1999). Immune response to green fluorescent protein: implications for gene therapy. Gene Ther., 6 (7):1305-1312.

THOMSON, J. A., ITSKOVITZ-ELDOR, J., SHAPIRO, S. S., WAKNITZ, M. A., SWIERGIEL, J. J., MARSHALL, V. S., JONES, J. M. (1998). Embryonic stem cell lines derived from human blastocysts. Science, 282:1145-1147.

UTERMÖHLEN, O. \& KRÖNKE, M. (2007). Survival of priceless cells: Active and passive protection of embryonic stem cells against immune destruction. Archives of Biochemistry and Biophysics, 462: 273 - 277. 
VAINZOF, M., ZUBRZYCKA-GAARN, E. E., RAPAPORT, D., PASSOS-BUENO, M. R., PAVANELLO, R. C. M., PAVANELLO, I., ZATZ, M. (1991). Immunofluorescence dystrophin study in Duchenne dystrophy through the concomitant use of two antibodies directed against the carboxy-terminal and the amino-terminalregion of the protein. $\mathbf{J}$ Neurol Sci, 101: 141-147.

VAINZOF, M. \& ZATZ, M. (2003). Protein defects in neuromuscular diseases. Braz J Med Biol Res., 36 (5): 543-55.

VERELlEN-DUMOUlin, C. H., FREUND, M., DE MEYER, R., LATERRE, C. H., FREDERIC, J., THOMPSON, M. W., MARKOVIC, V. D., WORTON, R. G. (1984). Expression of an X-linked muscular dystrophy in a female due to translocation involving Xp21 and non-random inactivation of the normal X chromosome. Hum. Genet., 67: 115-119.

WAKITANI, S., SAITO, T., CAPLAN, A. I. (1995). Myogenic cells derived from rat bone marrow mesenchymal stem cells exposed to 5-azacytidine. Muscle Nerve, 18: 1417 1426.

WEISS, A. \& LEINWAND, L. A. (1996). The mammalian myosin heavy chain gene family. Annu Rev Cell Dev Biol, 12: 417-439.

WOBUS, A. M., GUAN, K., YANG, H., BOHELER, K. (2002). Embryonic Stem Cells as a model to study cardiac, skeletal muscle and vascular smooth muscle cell differentiation. Methods in Molecular Biology, 185: 127-156.

WU, D. C., BOYD, A. S., WOOD, K. J. (2007). Embryonic stem cell transplantation: potential applicability in cell replacement therapy and regenerative medicine. Frontiers in Bioscience, 12: 4525-4535. 
ZATZ, M., VIANNA-MORGANTE, A. M., CAMPOS, P., DIAMENT, A. J. (1981). Translocation $(\mathrm{X} ; 6)$ in female with Duchenne muscular dystrophy: implications for the localizations of the DMD locus. J. Med. Gen., 18 (6): 442-447.

ZATZ, M., VAINZOF, M., PASSOS-BUENO, M. R. (2000). Limb-girdle muscular dystrophy: one gene with different phenotypes, one phenotype with different genes. Curr. Opin. Neurol., 13 (5): 511-517.

ZATZ, M. Distrofias Musculares Prograssivas. In: CARAKUSHANSKY, G., ed. Doenças genéticas em pediatria. Rio de Janeiro, Guanabara - Koogan, 2001. p. 245-260.

ZUBRZYCKA-GAARN, E. E., BULMAN, D. E., KARPATI, G., BURGHES, A. H., BElfAll, B., KLAMUT, H. J., TAlBOT, J., HODGES, R. S., RAY, P. N., WORTON, R. G. (1988). The Duchenne muscular dystrophy gene product is localized in sarcolemma of human skeletal muscle. Nature, 333: 466-469. 